\title{
PARTICLE-TRACKING ANALYSIS OF CONTRIBUTING AREAS OF PUBLIC-SUPPLY WELLS IN SIMPLE AND COMPLEX FLOW SYSTEMS, CAPE COD, MASSACHUSETTS
}

U.S. GEOLOGICAL SURVEY

Open-File Report 93-159

$$
19942
$$

Prepared in cooperation with the

MASSACHUSETTS DEPARTMENTS OF ENVIRONMENTAL

MANAGEMENT AND ENVIRONMENTAL PROTECTION, and

THE CAPE COD COMMISSION

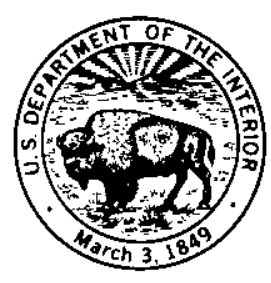




\section{PARTICLE-TRACKING ANALYSIS OF CONTRIBUTING AREAS OF PUBLIC-SUPPLY WELLS IN SIMPLE AND COMPLEX FLOW SYSTEMS, CAPE COD, MASSACHUSETTS}

By Paul M. Barlow

U.S. GEOLOGICAL SURVEY

Open-File Report 93-159

Prepared in cooperation with the

MASSACHUSETTS DEPARTMENTS OF ENVIRONMENTAL

MANAGEMENT AND ENVIRONMENTAL PROTECTION,

and THE CAPE COD COMMISSION

Marlborough, Massachusetts

1994 


\title{
U.S. DEPARTMENT OF THE INTERIOR BRUCE BABBITT, Secretary
}

\author{
U.S. GEOLOGICAL SURVEY \\ GORDON P. EATON, Director
}

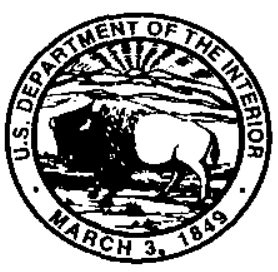

Any use of trade, product, or firm names in this publication is for descriptive purposes only and does not imply endorsement by the U.S. Government.

For sale by the

U.S. Geological Survey

Earth Science Information Center

Open-File Reports Section

Box 25286, MS 517

Denver Federal Center

Denver, CO 80225

For additional information write to:

Chief, Massachusetts-Rhode Island District

U.S. Geological Survey

Water Resources Division

28 Lord Road, Suite 280

Marlborough, MA 01752 


\section{CONTENTS}

Abstract

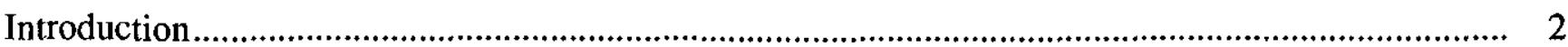

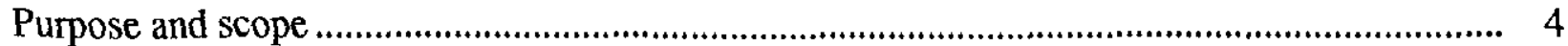

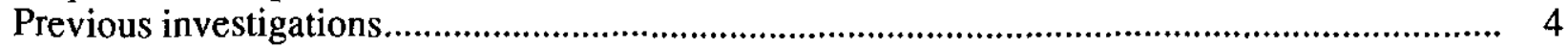

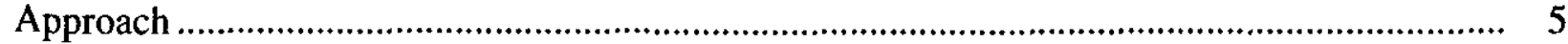

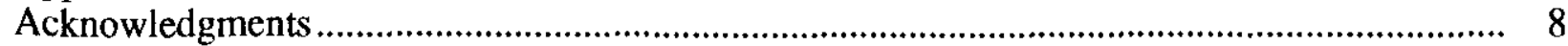

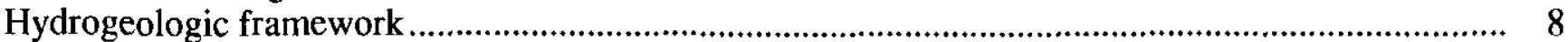

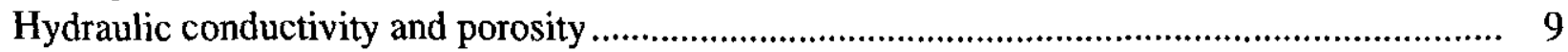

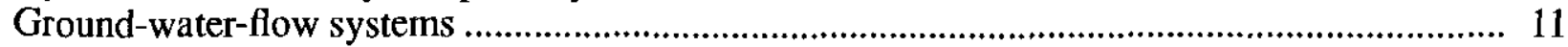

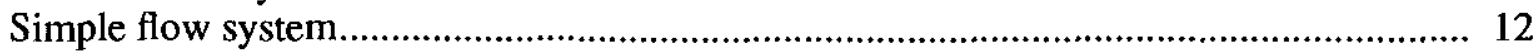

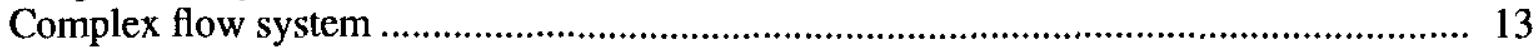

Numerical models of ground-water flow used in particle-tracking analysis ................................. 14

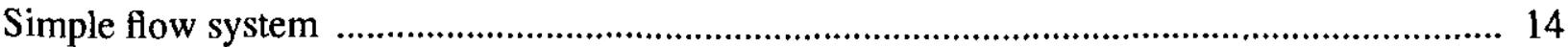

Conceptual model of ground-water flow .................................................................. 14

Three-dimensional model ............................................................................................. 16

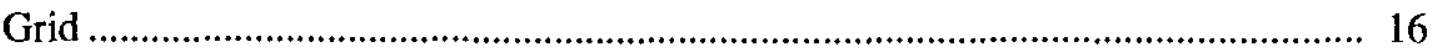

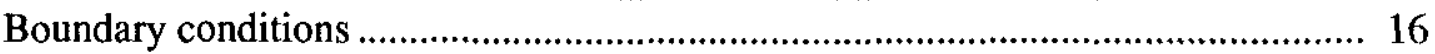

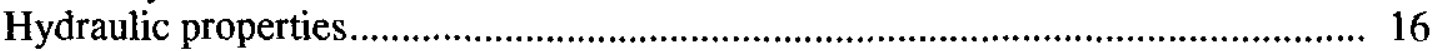

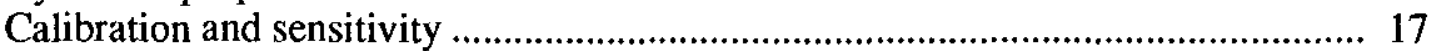

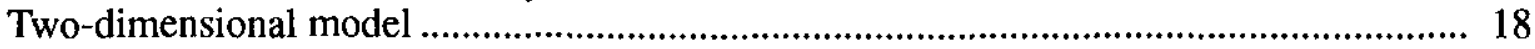

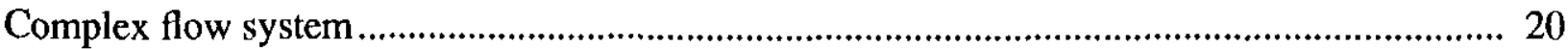

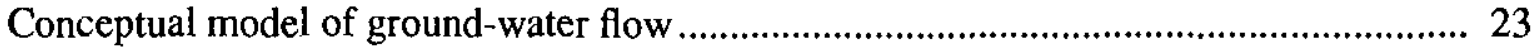

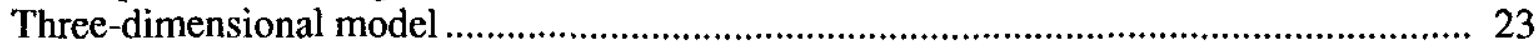

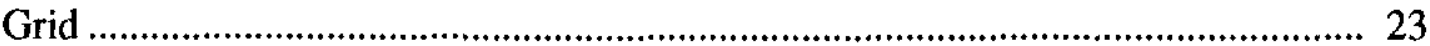

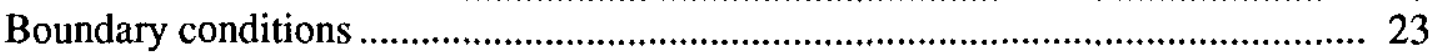

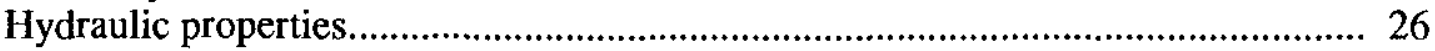

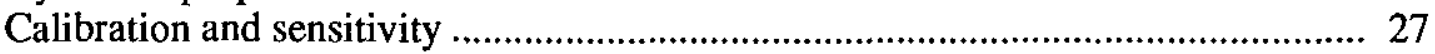

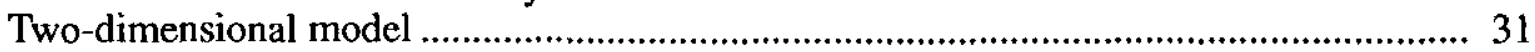

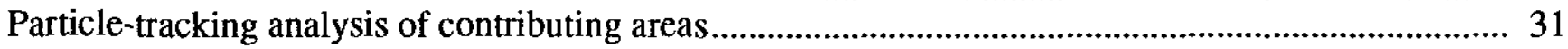

Procedure for delineation of contributing areas ........................................................ 34

Simple flow system—analysis of contributing areas to two hypothetical wells ....................... 35

Delineation of contributing areas for a pumping rate of 0.5 million

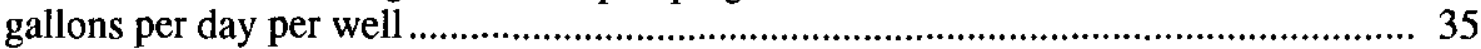

Sensitivity of contributing areas to selected factors ................................................. 38

Penetration of well screens, pumping rates of wells, and ratio of horizontal to vertical hydraulic conductivity .............................................. 38

Parameter uncertainty: horizontal hydraulic conductivity, recharge,

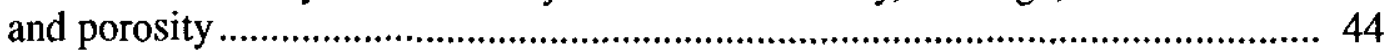

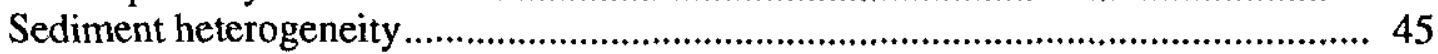

Vertical discretization of flow model ............................................................... 47

Complex flow system-analysis of contributing areas to existing wells................................. 48

Delineation of contributing areas for 1987 average daily pumping rates........................ 48

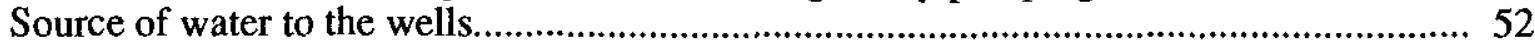

Sensitivity of contributing areas to selected factors ................................................... 55 
Hydraulic conductivity of fine-grained sediments of eastern Barnstable ............... 56

Distribution of wastewater return flow ................................................................. 56

Pond depth and vertical hydraulic conductivity of pond-bottom sediments............ 57

Vertical discretization of flow model ............................................................... 58

Data requirements for and limitations of particle tracking for delineation of

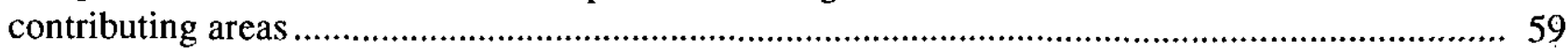

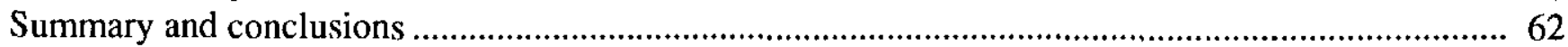

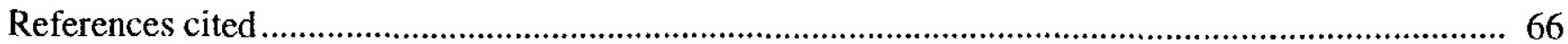

\section{FIGURES}

Figures 1-5. Maps showing:

1. Water-table configuration on May 25-27, 1976 and locations of simple and complex flow systems, Cape Cod, Massachusetts

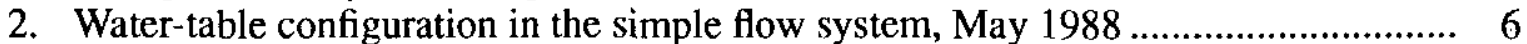

3. Water-table configuration in the complex flow system, October $14,1987 \ldots \ldots \ldots \ldots \ldots . . . .7$

4. Model grid and lateral boundary conditions for the two-dimensional flow model and the top layer of the three-dimensional flow model of the simple flow system....

5. Calculated water-table configurations for $(A)$ the top layer of the three-dimensional model and $(B)$ the two-dimensional model of the simple flow system.

6. Graphs showing sensitivity of the three-dimensional model of the simple flow system to changes in $(A)$ recharge and horizontal hydraulic conductivity of the top layer of the model and $(B)$ vertical conductance of layer 1 and transmissivity of layer 5 , and $(C)$ sensitivity of the two-dimensional model of the simple flow system to changes in recharge and horizontal hydraulic conductivity

7. Graph showing mean residuals between observed and calculated heads resulting from simultaneous changes to recharge and hydraulic conductivity of layer 1 of the three-dimensional flow model for the simple flow system.

8. Map showing model grid and lateral boundary conditions for the three- and two-dimensional models of the complex flow system.

9. Map showing calculated water-table configuration for the top layer of the three-dimensional model of the complex flow system.

10. Graphs showing sensitivity of $(A)$ the three-dimensional model and $(B)$ the two-dimensional model of the complex flow system to changes in recharge and horizontal hydraulic conductivity of layer 1 of each model.

11. Map showing calculated water-table configuration for the two-dimensional model of the complex flow system

12. Map showing contributing areas of and traveltimes to wells $\mathrm{A}$ and $\mathrm{B}$ for a pumping rate of 0.5 million gallons per day per well, determined by use of the three-dimensional model of the simple flow system.

13. Diagrams showing particle pathlines in row 55 of the three-dimensional model of the simple flow system: $(A)$ after 5 years of travel, $(B)$ after 10 years of travel, and

$(C)$ for steady-state distribution of pathlines.

14. Maps showing contributing areas of wells $\mathrm{A}$ and $\mathrm{B}$ for well screens located in $(A)$ layer $1,(B)$ layer 2 , and $(C)$ layer 3 of the three-dimensional model of the simple flow system, at a pumping rate of 0.1 million gallons per day per well 
15. Maps showing contributing areas of wells A and B from simulation in which the vertical conductance of layers 1 through 3 of the three-dimensional model of the simple flow system is reduced by $(A)$ one order of magnitude and $(B)$ two orders of magnitude

16. Diagrams showing particle pathlines in row 55 of the three-dimensional model of the simple flow system from $(A)$ simulation of the natural system, $(B)$ simulation in which the vertical conductance of the top two layers is reduced by two orders of magnitude, and $(C)$ simulation of a lens of low hydraulic conductivity near well B

17-22. Maps showing:

17. Contributing areas of wells $\mathrm{A}$ and $\mathrm{B}$ in the simple flow system for $(A)$ recharge rate equal to 80 percent of the calibrated-model value and horizontal hydraulic conductivity of layer 1 of the three-dimensional model equal to 70 percent of the calibrated-model value and $(B)$ recharge rate equal to 120 percent of the calibrated-model value and horizontal hydraulic conductivity of layer 1 of the three-dimensional model equal to 130 percent of the calibrated-model value

18 Contributing areas of wells A and B from simulation of $(A)$ a continuous zone and $(B)$ discontinuous zones of low hydraulic conductivity near well B, determined by use of the three-dimensional model of the simple flow system.

19. Contributing areas of wells $\mathrm{A}$ and $\mathrm{B}$ for a pumping rate of 0.5 million gallons per day per well by use of $(A)$ the three-dimensional and $(B)$ the two-dimensional model of the simple flow system.

20. Contributing areas of 15 public-supply wells in the complex flow system.

21. Contributing areas of wells BWC-HY and BWC-SI and of ponds that are within the contributing areas of these wells for 1987 average daily pumping rates, determined by use of the three-dimensional model of the complex flow system.

22. Contributing areas of wells CO-7, CO-8, and CO-11 for 1987 average daily pumping rates, determined by use of the three-dimensional model of the complex flow system.

23. Graph showing calculated percentage of well discharge from septic systems, determined by use of the three-dimensional model of the complex flow system, and nitrate concentrations in water from the wells in 1987

24-26. Maps showing:

24. Contributing areas of six public-supply wells from simulation of a reduction in the hydraulic conductivity of fine-grained sediments of eastern Barnstable, determined by use of the three-dimensional model .

25. Contributing areas of six public-supply wells from simulation of a redistribution of wastewater return flow from septic systems to the wastewater-treatment facility in the complex flow system, determined by use of the three-dimensional model.

26. Contributing areas of seven public-supply wells in the complex flow system for 1987 average daily pumping rates, determined by use of the two-dimensional model. 


\section{TABLES}

Page

Table 1. Particle-size distributions of cored samples from the simple and complex flow systems and hydraulic conductivity of cored samples from the simple flow system on Cape Cod, Massachusetts.....

2. Hydraulic conductivity of stratified drift at selected well locations on Cape Cod, Massachusetts.

3. Hydraulic conductivity for glacial sediments of Cape Cod, Massachusetts, generalized from tables 1 and 2

4. Vertical layering, horizontal hydraulic conductivity, and vertical conductance of the calibrated three- and two-dimensional flow models of the simple flow system.

5. Observed heads and heads calculated by the three- and two-dimensional models of the simple flow system

6. Vertical layering, horizontal hydraulic conductivity, and vertical conductance of the calibrated three- and two-dimensional flow models of the complex flow system.... 25

7. Pumping rates measured on October 14, 1987, for 12 public-supply wells in Barnstable and Yarmouth, Massachusetts

8. Observed heads and heads calculated by the three- and two-dimensional models of the complex flow system.

9. Calculated water budgets for the three- and two-dimensional flow models of the complex flow system.

10. Summary of hydrogeologic and model conditions for delineation of contributing areas of hypothetical wells A and B in the simple flow system.

11. Traveltime of particles from the water table to hypothetical wells A and B in the simple flow system.

12. Average daily pumping rates in 1987 for wells simulated in the models of the complex flow system.

13. Specified pumping rates and pumping rates calculated by use of the three-dimensional model for selected wells in the complex flow system

14. Amount of pond throughflow to selected wells in the complex flow system, as a percentage of well pumping rates

15. Size of contributing areas of selected wells in the complex flow system, determined by use of the three-dimensional model

16. Calculated captured wastewater from septic-system and treatment-facility sources as a percentage of well pumping rate, and measured nitrate concentrations in water samples from selected wells in the complex flow system, 1987

17. Specified pumping rates and pumping rates calculated by use of the two-dimensional model for selected wells in the complex flow system. 


\section{CONVERSION FACTORS, VERTICAL DATUM, AND ABBREVIATED WATER-QUALITY}

UNITS

\begin{tabular}{rcl} 
Multiply & By & To obtain \\
\hline acre & 4,047 & square meter \\
cubic foot per second $\left(\mathrm{ft}^{3} / \mathrm{s}\right)$ & 0.02832 & cubic meter per second \\
cubic foot per day $\left(\mathrm{ft}^{3} / \mathrm{d}\right)$ & 0.02832 & cubic meter per day \\
cubic foot per second per & & cubic meter per second \\
square mile $\left[\left(\mathrm{ft}^{3} / \mathrm{s}\right) / \mathrm{mi}^{2}\right]$ & foot $(\mathrm{ft})$ & per square kilometer \\
inch $(\mathrm{in})$. & 0.01093 & meter \\
mile $\left(\mathrm{mi}^{2}\right)$ & 25.4 & millimeter \\
square mile $\left(\mathrm{mi}^{2}\right)$ & 1.609 & kilometer \\
gallon $(\mathrm{gal})$ & 2.590 & square kilometer \\
million gallons per day $(\mathrm{Mgal} / \mathrm{d})$ & 3.785 & liter \\
inches per year $(\mathrm{in} / \mathrm{yr})$ & 0.04381 & cubic meter per second \\
foot per day $(\mathrm{ft} / \mathrm{d})$ & 25.4 & millimeter per year \\
times foot of aquifer thickness & 0.3048 & meter per day \\
$\left[\left(\mathrm{ft}^{3} / \mathrm{d}\right) / \mathrm{ft}^{2}\right] \mathrm{ft}$ (reduces to $\left.\mathrm{ft}^{2} / \mathrm{d}\right)$ & & cubic meter per day per \\
cubic foot per day per square foot & 0.09290 & of aquifer thickness
\end{tabular}

Nitrate concentrations are given in $\mathrm{mg} / \mathrm{L}$ (milligrams per liter). Density is reported in $\mathrm{gm} / \mathrm{cm}^{3}$ (grams per cubic centimeter).

Sea level: In this report, "sea level" refers to the national geodetic Vertical Datum of 1929 (NGVD of 1929)-- a geodetic datum derived from a general adjustment of the first-order level nets of the United States and Canada, formerly called the Sea Level Datum of 1929. 


\title{
Particle-Tracking Analysis of Contributing Areas of Public-Supply Wells in Simple and Complex Flow Systems, Cape Cod, Massachusetts
}

\author{
By Paul M. Barlow
}

\section{Abstract}

Steady-state, two- and three-dimensional, finitedifference ground-water-flow models coupled with particle tracking were evaluated to determine their effectiveness in delineating contributing areas of existing and hypothetical public-supply wells pumping from two different flow systems of Cape Cod, Mass. The flow systems represent the range of hydrogeologic complexity of flow systems of Cape Cod and are typical of shallow, highly permeable stratified-drift aquifers. The first flow system (the simple flow system) consists of a thin (up to 100 feet thick), single-layer aquifer with nearideal boundary conditions and no large-capacity publicsupply wells. The second flow system (the complex flow system) consists of a thick (approximately 250 to 500 feet), multilayered aquifer with non-ideal boundary conditions (including streams, ponds, and spatial variability of recharge rates) from which 32 partially penetrating public-supply wells currently (1987) pump water. Analytical methods previously used to delineate contributing areas to wells of Cape Cod were found to be incapable of accounting for all of the hydrogeologic and well-design characteristics that affect the delineation of contributing areas, including spatial variability of recharge, aquifer heterogeneity, non-ideal boundary conditions, and multiple, partially penetrating supply wells.

Results of the investigation indicate that the choice of either a two- or a three-dimensional model for delineation of contributing areas depends largely on the complexity of the flow system tapped by the well. Contributing areas delineated for hypothetical wells in the simple flow system were not significantly different for the two- or three-dimensional models of the natural system at pumping rates greater than or equal to 0.25 million gallons per day. For this relatively thin, singlelayer aquifer with near-ideal boundary conditions, the use of a three-dimensional model to delineate contributing areas of supply wells may not be warranted. Several of the contributing areas delineated by use of the threedimensional model of the complex flow system and by use of the three-dimensional model of the simple flowsystem for hypothetical conditions, however, did not conform to simple ellipsoidal shapes that are typically delineated by use of two-dimensional analytical and numerical modeling techniques, included discontinuous areas of the water table, and did not surround the wells. Because two-dimensional areal models do not account for vertical flow, they cannot adequately represent many of the hydrogeologic and well-design characteristics that were shown to complicate the delineation of contributing areas in these systems, including the presence and continuity of discrete lenses of low hydraulic conductivity, ratios of horizontal to vertical hydraulic conductivity greater than the stratified-drift aquifers, shallow streams, partially penetrating supply wells, low (less than about $0.1 \mathrm{Mgal} / \mathrm{d}$ ) pumping rates, and spatial variability of recharge rates. Under these conditions, accurate delineation of contributing areas may require the use of a three-dimensional model.

Particle tracking helped identify the source of water to simulated wells. In the simple flow system, precipitation recharge was the only source of water to the wells. The size of the contributing area of each well in this flow system is equal to the pumping rate of the well divided by the uniform recharge rate to the aquifer within the contributing areas of the wells. In the complex flow system, precipitation recharge, wastewater return flow, and pond throughflow were the predominant sources of water to the wells. Pond throughflow and wastewater return flow accounted for up to 73 and 40 percent of well discharge, respectively. Contributing areas in the complex flow system are not linearly related to the pumping rate at each well because of the inclusion of ponds and pond contributing areas within the contributing areas to wells, and because recharge rates to the aquifer are spatially variable. Elevated nitrate (as nitrogen) concentrations, an indicator of contamination from septic systems and wastewater-treatment facilities, were 
found in wells for which estimates of the volume of captured wastewater were large; this pattern indicates a correlation between the quality of water discharged by the wells and the simulated source of water to the wells.

Although particle tracking was shown to be of value in the delineation of contributing areas in simple and complex flow systems, the method requires a large amount of data, which must be collected and analyzed, especially for three-dimensional simulations. In addition, several limitations of the method affect the accuracy with which a contributing area can be defined. These limitations include those caused by uncertainty in the definition of boundary conditions, stresses, and model parameters; limitations caused by discretization of the flow system by a finite-difference grid; and limitations in the data base used for model calibration. Contributing areas of several wells in the complex flow system were affected by the scale of discretization used to represent internal boundary sinks (such as wells, streams, and lakes). Internal boundary sinks affected contributing areas delineated by use of the two-dimensional model more than those delineated by use of the three-dimensional model because the single-layer model does not adequately represent the vertical location of the screened interval of supply wells or the location of shallow streams and lakes. Nevertheless, accurate flow simulation coupled with particle tracking provides a technically rigorous and defensible means of delineating contributing areas of supply wells for the purpose of wellhead protection.

\section{INTRODUCTION}

The degradation of ground-water quality caused by human activities can have profound effects on the health and economic viability of communities that depend on ground water for their domestic, industrial, and agricultural needs. Protection of ground-water resources is therefore becoming an integral part of State and Federal strategies for continued maintenance of the quality of public water supplies. To protect ground water pumped by public-supply wells, Congress established the Wellhead Protection Program through the 1986 amendments to the Safe Drinking Water Act of 1974. As part of these amendments, States are required to determine the land area that contributes water to public-supply wells within their jurisdiction and to enact programs to prevent contamination of ground-water resources underlying these areas. The land area that contributes water to a supply well has been referred to as the "wellhead protection area", "contributing area", "recharge area", or the "capture zone" of a well. In this report, the term "contributing area" is used. The term wellhead-protection area is not used here because it implies a regulatory aspect to the contributing area, and its boundaries may be different from the actual physical boundaries of the land area that contributes water to a well. The term "recharge area" is traditionally used to refer to the land area that recharges an aquifer. Empirical, analytical, and numerical methods available for delineation of the contributing area of a well typically do not adequately account for several of the characteristics and conditions that affect flow of water to a well, including aquifer heterogeneity; spatial variability of recharge rates; non-ideal boundary conditions; and multiple, partially penetrating supply wells with variable discharge rates. Because these methods cannot account for all of these characteristics and conditions, the accuracy with which contributing areas is defined is often questionable, and the quality of water pumped by supply wells therefore may be adversely affected.

The development of particle-tracking algorithms that track fuid-particle pathlines within numerical flow models has increased the hydrologist's ability to analyze ground-water-flow systems quantitativcly. Particle tracking allows for delineation of the contributing area of a well because particles can be tracked from areas of ground-water recharge to a discharging well, thereby identifying the area contributing water to a well. Numcrical modeling coupled with particle tracking is an improvement over analytical methods and twodimensional flow-net analyses because particles can be tracked in complicated, two- and three-dimensional flow systems. Although two-dimensional flow-net analyses may be useful for simple, two-dimensional flow systems, the construction of a two-dimensional flow net for a three-dimensional flow system is a time-consuming task that can yield inaccurate results because it is necessary to disregard flow in the third dimension. Particle tracking offers a relatively simple, yet quantitatively powerful, alternative to the construction of ground-water flow nets for delineation of contributing areas and sources of water to public-supply wells.

The ground-water-flow system of Cape Cod, Mass. (fig. 1) is typical of shallow, highly permeable, stratifieddrift aquifers susceptible to contamination from 


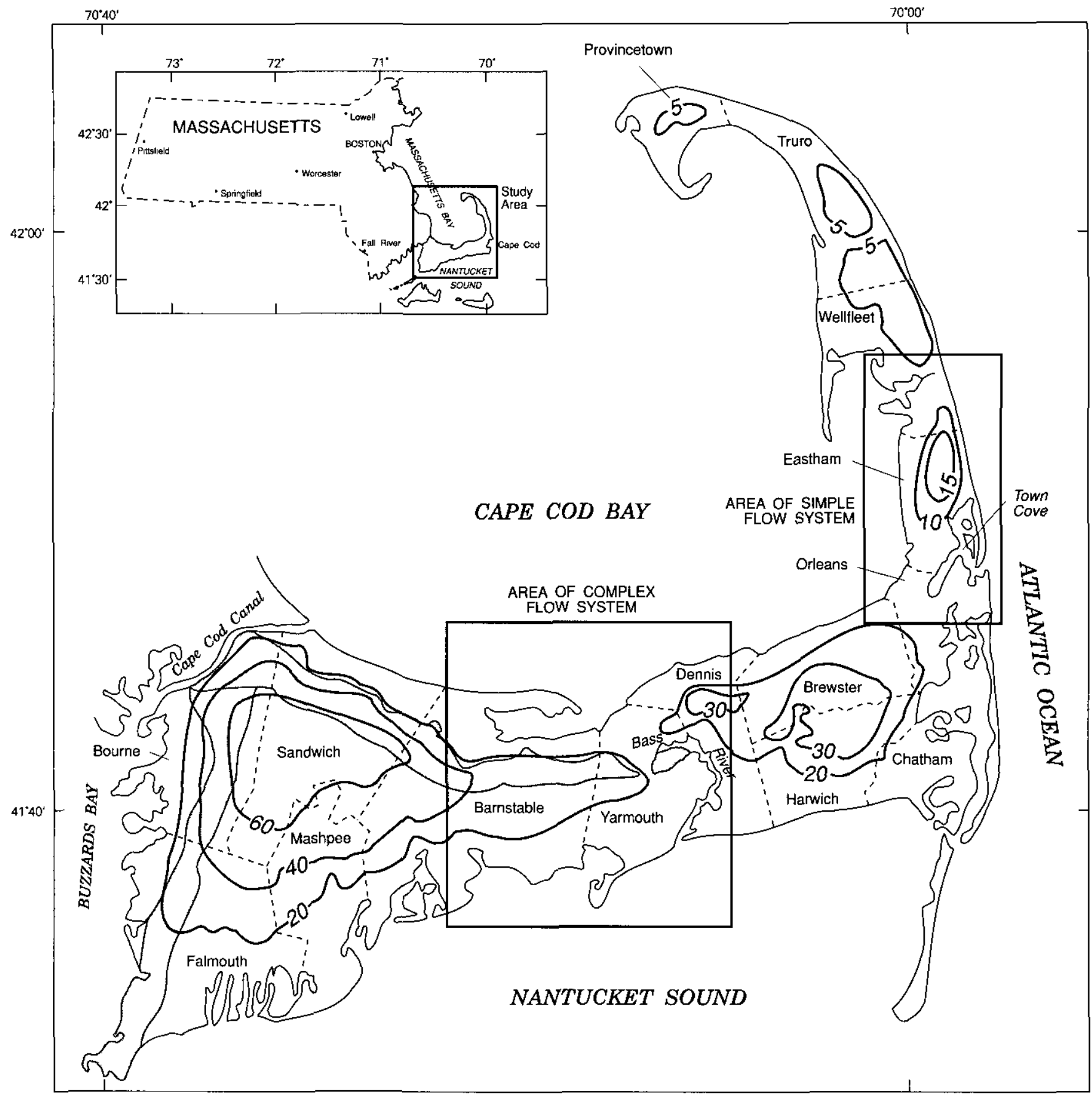

Base from U.S. Geological Survey

$1: 500,000$ State base map.

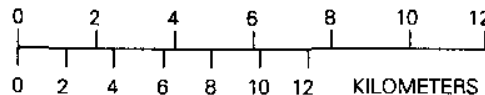

MILES

EXPLANATION

AREA OF GLACIAL MORAINE

WATER-TABLE CONTOUR--Shows altitude of water table. Contour interval, in feet, is variable. Datum is sea level.

Figure 1. Water-table configuration on May 25-27, 1976, and locations of simple and complex flow systems, Cape Cod, Massachusetts. 
domestic, industrial, and agricultural sources. Nearly 200 public-supply wells pump water from the glacial deposits of Cape Cod. Many of these wells withdraw water from only a small part of the aquifer (that is, they partially penetrate the aquifer), are near ponds and other surface-water bodies, and withdraw water from beneath semiconfining deposits. A recent analysis of contributing areas delineated for public-supply wells of Cape Cod made by the Aquifer Assessment Committee of the Cape Cod Aquifer Management Project (1988) indicated that analytical-modeling techniques that had been used for delineation of the contributing areas of the wells could not account for all of the complex hydrogeologic interrelations that are present in many parts of the ground-water-flow system of Cape Cod. Consequently, it was recommended that a study be done to demonstrate the use and to assess the effectiveness and limitations of numerical modeling coupled with particle tracking for delineation of contributing areas to publicsupply wells of Cape Cod (Aquifer Assessment Committee, Cape Cod Aquifer Management Project, 1988, p. F-3). The investigation was done during $1987-90$ by the U.S. Geological Survey (USGS), in cooperation with the State of Massachusetts, Departments of Environmental Management and Environmental Protection, and with the Cape Cod Commission.

\section{Purpose and Scope}

This report presents the results of a study to demonstrate the use of and to assess the effectiveness and limitations of numerical-flow modeling coupled with particle tracking for delineation of contributing areas for existing and hypothetical supply wells pumping from stratified-drift aquifers of Cape Cod, Mass. Two different ground-water-flow systems of Cape Cod were chosen for investigation. These flow systems represent the range of hydrogeologic complexity of Cape Cod. The first flow system (referred to in the report as the "simple flow system") consists of a thin, single-layer aquifer with near ideal boundary conditions and no large-capacity public-supply wells. The simple flow system is in the towns of Eastham and Wellficet (fig. 2). The second flow system (referred to in the report as the "complex flow system") is a thick, multilayer aquifer with non-ideal boundary conditions (including streams, ponds, and spatial variability of recharge rates) and 32 public-supply wells. The complex flow system is in the towns of Barnstable and Yarmouth (fig. 3).
Steady-state, two- and three-dimensional groundwater-flow models were developed for each system to compare and contrast contributing areas delineated by use of each of the two vertical-layering schemes. These models were based on available hydrogeologic and well-design data and a conceptual model of groundwater flow in each system. Contributing areas of hypothetical and existing wells were delineated by particletracking analyses ${ }^{1}$. The effect of several well-design and hydrogeologic factors--such as well location and pumping rate, aquifer heterogeneity, spatial variability of recharge rates, and parameter uncertainty with regard to location, shape, and size of contributing areas-was investigated by use of sensitivity analyses in which the values of the factors were varied. Sources of water to the supply wells were identified and quantified as part of the particle-tracking analysis. Data requirements for and limitations of particle tracking for delineation of contributing areas were evaluated with specific reference to the two flow systems.

\section{Previous Investigations}

The dynamics of ground-water flow associated with the response of an aquifer to pumping and of the related concepts of contributing areas of supply wells have been discussed previously by Meinzer (1923), Theis (1938), Brown (1963), and Morrissey (1989), among others. The use of particle tracking for the delineation of supply-well contributing areas is relatively new; however, analytical methods and two- and three-dimensional numerical models have been widely applied in the analysis of supply-well contributing areas. The following paragraphs present a short synopsis of previous investigations in which analytical modeling, numerical modeling, and particle tracking have been used to delineate contributing areas.

Most analytical methods require that simplifying assumptions be made about the ground-water system from which a well pumps and about the geometry of the well itself. These assumptions include simplifications or idealizations of aquifer boundary conditions, homogeneity of aquifer properties (such as hydraulic conductivity),

\footnotetext{
${ }^{1}$ Because ground-water velocities must be computed by means of a numerical ground-water-flow model before a particletracking analysis, references to particle tracking in the report imply the development of a numerical ground-water-flow model and the tracking of fluid particles within that model.
} 
and simplification of well design (such as a fully penetrating well screen). These models and assumptions are discussed by Keely and Tsang (1983), Lee and Wilson (1986), Javandal and Tsang (1986), Wilson (1986), U.S. Environmental Protection Agency (1987), Heijde and Beljin (1988), Newsom and Wilson (1988), Vecchioli and others (1989), Morrissey (1989), Linderfelt and others (1989), and Bair and others (1991).

An analytical model was used by the Cape Cod Planning and Economic Development Commission (Horsley, 1983) to delineate contributing areas of public-supply wells on Cape Cod. Estimates of transmissivity, specific yield, and projected pumping rates were used to develop a distance-drawdown relation for each well. Computed drawdowns were superimposed on the regional water table. The stagnation point of each contributing area was computed as the point downgradient from the well at which the calculated drawdowns were unable to reverse the natural flow direction of the ground water toward the well. Each contributing area then was extended upgradient from the stagnation point along lines drawn perpendicular to the water-table altitudes to a point that was equal to one-third the distance between the well and the regional ground-water-flow divide. The contributing area was assumed to be equal to the discharge rate of the well divided by the recharge rate to the aquifer, assumed to be $13 \mathrm{in} / \mathrm{yr}$. Contributing areas of several wells in the complex flow system delineated by Horsley's method are compared to those delineated by the particle-tracking method later in the report.

Numerical ground-water-flow models have been used extensively for the conceptual and quantitative analysis of ground-water flow, including the delineation of contributing areas of public-supply wells. Numerical models are used to determine heads at specified locations within a simulated aquifer. Ground-water flow nets then are constructed from these heads to delineate the contributing area of a well. Examples of the use of numerical models for the delineation of contributing areas for wells pumping from stratified drift deposits of New England include those by SEA Consultants, Inc. (1985), Morrissey (1989), Mazzaferro (1989), Edson (1989), and Griswold and Donohue (1989).

Several particle-tracking algorithms have been developed for use with numerical ground-water-flow and transport models, including those of Konikow and Bredehoeft (1978), Ramm and Chazan (1980), Prickett and others (1981), Garabedian and Konikow (1983), Richie and Hoover (1985), Mandle and Kontis (1986), Shafer (1987), and Pollock (1988, 1989). A general particle-tracking program has also been developed for use with WHPA (Well Head Protection Area), a semianalytical ground-water-flow model used in the U.S. Environmental Protection Agency (1990) wellhead protection program.

Reports have been published on the use of particle tracking for delineation of the recharge area to aquifers of Long Island (Buxton and others, 1991) and on the use of particle tracking for determination of flow paths and traveltimes from hypothetical spill sites within the capture area of a well field in Ohio (Bair and others, 1990). A recent comparison between contributing areas determined by use of analytical-modeling techniques and two- and three-dimensional numerical-modeling and particle-tracking techniques, completed as part of this investigation, indicated that contributing areas determined by use of the two techniques were similar for wells pumping from a thin, single-layer, uniform aquifer with near-ideal boundary conditions (the "simple flow system"), and that the use of numerical models for the delineation of contributing areas for wells in such an aquifer may not be warranted (Barlow, 1989a). Numerical modeling and particle tracking provided a better quantitative tool, however, than did the analytical models for conditions normally found in stratified-drift aquifers, such as thick, heterogeneous aquifers with complicated boundary conditions in which several wells are pumped simultaneously. Under these conditions, analytical models were not capable of providing sufficient detail to predict accurately the land area that contributes water to a well. Finally, Springer and Bair (1991) compared an analytical flow model, a semianalytical flow model, and a three-dimensional numerical flow model for the delineation of capture zones for two municipal well fields in a stratified-drift aquifer in a buried valley. They found that the three-dimensional numerical model most accurately predicted hydraulic heads and delineated pathlines for the capture zones of the wells.

\section{Approach}

The delineation of the contributing area of a supply well by means of particle tracking consists of four steps: (1) collection and analysis of well-design characteristics and hydrogeologic data on the aquifer from which the 


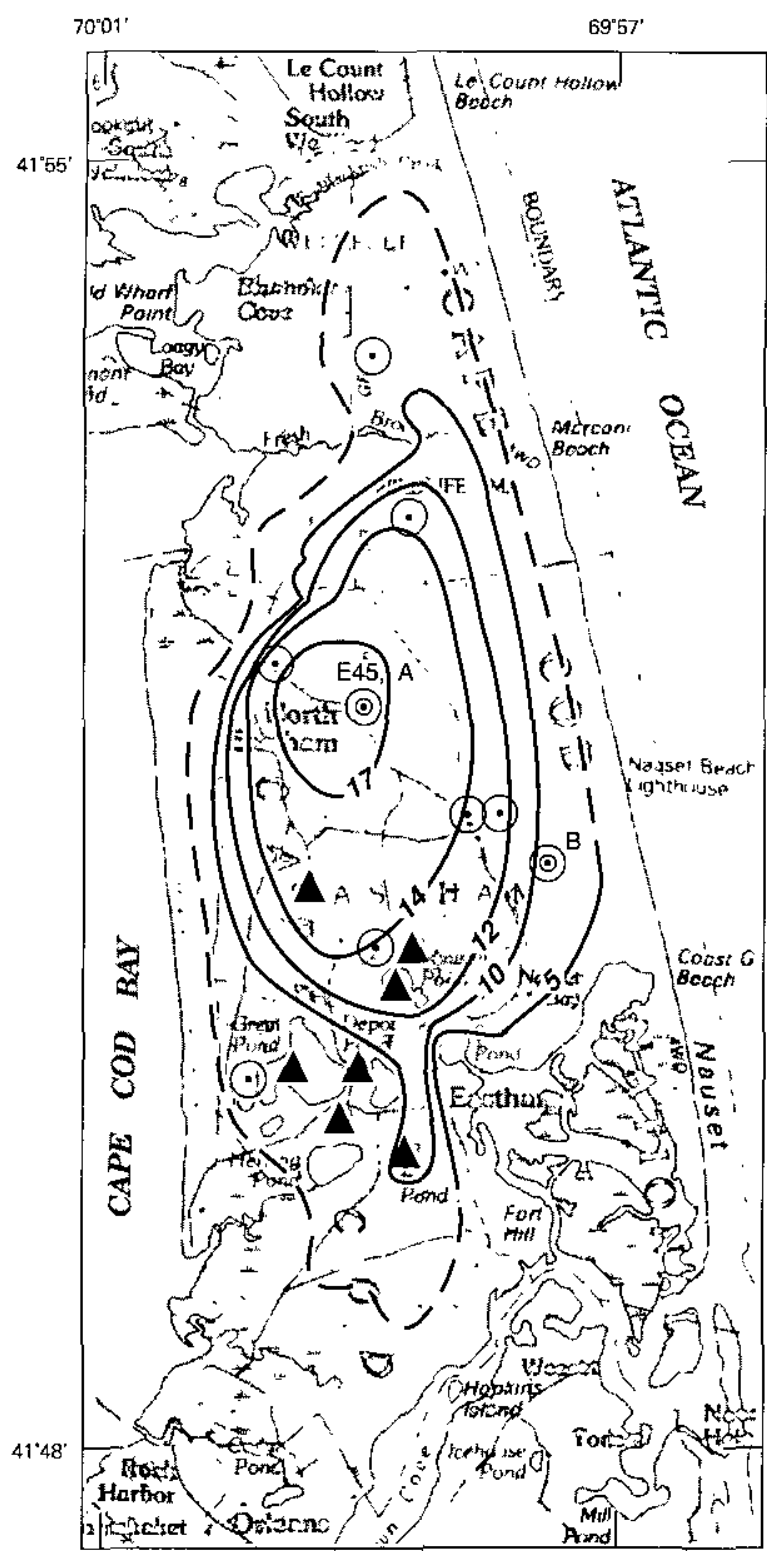

Base from U.S. Geological Survey planimetric maps.

Chatham, 1:100,000, 1986 and

New Bedford, 1:100,000, 1986

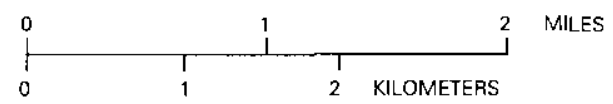

EXPLANATION

-5- - WATER-TABLE CONTOUR--Shows altitude of water table. Dashed where inferred. Contour interval, in feet, is variable. Datum is sea level.

- OBSERVATION WELl at WHICH WATER LEVEL WAS MEASURED

A POND AT WHICH WATER LEVEL WAS MEASURED

(O) SITE OF HYPOTHETICAL PUBLIC-SUPPLY WELL

E45 SITE OF DEEP TEST HOLE

Figure 2. Water-table configuration in the simple flow system, May 1988. 


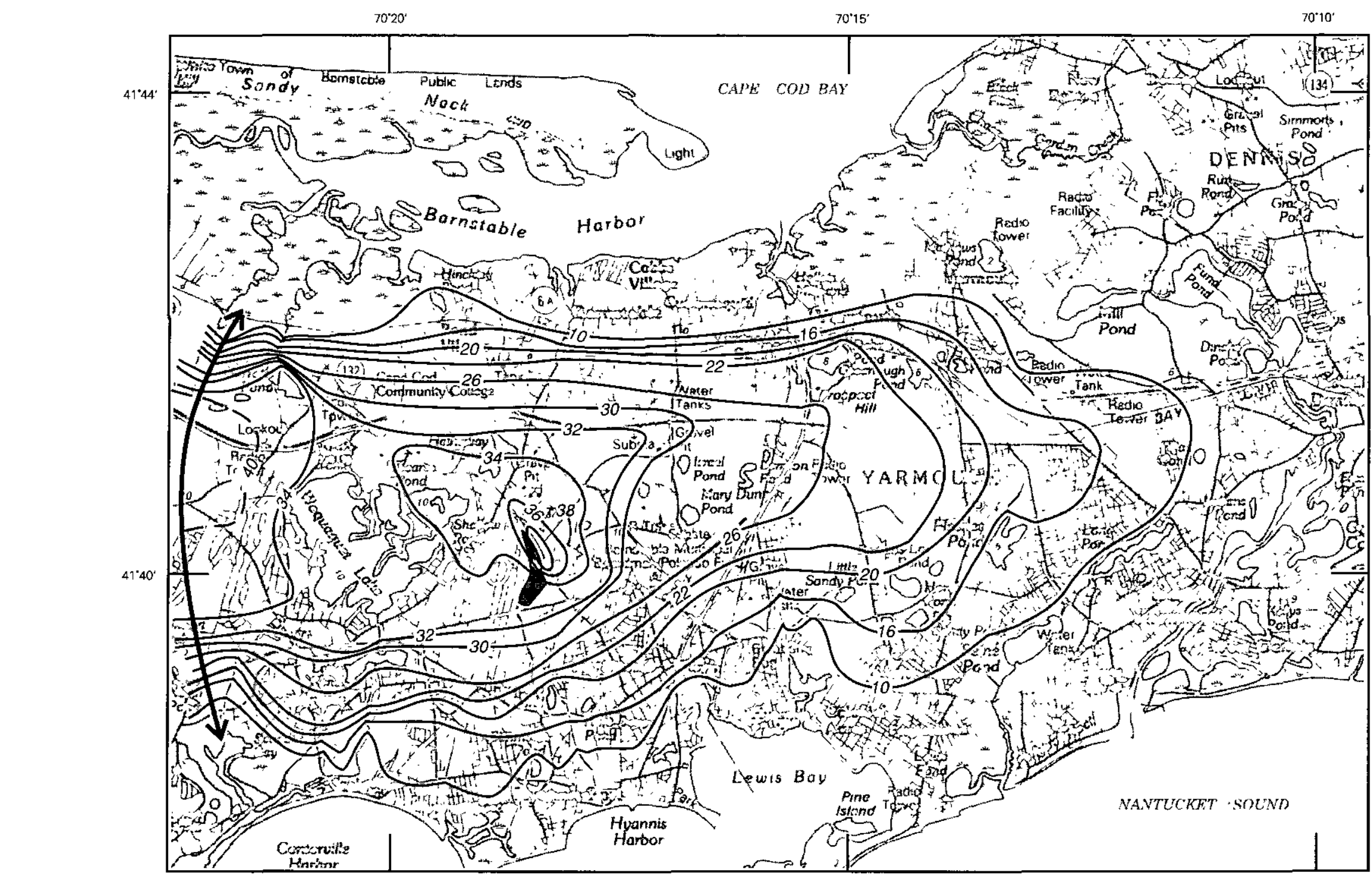

Base from U.S. Geological Survey planimetric maps
New Bedford. Mass., 1984. Scale 1:100,000

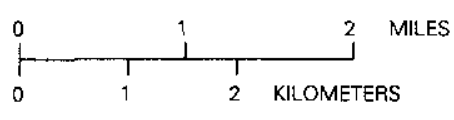

EXPLANATION

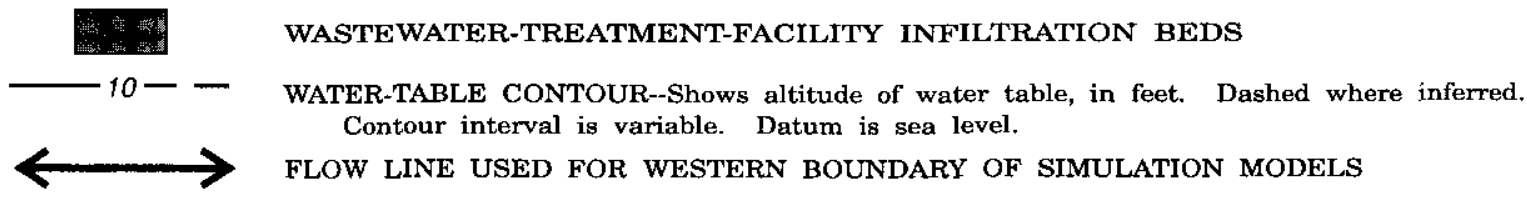

Figure 3. Water-table configuration in the complex flow system, October 14, 1987. 
well pumps; (2) development of a conceptual model of the ground-water-flow system; (3) development and calibration of a numerical ground-water-flow model of the aquifer; and (4) delineation of the contributing area of a well by use of a particle-tracking simulation. The structure of the investigation, as well as the structure of this report, follows this four-step process.

The study relied almost completely on hydrogeologic data collected as part of previous investigations; however, to improve definition of selected areas of the two flow systems, several test holes were drilled for collection of information on lithology and heads. Hydrogeologic data used included (1) lithologic logs of more than 400 boreholes on file in the USGS Ground-Water Site Inventory System; (2) published seismic-refraction surveys; (3) water-table maps and vertical head gradients; (4) estimates of hydraulic conductivity, porosity, and recharge made during this and previous investigations; and (5) general concepts of the ground-waterflow system of Cape Cod presented in Strahler (1972 and 1988), Ryan (1980), and LeBlanc and others (1986). Well-design characteristics were obtained from water companies in Barnstable and Yarmouth.

Conceptual models of ground-water flow were developed for each flow system by synthesis of available well-design characteristics and hydrogeologic data. The conceptual models identify those components of the flow systems that most affect the flow of water and delineation of contributing areas of public-supply wells within them. The conceptual models simplify the real flow systems so that they can be represented by conceptually simpler ground-water-flow models.

Steady-state, two- and three-dimensional models of ground-water flow were developed for each flow system by use of the modular, finite-difference code developed by McDonald and Harbaugh (1988). Three-dimensional models were developed first for each flow system; the three-dimensional models were then simplified vertically to develop two-dimensional models. The model of McDonald and Harbaugh (1988) was chosen for the study because it (1) simulates both two- and threedimensional ground-water flow, (2) contains several options for the specification of boundary conditions, (3) is well documented and widely applied to ground-water investigations, and (4) can be used with a particle-tracking computer program, MODPATH (Pollock, 1988, 1989), that permits delineation of contributing areas. In addition to its use with the McDonald and Harbaugh
(1988) flow model, MODPATH was chosen because it is capable of tracking particle pathlines in two- and three-dimensional flow systems. MODPATH is especially useful because it does not require the specification of discrete solution time steps, thereby avoiding numerical errors and time-step constraints associated with explicit-computation schemes used in some other algorithms (Pollock, 1988, p. 744). Only the advective component of particle transport is simulated by MODPATH; hydrodynamic dispersion and chemical reactions, though important ground-water-transport processes, are not simulated.

\section{Acknowledgments}

The author thanks employees of the water departments in Barnstable and Yarmouth for providing information on ground-water exploration, well discharge, and water quality. The author also thanks the towns of Eastham and Barnstable and the Cape Cod National Seashore for permission to drill test holes for ground water and geologic exploration on town and National Seashore property.

\section{HYDROGEOLOGIC FRAMEWORK}

The Cape Cod peninsula is underlain by sediments deposited during the last glaciation in New England. These unconsolidated sediments constitute the only aquifers and are the primary source of water for Cape Cod residents. Nearly all public-supply wells obtain water from the highly permeable sand and gravel stratified drift. Less permeable glacial moraines consisting of sandy till bound the northern and western edges of the peninsula (fig. 1). The moraines are poorly sorted mixtures of sand, gravel, silt, clay, and boulders, and, because of their low hydraulic conductivity, areas where they are present generally are not developed for public water supply. Lacustrine sediments, consisting of very fine to fine sand, silt, and clay, underlie stratified drift in many areas on the Cape but are not sources of water to Cape residents. Crystalline bedrock underlies the glacial sediments. The bedrock beneath the simple flow system is a fine-grained granite and metagabbro (B.D. Stone, U.S. Geological Survey, written commun., 1987); the type of bedrock underlying the complex flow system has not been determined. 
The simple flow system consists of an upper coarsegrained unit of sand and gravel stratified drift underlain by a fine-grained unit consisting of very fine to fine sand, silt and clay, which may be of lacustrine origin. The upper unit extends from land surface to approximately $100 \mathrm{ft}$ below sea level. Thin, discontinuous lenses of silt and clay are found in this unit and are especially prevalent near Town Cove (fig. 2). The lower unit is more than $300 \mathrm{ft}$ thick at test hole Eastham 45, shown as site E45 on figure 2 (B.D. Stone, written commun., 1987). This fine-grained unit has been identified in several test holes drilled in the northern, western, southern, and central parts of the simple flow system; however, its eastern extent has not been defined. Cored samples from test hole Eastham 45 indicate large percentages of siltand clay-sized fractions for sediments from this unit (table 1).

The complex flow system is bounded to the north (along Cape Cod Bay and Barnstable Harbor) by dune, marsh, and swamp deposits and by the Cape Cod Bay lake deposits, which consist of mostly gravelly sand with fine to very fine sand, silt, and clay (Oldale and Barlow, 1986). These coastal deposits, which extend a maximum of about $1.5 \mathrm{mi}$ inland of Bamstable Harbor, are bounded at land surface to the south by stratified drift in Yarmouth and by moraine in the town of Barnstable. South of the moraine in Bamstable, the flow system is composed almost completely of stratified drift that is underlain in some areas by fine-grained silt and clay. A few scattered ice-contact deposits also are present along Nantucket Sound that consist mostly of sand and gravel (Oldale and Barlow, 1986).

Two primary units have been identified in the stratified drift of Yarmouth: a coarse-grained sand and gravel unit extending from land surface to approximately $110 \mathrm{ft}$ below sea level and a fine-grained unit consisting of fine sand and silt extending from 110 to approximately $150 \mathrm{ft}$ below sea level. These units are locally heterogeneous and include discontinuous lenses of silt and clay. These two units are underlain by a thick deposit of silt and clay, which extends to bedrock and is inferred by Oldale (1974a) to have been deposited in a proglacial lake. Bedrock altitudes in Yarmouth are from 200 to $300 \mathrm{ft}$ below sea level (Oldale, 1974a).

Three primary units within the stratified drift are south of the moraine in Barnstable. These units are (1) an upper coarse-grained unit consisting of sand and gravel, extending from land surface to a depth 0 to $50 \mathrm{ft}$ below sea level, and locally interbedded with finegrained silt and clay, (2) a variably thick, discontinuous lens of silt and clay, which may be of lacustrine origin, extending from the upper coarse-grained unit to a depth of about $120 \mathrm{ft}$ below sea level (and referred to in the remainder of the report as the "fine-grained unit in eastem Barnstable"), and (3) a lower coarse-grained unit consisting of fine to coarse sand, whose total thickness is unknown. The contact between the base of the upper unit and top of the middle unit increases in depth below land surface from north to south. The lateral extent of the middle, fine-grained unit is poorly defincd; however, the unit was identified at many locations in the central part of the complex flow system from just east of Wequaquet Lake to just east of the BarnstableYarmouth town line. Oldale (1974b) noted that these three units may be underlain by a silt and clay lacustrine deposit equivalent to that underlying the outwash of Yarmouth; however, no boreholes have been drilled deep enough to confirm this hypothesis. The contact between glacial deposits and underlying bedrock is estimated from seismic-refraction surveys to be 200 to $500 \mathrm{ft}$ below sea level (Oldale, 1974b). Total thickness of the three units ranges from approximately 250 to $500 \mathrm{ft}$.

\section{Hydraulic Conductivity and Porosity}

Hydraulic conductivity of the stratified drift of Cape Cod has been determined by analysis of aquifer tests done at several locations. Five aquifer tests within the two flow systems were analyzed by use of the method described by Neuman (1974) to estimate horizontal and vertical hydraulic conductivity of stratified drift within these systems. Neuman's method allows for the determination of transmissivity and the ratio of vertical to horizontal hydraulic conductivity; the method is applicable to the analysis of unconfined aquifers in which the pumped and observation wells may fully or partially penetrate the aquifer. Horizontal hydraulic conductivity is determined by dividing the estimate of transmissivity by the saturated thickness of the aquifer near the pumped well. The method is based on the assumption that water is withdrawn from an unconfined, homogeneous, and anisotropic aquifer that is of infinite lateral extent and bounded at depth by an impermeable, horizontal barrier. Neuman's method was used because (1) the tests were done in unconfined aquifers, (2) drawdowns near the pumped wells appeared to be unaffected 
Table 1. Particle-size distributions of cored samples from the simple and complex flow systems and hydraulic conductivity of cored samples from the simple flow system on Cape Cod. Massachusetts

[Sand is defined as particles less than or equal to 4.00 millimeters and greater than 0.062 millimeters; silt is defined as particles less than or equal to 0.062 millimeters and greater than 0.004 millimeters; clay is defined as particles less than or equal to 0.004 millimeters; --, not determined]

\begin{tabular}{|c|c|c|c|c|c|c|c|c|}
\hline \multirow[t]{2}{*}{$\begin{array}{c}\text { Well } \\
\text { identifier }\end{array}$} & \multirow[t]{2}{*}{ Latitude } & \multirow[t]{2}{*}{ Longitude } & \multirow{2}{*}{$\begin{array}{l}\text { Depth of sample, } \\
\text { in feet bclow } \\
\text { sea level }\end{array}$} & \multicolumn{3}{|c|}{$\begin{array}{l}\text { Particle-size } \\
\text { distribution, } \\
\text { in percent }\end{array}$} & \multicolumn{2}{|c|}{$\begin{array}{l}\text { Hydraulic conductivity, } \\
\text { in feet per day }\end{array}$} \\
\hline & & & & Sand & Silt & Clay & Horizontal & Vertical \\
\hline \multicolumn{9}{|c|}{ Simple Flow System } \\
\hline Eastham $45^{1}$ & $41^{\circ} 52^{\prime} 00^{\prime \prime}$ & $69^{\circ} 58^{\prime} 52^{\prime \prime}$ & $\begin{array}{l}203-204 \\
253-254 \\
312-313\end{array}$ & $\begin{array}{l}9 \\
1 \\
2\end{array}$ & $\begin{array}{l}52 \\
57 \\
73\end{array}$ & $\begin{array}{l}39 \\
42 \\
25\end{array}$ & $\begin{array}{c}-- \\
1.6 \times 10^{-4} \\
1.1 \times 10^{-3}\end{array}$ & $\begin{array}{l}7.0 \times 10^{-5} \\
1.1 \times 10^{-4} \\
1.0 \times 10^{-3}\end{array}$ \\
\hline \multicolumn{9}{|c|}{ Complex Flow System } \\
\hline $\begin{array}{l}\text { Barnstable } 488 \\
\text { Barnstable } 489 \\
\text { Barnstable } 490\end{array}$ & $\begin{array}{l}41^{\circ} 39^{\prime} 23^{\prime \prime} \\
41^{\circ} 40^{\prime} 03^{\prime \prime} \\
41^{\circ} 40^{\prime} 42^{\prime \prime}\end{array}$ & $\begin{array}{l}70^{\circ} 20^{\prime} 05^{\prime \prime} \\
70^{\circ} 18^{\prime} 17^{\prime \prime} \\
70^{\circ} 16^{\prime} 58^{\prime \prime}\end{array}$ & $\begin{array}{r}129-130 \\
50-52 \\
68-70\end{array}$ & $\begin{array}{r}59 \\
2 \\
9\end{array}$ & $\begin{array}{l}22 \\
76 \\
68\end{array}$ & $\begin{array}{l}19 \\
22 \\
23\end{array}$ & $\begin{array}{l}-- \\
-- \\
--\end{array}$ & $\begin{array}{l}-- \\
-- \\
--\end{array}$ \\
\hline
\end{tabular}

${ }^{1}$ Shown as E45 on figure 2.

by lateral recharge or leaky or impermeable boundaries, (3) previous investigations indicate that the stratifieddrift aquifers of Cape Cod are anisotropic, and (4) the pumped well and observation wells partially penetrate the aquifers.

Results from analyses of the five aquifer tests (table 2) indicate that horizontal hydraulic conductivity generally increases as grain size increases, from about $160 \mathrm{ft} / \mathrm{d}$ for fine sand to $300 \mathrm{ft} / \mathrm{d}$ for coarse to very coarse sand. Results also indicate that the ratio of vertical to horizontal hydraulic conductivity for all sediments except fine sand ranges from 1:1 to 1:10; the ratio for fine sand is $1: 30$. The accuracy of the hydraulic conductivity estimates is limited by the degree to which the assumptions of each analytical method are satisficd by each aquifer test. The greatest source of error in the five tests was uncertainty in the saturated thickness of the aquifer near the pumped well; however, these estimates are consistent with independent estimates of hydraulic conductivity reported for other stratified-drift deposits of New England and Long Island (Allen and others, 1966; McClymonds and Franke, 1972; Lindner and Reilly, 1983; Dickerman, 1984; Olimpio and de Lima, 1984; Prince and Schneider, 1989).

Although the aquifer-test analyses provide estimates of the hydraulic conductivity of sand and gravel, the hydraulic conductivity of fine-grained sediments that are prevalent in the two flow systems is largely unknown. To determine the hydraulic conductivity of these sediments, investigators completed laboratory pcrmeameter tests on cored samples collected at test hole Eastham 45 (H.W. Olsen, U.S. Geological Survey, written commun., 1988). The horizontal and vertical hydraulic conductivity of these samples were five to seven orders of magnitude less than those estimated for sand and gravel (tables 1 and 2). Hydraulic conductivity of the fine-grained unit in eastern Bamstable is not known, but these sediments are generally coarser and less compact than fine-grained sediments within the simple flow system and, therefore, are likely to be more permeable. Three grain-size distributions of sediments from the complex flow system provide representative data on the composition of this fine-grained unit (table 1). The samples range from silty, clayey sand to silt and clay.

Estimates of hydraulic conductivity for coarse- and fine-grained sediments were used to derive generalized values of hydraulic conductivity for sediments of the two flow systems (table 3 ). These generalized values represent approximate averages for each sediment size and were used to estimate hydraulic conductivity for the ground-water-flow models.

Porosity of stratified drift of Cape Cod, estimated from ground-water tracer experiments done in 
Table 2. Hydraulic conductivity of stratified drift at selected well locations on Cape Cod, Massachusetts

[Horizontal hydraulic conductivity values are in feet per day; --, data not available]

\begin{tabular}{|c|c|c|c|c|c|c|}
\hline $\begin{array}{l}\text { Predominant } \\
\text { grain size }\end{array}$ & $\begin{array}{c}\text { Well } \\
\text { identifier }\end{array}$ & Latitude & Longitude & $\begin{array}{l}\text { Hori- } \\
\text { zontal } \\
\text { hydraulic } \\
\text { conduc- } \\
\text { tivity }\end{array}$ & $\begin{array}{l}\text { Ratio of } \\
\text { vertical } \\
\text { to hori- } \\
\text { zontal } \\
\text { hydraulic } \\
\text { conduc- } \\
\text { tivity }\end{array}$ & $\begin{array}{l}\text { Source } \\
\text { of data }\end{array}$ \\
\hline Fine sand & $\begin{array}{l}\text { Barnstable } 406 \\
\text { Yarmouth } 74\end{array}$ & $\begin{array}{l}41^{\circ} 39^{\prime} 13^{\prime \prime} \\
41^{\circ} 40^{\prime} 00^{\prime \prime}\end{array}$ & $\begin{array}{l}70^{\circ} 22^{\prime} 15^{\prime \prime} \\
70^{\circ} 14^{\prime} 52^{\prime \prime}\end{array}$ & $\begin{array}{l}160 \\
160\end{array}$ & $\begin{array}{l}1: 30 \\
1: 30\end{array}$ & $\begin{array}{l}\text { This investigation } \\
\text { This investigation }\end{array}$ \\
\hline $\begin{array}{l}\text { Fine to } \\
\text { medium } \\
\text { sand }\end{array}$ & $\begin{array}{l}\text { Wellfleet } 41 \\
\text { Yarmouth } 176 \\
\text { Falmouth } 214\end{array}$ & $\begin{array}{l}41^{\circ} 54^{\prime} 00^{\prime \prime} \\
41^{\circ} 39^{\prime} 16^{\prime \prime} \\
41^{\circ} 37^{\prime} 03^{\prime \prime}\end{array}$ & $\begin{array}{l}69^{\circ} 58^{\prime} 42^{\prime \prime} \\
70^{\circ} 11^{\prime} 48^{\prime \prime} \\
70^{\circ} 33^{\prime} 00^{\prime \prime}\end{array}$ & $\begin{array}{l}180 \\
200 \\
380\end{array}$ & $\begin{array}{l}1: 3-1: 5 \\
-- \\
1: 2-1: 5\end{array}$ & $\begin{array}{l}\text { This investigation } \\
\text { Guswa and LeBlanc, } 1985 \\
\text { LeBlanc and others, } 1988\end{array}$ \\
\hline $\begin{array}{l}\text { Very fine to } \\
\text { coarse sand }\end{array}$ & Truro 200 & $42^{\circ} 00^{\prime} 51^{\prime \prime}$ & $70^{\circ} 02^{\prime} 48^{\prime \prime}$ & 220 & $1: 1-1: 5$ & Guswa and Londquist, 1976 \\
\hline $\begin{array}{l}\text { Fine to } \\
\text { coarse sand }\end{array}$ & $\begin{array}{l}\text { Yarmouth } 59 \\
\text { Yarmouth } 129\end{array}$ & $\begin{array}{l}41^{\circ} 40^{\prime} 10^{\prime \prime} \\
41^{\circ} 40^{\prime} 22^{\prime \prime}\end{array}$ & $\begin{array}{l}70^{\circ} 13^{\prime} 53^{\prime \prime} \\
70^{\circ} 14^{\prime} 19^{\prime \prime}\end{array}$ & $\begin{array}{l}220 \\
240\end{array}$ & $\begin{array}{l}1: 10 \\
1: 3-1: 5\end{array}$ & $\begin{array}{l}\text { This investigation } \\
\text { This investigation }\end{array}$ \\
\hline $\begin{array}{l}\text { Coarse to very } \\
\text { coarse sand }\end{array}$ & Orleans 37 & $41^{\circ} 45^{\prime} 16^{\prime \prime}$ & $69^{\circ} 59^{\prime} 39^{\prime \prime}$ & 300 & $\begin{array}{l}\text { less than } \\
1: 10\end{array}$ & Guswa and LeBlanc, 1985 \\
\hline
\end{tabular}

Table 3. Hydraulic conductivity for glacial sediments of Cape Cod, Massachusetts, generalized from tables 1 and 2

\begin{tabular}{lcc}
\hline Lithology & $\begin{array}{c}\text { Horizontal } \\
\text { hydraulic } \\
\text { conductivity, } \\
\text { in feet per day }\end{array}$ & $\begin{array}{c}\text { Ratio of } \\
\text { vertical to } \\
\text { horizontal } \\
\text { hydraulic } \\
\text { conductivity }\end{array}$ \\
\hline Silt and (or) clay & 0.001 & $1: 1$ \\
Very fine sand & 100 & $1: 30$ \\
Fine sand & 160 & $1: 30$ \\
Medium sand & 200 & $1: 5$ \\
Coarse sand & 280 & $1: 5$ \\
Gravel & 400 & $1: 5$ \\
\hline
\end{tabular}

Falmouth (fig. 1), ranges from about 0.38 to 0.42 (Garabedian, 1987, p. 163; LeBlanc and others, 1988, p. B-7; Barlow, 1989b, p. 327). Although these tracer tests are the only source of porosity estimates for stratified drift on Cape Cod, they are consistent with those reported for other stratified-drift deposits. Morris and Johnson (1967, D20-D29) reported a mean porosity of 0.43 for unconsolidated fine-grained sand, 0.39 for unconsolidated medium- and coarse-grained sand, and 0.39 for "washed drift" sand (outwash and ice-contact deposits). Perlmutter and Leiber (1970) reported a range of porosity of 0.34 to 0.38 for sand and gravel outwash of Long Island, N.Y. Porosity of the primarily silt and clay sediments from test hole Eastham 45 range from 0.68 to 0.72 (H.W. Olsen, written commun., 1988); these porosities are greater than those reported for coarse-grained sediments because the percentages of silt and clay of these fine-grained sediments are larger than those of the coarse-grained sediments.

\section{Ground-Water-Flow Systems}

The bays, estuaries, and streams of Cape Cod physically divide ground-water flow into six flow systems, or flow cells, which are hydraulically independent under natural conditions (LeBlanc and others, 1986, pl. 2). Water from precipitation and wastewater return flow recharges the aquifer, flows laterally through the sediments, and discharges to the ocean, saltwater bays, inlets, canals, and streams. Ground-water discharge also 
occurs by pumping and by evapotranspiration in areas in which the water table is near land surface. Ground water is generally unconfined within the flow systems: the upper boundary of each system is the water table, which fluctuates in response to variations in recharge and discharge. The flow systems locally may be semiconfined where silt and clay overlic more permeable sand and gravel. The lower boundary of the groundwater-flow systems is either bedrock, poorly permeable sediments such as silt and clay, or the transition zone between freshwater and saltwater. Ground-water flow in each flow system is approximately steady because of a long-term balance between recharge and discharge; therefore, the configuration of the flow systems remains approximately constant from year to year (LeBlanc and others, 1986, pl. 2).

Precipitation is estimated to be about 40.4 and $43.7 \mathrm{in} / \mathrm{yr}$ in the areas of the simple and complex flow systems, respectively, whereas the rate of recharge to the water table from precipitation is estimated to average about 17.4 and $18.9 \mathrm{in} / \mathrm{yr}$ in the simple and complex flow systems, respectively (LeBlanc and others, 1986, pl. 2). Ponds also receive precipitation, some of which recharges the underlying aquifer, however, evaporation from pond surfaces results in lower aquifer recharge rates beneath ponds than beneath land. Farnsworth and others (1982, map 1) estimate that pond evaporation rates are about $28 \mathrm{in} / \mathrm{yr}$ on Cape Cod; therefore, net recharge to aquifers underlying ponds is approximately 12.4 and $15.7 \mathrm{in} / \mathrm{yr}$ in the simple and complex flow systems, respectively. Most ground-water recharge is during late fall, winter, and spring, when evapotranspiration rates are low and precipitation rates are high; little ground-water recharge occurs during late spring, summer, and early fall, when precipitation rates are low and evapotranspiration rates are high.

In addition to precipitation recharge, wastewater return flow through septic systems and from wastewater-treatment facilities can be a significant source of recharge in highly developed areas of Cape Cod. Recharge from septic systems depends on the density of residential housing and commercial facilities within specific areas; recharge rates from septic systems were estimated to be 3 to $6 \mathrm{in} / \mathrm{yr}$ within developed areas of the complex flow systems (discussed in greater detail in "Numerical Models of Ground-Water Flow Used in Particle-Tracking Analysis").
Most ponds in the flow systems are connected hydraulically to the surrounding aquifer. Compared to other parts of the aquifer, water-level altitudes across ponds are nearly flat, because there is little resistance to ground-water flow within the ponds. Water-table contours bend upgradient on the upgradient ends of ponds and downgradient on the downgradient ends. This shape of the water table near ponds focuses ground-water inflow to the upgradient ends of ponds and pond-water outflow into the surrounding aquifer on the downgradient ends of ponds; consequently, ponds are areas of ground-water throughflow.

\section{Simple Flow System}

A map of water-table altitudes was made for the simple flow system from water levels measured in six wells and seven ponds during May 1988 (fig. 2). Three additional wells that were not measured in May 1988 but whose average water levels are reported by LeBlanc and others (1986, pl. 4) were also used in the development of the water-table map. Water levels in threc of the wells measured in May 1988 with periods of record of 8 to 25 years were within 5 percent of long-term average conditions at this time. Consequently, the water-table map is considered representative of near-average conditions for the flow system.

The general direction of ground-water flow in the simple flow system is radially outward from a watertable mound in central Eastham to saltwater discharge boundaries at the Atlantic Ocean, Town Cove, Rock Harbor, and Cape Cod Bay (fig. 2). In addition to these saltwater boundaries, the flow system is also bounded by ground-water divides that separate the simple flow system from adjacent flow systems to the north and south. The divides function as no-flow boundarics, across which ground water does not flow. Water levels measured in multilevel well clusters in the stratified drift indicate that ground water generally moves downward in the area of the water-table mound and upward near areas of discharge. Vertical gradients at the watertable mound are approximately $0.001 \mathrm{ft} / \mathrm{ft}$ within the coarse-grained unit of sand and gravel. Vertical gradients between the coarse-grained stratified drift and underlying fine-grained unit and within the fine-grained unit are unknown. Because of the low hydraulic conductivity of the lower unit, very little water is assumed to flow through it. 
Saltwater underlies the freshwater flow system. Freshwater and saltwater are separated by a transition zone in which the waters mix. Freshwater and saltwater are in hydrodynamic balance along the transition zone and seaward-flowing freshwater prevents the landward intrusion of saline water, which is denser than freshwater. The depth to the top of the transition zone increases as the altitude of the water table increases. The position of the transition zone has been determined at two sites in the flow system. Near the coast, where the water table is close to sea level, the top of the transition zone lies about $50 \mathrm{ft}$ below sea level and the zone is less than $20 \mathrm{ft}$ thick (LeBlanc and others, 1986, pl. 4). At test hole Eastham 45 (fig. 2), near the top of the water-table mound, the water table is about $18 \mathrm{ft}$ above sea level and the top of the transition zone is nearly $350 \mathrm{ft}$ below sea level. This is approximately $275 \mathrm{ft}$ below the contact between the upper coarse-grained and lower finegrained units at this site. The transition zone here is about $70 \mathrm{ft}$ thick. Because of the widespread distribution of the fine-grained unit in the flow system, the interface is assumed to lie within the fine-grained unit over much of the flow system.

No public-water systems operate within the simple flow system. Residences and commercial facilities pump from privately owned, onsite, small-capacity wells. Most ground water pumped from these wells is returned to the underlying aquifer by onsite septic systems and, therefore, the net ground-water discharge is assumed to be nearly zero.

\section{Complex Flow System}

A map of water-table altitudes was made for the complex flow system from water levels measured in 67 observation wells and 5 ponds on October 14, 1987 (fig. 3). Water levels in nine of the observation wells distributed throughout the flow system with periods of record of 15 to 32 years indicate that water levels at that time were within 7 percent of long-term average conditions. Consequently, the water-table map is considered representative of near-average conditions.

Water-table contours indicate that Wequaquet Lake, a large lake near the westem border of the study area, receives discharge from the aquifer from the west and east and discharges water to the aquifer along its northern and southem boundaries. West of the lake, ground water flows northward to Barnstable Harbor and southward to Nantucket Sound (fig. 3); east of the lake, ground water flows from a water-table mound near the lake north to Barnstable Harbor, south to Nantucket Sound, and east and southeast to the Bass River. Ground water is mounded east of the lake by the fine-grained silt and clay unit in eastern Barnstable.

The flow system is bounded on three sides by saltwater bodies that are areas of ground-water discharge. The position of the transition zone between freshwater and saltwater in the aquifer has been determined at several sites (LeBlanc and others, 1986, pl. 2). Semiconfining conditions caused by very fine sand, silt, and clay-sized lacustrine sediments along Barnstable Harbor and Cape Cod Bay force the transition zone offshore. Along Nantucket Sound, however, ground water discharges at the coastline, and the transition zone falls sharply landward from the coast as the altitude of the water table increases. A ground-water-flow model of this area indicates that the interface between freshwater and saltwater is intersected by bedrock close to Nantucket Sound (Guswa and LeBlanc, 1985).

Most discharge from the aquifer is to the surrounding saltwater bodies; however, ground water also discharges to several small streams and to public-supply wells. Residents and commercial facilities in the complex flow system are served by five water companies: Barnstable Water Company, Barnstable Fire District, Centerville-Osterville Fire District, Cotuit Fire District, and Yarmouth Water Company. In 1987, these companies pumped an average of $10.3 \mathrm{Mgal} / \mathrm{d}$. Most of this water is retumed to the aquifer through infiltration from septic systems; however, parts of Bamstable are sewered. Sewered water is treated at a wastewater-treatment facility and returned to the aquifer through infiltration beds. In 1987, the facility discharged treated water to the infiltration beds at an average rate of $1.3 \mathrm{Mgal} / \mathrm{d}$. In addition to the water companies, three privately owned wells supply water onsite to two golf courses in Bamstable. Each year these wells withdraw a small volume of water compared to public-supply wells. Most water pumped from these three wells is assumed to be returned to the aquifer onsite. An additional well operated by a local quarry was pumped at an average daily rate (in 1987) of $0.2 \mathrm{Mgal}$ for use at the plant. 


\section{NUMERICAL MODELS OF GROUND-WATER FLOW USED IN PARTICLE-TRACKING ANALYSIS}

Steady-state, two- and three-dimensional groundwater-flow models were developed for each flow system on the basis of hydrogeologic data and well-design characteristics described in the preceding section. Steady-state models imply that heads and flow rates do not change with time. Although seasonal variations in the rates of ground-water recharge and pumping cause ground-water movement into and out of storage, ground-water flow in each of the two flow systems is approximately steady because of the long-term balance between recharge and discharge. On average, ground water removed from storage during periods of low recharge and high ground-water pumping is replaced by recharge during periods of lower pumping, and the net movement of water to storage is zero. Limitations to the use of steady-state models for delineation of contributing areas are discussed in the "Data Requirements for and Limitations of Particle Tracking for Delineation of Contributing Areas" section of this report.

Several characteristics of the models are common to both flow systems. First, the upper boundary of each flow model is the water table, the altitude of which is calculated for each cell of the top layer of each model. Second, ponds were modeled in the top layer of each three-dimensional model by assigning a very high horizontal hydraulic conductivity $(50,000 \mathrm{ft} / \mathrm{d})$ to model cells underlying ponds. This was done so that the dampening effect of ponds on water-table altitudes could be simulated. Ponds were not modeled in the two-dimensional simulations because most ponds in the study areas are shallow; the mean bottom altitude of 48 ponds in the study areas is $2.7 \mathrm{ft}$ above sea level (McCann, 1969). Third, it was assumed that the crystalline bedrock underlying the two flow systems is impermeable. This assumption was based on the very low values of hydraulic conductivity reported for crystalline rocks similar to those of Cape Cod (Davis and DeWeist, 1966, p. 164, 320; Freeze and Cherry, 1979, p. 29; Marsily, 1986, p. 78). Finally, movement of the interface between freshwater and saltwater in each aquifer was not simulated. It was assumed that pumping scenarios studied during the investigation would not significantly affect the existing hydrodynamic balance along the transition zone in each flow system. Furthermore, the location of the interface was assumed to coincide with lateral boundaries of each model, and seabed discharge boundaries are assumed to be underlain by freshwater. This assumption was made because the interface is generally confined to areas near the coasts throughout most of Cape Cod; the depth to the interface increases sharply landward of the coasts in response to ground-water heads that increase parabolically away from the coastal discharge areas. Although this is not entirely true within the simple flow system, because of the location of the interface within the fine-grained unit and very low hydraulic conductivity of this unit, the interface is assumed to have little effect on the flow of water in the upper coarse-grained unit in which the hypothetical wells were located.

\section{Simple Flow System}

Flow models for the simple flow system extend from Town Cove and Rock Harbor in southem Eastham to South Wellfeet and from Cape Cod Bay eastward to the Atlantic Ocean (fig. 4).

\section{Conceptual Model of Ground-Water Flow}

The following statements and assumptions describe the conceptual model of the simple flow system.

1. The flow system consists of two layers: a thin, highly permeable sand and gravel unconfined aquifer underlain by a much less permeable confining unit composed of very fine to fine sand, silt, and clay.

2. The flow system is bounded laterally by saltwater discharge areas at the Atlantic Ocean, Town Cove, Rock Harbor, and Cape Cod Bay. The flow system is also bounded along the north and a small part of the south by ground-water divides that separate the simple flow system from adjacent flow systems. It is assumed that these divides are unaffected by any groundwater withdrawals from the system. The flow system is bounded at depth by impermeable, crystalline bedrock.

3. Ground-water recharge to the water table is uniform over the flow system except at ponds, where rates of areal recharge are smaller than those in other areas because of evaporation from pond surfaces. 


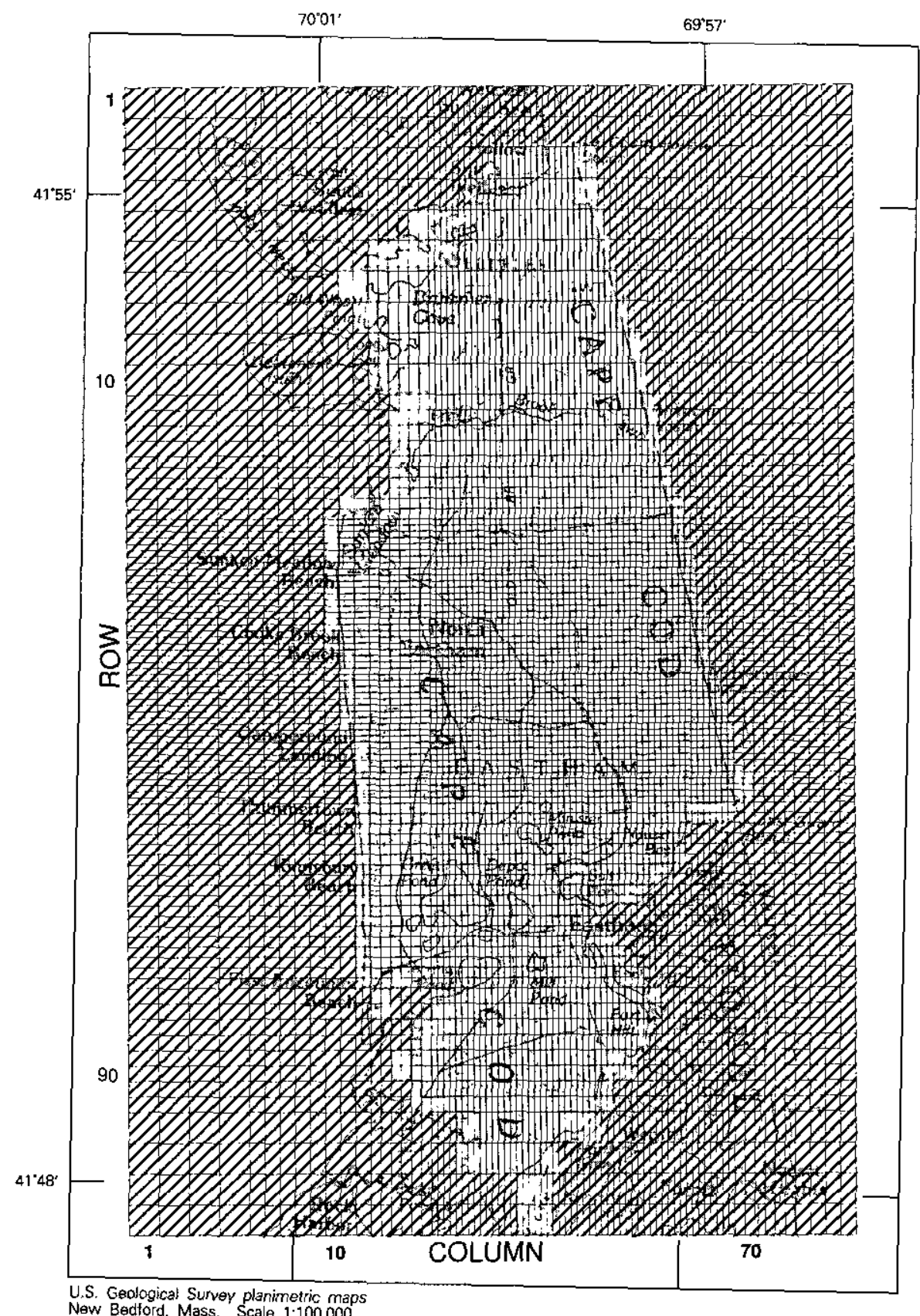

New Bedford. Mass. Survey planimetric maps

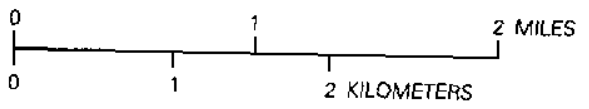

EXPLANATION

$\square$ ACTIVE CELL
DID INACTIVE CELL--Outside of modeled area.
$\square$ SPECIFIED-HEAD CELL--Constant head during simulations.

Figure 4. Model grid and lateral boundary conditions for the two-dimensional flow model and the top layer of the three-dimensional flow model of the simple flow system. 
4. Ground-water flow is virtually horizontal in the aquifer except near divides and discharge boundaries where vertical flow dominates. Vertical leakage occurs between the aquifer and underlying confining unit; however, little water flows through the confining unit because of its low permeability.

\section{Three-Dimensional Model}

Hydrogeologic data, well-design characteristics, and the conceptual model of ground-water flow were used to develop the three-dimensional model of the simple flow system. The model was calibrated to heads measured in the flow system during average water-level conditions.

\section{Grid}

The three-dimensional flow model consists of five layers (table 4) that were chosen on the basis of available information on the lithology of the flow system and were designed for adequate representation of the contact between the upper coarse-grained and lower finegrained units. More than one model layer was used to simulate the coarse-grained unit in order to vary the location of the well screens of the hypothetical wells. The model grid consists of 96 rows and 78 columns and was aligned to conform as closely as possible to natural boundaries of the aquifer (fig. 4). Grid cells are smallest (264 ft by $264 \mathrm{ft}$ ) in the area of proposed well sites, to simulate as accurately as possible the movement of water particles near those wells.

\section{Boundary Condlitions}

Specified-head boundaries were used in the top layer of the model to simulate saltwater discharge areas that surround much of the flow system (fig. 4). Active model cells underlie the specified-head boundaries in layers 2 through 5. Equivalent freshwater heads were computed and used at the specified-head boundaries to account for the higher density saltwater that overlies freshwater at the seabed discharge boundaries. Because freshwater and saltwater heads are equal at the discharge boundary, an equivalent freshwater head can be determined by equation 1:

$$
Z(f)=\frac{\rho(s)-\rho(f)}{\rho(f)} Z(s)
$$

where

$$
\begin{aligned}
& Z(f) \quad \text { is equivalent freshwater head, in } \\
& \text { feet; } \\
& Z(s) \text { is distance from sea level to } \\
& \text { seabed, in fcet (from } \\
& \text { bathymetric maps of the area); } \\
& \rho(s) \text { is density of saltwater, assumed to } \\
& \text { be } 1.025 \mathrm{gm} / \mathrm{cm}^{3} \text {; and } \\
& \rho(f) \text { is density of freshwater, assumed } \\
& \text { to be } 1.000 \mathrm{gm} / \mathrm{cm}^{3} \text {. }
\end{aligned}
$$

A stream-surface boundary (or no-flow boundary) was specified along parts of the northern and southern boundaries of the flow system to coincide with the natural ground-water-flow divides that separate the flow system from adjacent flow systems. A stream-surface boundary also was used to simulate the contact between glacial sediments and underlying bedrock.

A recharge rate of $17.4 \mathrm{in} / \mathrm{yr}$ was specified to the top layer of the model on the basis of estimates made by LeBlanc and others (1986, pl. 2). Pond cells were assigned a recharge rate of only $12.4 \mathrm{in} / \mathrm{yr}$ because of evaporation losses from pond surfaces. Return flow from domestic and commercial septic systems was assumed to be equal to the amount of water withdrawn by wells at each site; therefore, net ground-water withdrawal for public supply was assumed to be zero.

\section{Hydraulic Properties}

Horizontal hydraulic conductivity and vertical conductance were determined for the top four layers of the model at 31 sites by comparison of lithologic logs of test holes at these sites to generalized hydraulic conductivities for glacial sediments (table 3). Each lithologic log was divided into layers corresponding to those of the three-dimensional model. An equivalent horizontal hydraulic conductivity, $K_{h}$, was then computed for each layer of the log, according to the method described by Freeze and Cherry $(1979$, p. 34$)$ :

$$
K_{h}=\frac{\sum_{i=1}^{n} K_{i} b_{i}}{\sum_{i=1}^{n} b_{i}},
$$


Table 4. Vertical layering, horizontal hydraulic conductivity, and vertical conductance of the calibrated three- and two-dimensional flow models of the simple flow system

[The bottom altitude and horizontal hydraulic conductivity of layer 5 of the three-dimensional model were not specified because transmissivity was used for the layer; --, vertical conductance was not specified for either layer 5 of the three-dimensional model or for the single layer of the two-dimensional model]

\begin{tabular}{cccc}
$\begin{array}{c}\text { Model } \\
\text { layer }\end{array}$ & $\begin{array}{c}\text { Altitude } \\
\text { of layer } \\
\text { bottom, in } \\
\text { feet below } \\
\text { sea level }\end{array}$ & $\begin{array}{c}\text { Horizontal } \\
\text { hydraulic } \\
\text { conductivity, in } \\
\text { feet per day }\end{array}$ & $\begin{array}{c}\text { Vertical } \\
\text { conductance, } \\
\text { in day }^{-1}\end{array}$ \\
\hline
\end{tabular}

Three-dimensional model

$\begin{array}{rrrr}1 & 10 & 100-150^{1} & 0.005-1.0 \\ 2 & 35 & 50-100 & 0.0001-1.0 \\ 3 & 60 & 0.001-100 & 0.00001 \\ 4 & 90 & 0.001-100 & 0.00001\end{array}$

Two-dimensional model

$\begin{array}{llll}1 & 90 & 25-75\end{array}$

${ }^{1}$ Grid cells underlying ponds were assigned a horizontal hydraulic conductivity of 50,000 feet per day.

where

\begin{tabular}{|c|c|c|}
\hline$X_{h}$ & is & $\begin{array}{l}\text { equivalent horizontal hydraulic } \\
\text { conductivity for the layer, in } \\
\text { feet per day; }\end{array}$ \\
\hline$K_{i}$ & is & $\begin{array}{l}\text { horizontal hydraulic } \\
\text { conductivity of the } i \text { th } \\
\text { hydrogeologic unit of the } \\
\text { layer, in feet per } \\
\text { day (estimated from table 3); }\end{array}$ \\
\hline$b_{i}$ & is & $\begin{array}{l}\text { thickness of the } i \text { th } \\
\text { hydrogeologic unit in the } \\
\text { layer, in feet; and }\end{array}$ \\
\hline$n$ & is & $\begin{array}{l}\text { the number of hydrogeologic } \\
\text { units within the layer; the top } \\
\text { of the uppermost layer } \\
\text { coincides with the position of } \\
\text { the water table. }\end{array}$ \\
\hline
\end{tabular}

Vertical conductance is specified between vertically adjacent nodes of the McDonald and Harbaugh (1988, p. 5-11) model. Vertical conductance was determined for each $\log$ from the relation:

$$
V \operatorname{cont}(k+1 / 2)=\frac{1}{\sum_{i=1}^{n} \frac{b_{i}}{K_{v_{i}}}}
$$

where

$$
\begin{gathered}
V \text { cont } t_{(k+1 / 2)} \begin{array}{c}
\text { is vertical conductance between } \\
\text { layers } k \text { and } k+1 \text {, in day }
\end{array} \\
K_{v_{i}} \text { is } \begin{array}{c}
\text { vertical hydraulic conductivity of } \\
\text { the } i \text { th hydrogeologic unit } \\
\text { between layers } k \text { and } \\
k+1, \text { in feet per day; }
\end{array} \\
b_{i} \text { is } \begin{array}{c}
\text { thickness of the } i \text { th hydrogeologic } \\
\text { unit between layers } k \text { and } k+1, \\
\text { in feet; and }
\end{array} \\
n \quad \begin{array}{c}
\text { is the number of hydrogeologic units } \\
\text { between layer } k \text { and } k+1 .
\end{array}
\end{gathered}
$$

Maps of the spatial variation of horizontal hydraulic conductivity and vertical conductance were made for layers 1 through 4 by use of the values of horizontal hydraulic conductivity and vertical conductance computed for each layer of the 31 logs. These maps served as initial estimates of horizontal hydraulic conductivity and vertical conductance of the three-dimensional model. Transmissivity of layer $5\left(0.378 \mathrm{ft}^{2} / \mathrm{d}\right)$ was determined by multiplying the generalized horizontal hydraulic conductivity of silt and clay determined through laboratory permeameter tests $(0.001 \mathrm{ft} / \mathrm{d}$, table 3 ) by the total thickness of the deposit at test hole Eastham $45(378 \mathrm{ft})$.

\section{Calibration and Sensiflvily}

The model was calibrated by comparison of calculated heads to heads measured at 19 locations in the aquifer in May 1988 and three additional locations reported by LeBlanc and others (1986, pl. 4). Heads at this time were used for model calibration because they are considered representative of average (steady-state) conditions. Initial estimates of recharge, horizontal hydraulic conductivity, and vertical conductance were adjusted during model calibration. Horizontal hydraulic conductivity and vertical conductance were decreased by a maximum of 30 percent during model calibration, and recharge was increased over the initial estimate by 5 percent. Differences between initial estimates of horizontal hydraulic conductivity and calibrated model values were greatest for coarse and very coarse sand deposits. The decrease in both horizontal hydraulic 
conductivity and vertical conductance with increasing depth of each model layer (table 4) is consistent with the lithology of the flow system.

A map of calculated water-table altitudes for the top layer of the model is shown in figure $5 \mathrm{~A}$. Generally, agreement between observed and calculated heads is close at each of the observation points (table 5). The mean error of the absolute value of observed minus calculated heads is $0.8 \mathrm{ft}$, which corresponds to approximately 4 percent of the total relief of the water table in the simple flow system. The errors are distributed around a mean value of $0.14 \mathrm{ft}$, indicating a small positive bias in calculated heads but no significant systematic error in calibrated model parameters. Total steadystate recharge to the calibrated model is $22.1 \mathrm{ft}^{3} / \mathrm{s}$, or $14.3 \mathrm{Mgal} / \mathrm{d}$, nearly 50 percent of which is discharged from layer 1 to specified-head boundaries at the coast without flowing to layers 2 through 5 . Layer 5 receives much less than 1 percent of available recharge to the model.

A sensitivity analysis was done to determine the response of calculated heads to changes in model parameters. The analysis was done because model parameters (horizontal hydraulic conductivity, transmissivity, vertical conductance, and recharge) are imprecise estimates of the true values. The uncertainty associated with each parameter can have a significant effect on calculated heads and flows, and, therefore, on the contributing areas delineated for supply wells. The sensitivity analysis can identify those parameters to which model results are most sensitive and can guide future data collection toward improved definition of those parameters.

During the sensitivity analysis, each model parameter was uniformly increased or decreased and the model was then rerun. The mean error of the absolute value of the difference between observed and calculated heads was then determined. Calculated heads were found to be most sensitive to recharge and to the horizontal hydraulic conductivity of the top layer of the model (fig. $6 \mathrm{~A}$ ). Heads were less sensitive to horizontal hydraulic conductivity of layers 2 through 4 ; heads were nearly insensitive to increases or decreases in the transmissivity of layer 5 (fig. $6 B$ ). In general, heads were less sensitive to variations in vertical conductance than to variations in horizontal hydraulic conductivity. The model is nearly insensitive to increases in the vertical conductance of the top layer (fig. $6 B$ ) because the initial estimates of vertical hydraulic conductivity of the sand and gravel stratified drift of the top layer were already very large; increases in the calibrated value of vertical conductance of the top layer had very little effect on heads or the flow of water between layers 1 and 2 .

Although heads are sensitive to changes in the individual values of recharge and horizontal hydraulic conductivity of the top layer, heads were less sensitive to changes in these parameters when they were varicd simultaneously (fig. 7). Figure 7 shows that an infinite number of combinations of recharge and horizontal hydraulic conductivity of layer 1 are possible that result in a mean error between observed and calculated heads of $0.8 \mathrm{ft}$. Because neither horizontal hydraulic conductivity nor recharge are known precisely, it is not possible to determine a unique combination of these parameters through model calibration. The results have important implications to the delineation of contributing areas for public-supply wells because uncertainty in the true value of each parameter results in a range of possible contributing areas for each well.

\section{Two-Dimensional Model}

The two-dimensional model of the simple flow system consists of a single layer that corresponds generally with coarse-grained sand and gravel stratified drift. The layer extends from the water table to $90 \mathrm{ft}$ below sea level (table 4). The altitude of the base of the layer was chosen because the three-dimensional model indicated that little water flows through the underlying confining unit; therefore, a no-flow boundary was set at $90 \mathrm{ft}$ below sea level. The horizontal grid spacing and lateral boundary conditions of the two-dimensional model are the same as those specified for the top layer of the threedimensional model (fig. 4). The rates of recharge specified for the model were the same as those specified for the calibrated three-dimensional model; or $18.3 \mathrm{in} / \mathrm{yr}$ for the stratified drift and $12.4 \mathrm{in} / \mathrm{yr}$ for cells that underlie ponds. An initial estimate of hydraulic conductivity for each cell of the two-dimensional model was determined by dividing the total transmissivity by the saturated thickness of the top four layers of the calibrated three-dimensional model.

Calculated heads were compared to heads measured at 16 sites in the aquifer. Initial estimates of hydraulic conductivity were reduced over much of the model during calibration. The mean error between the absolute 

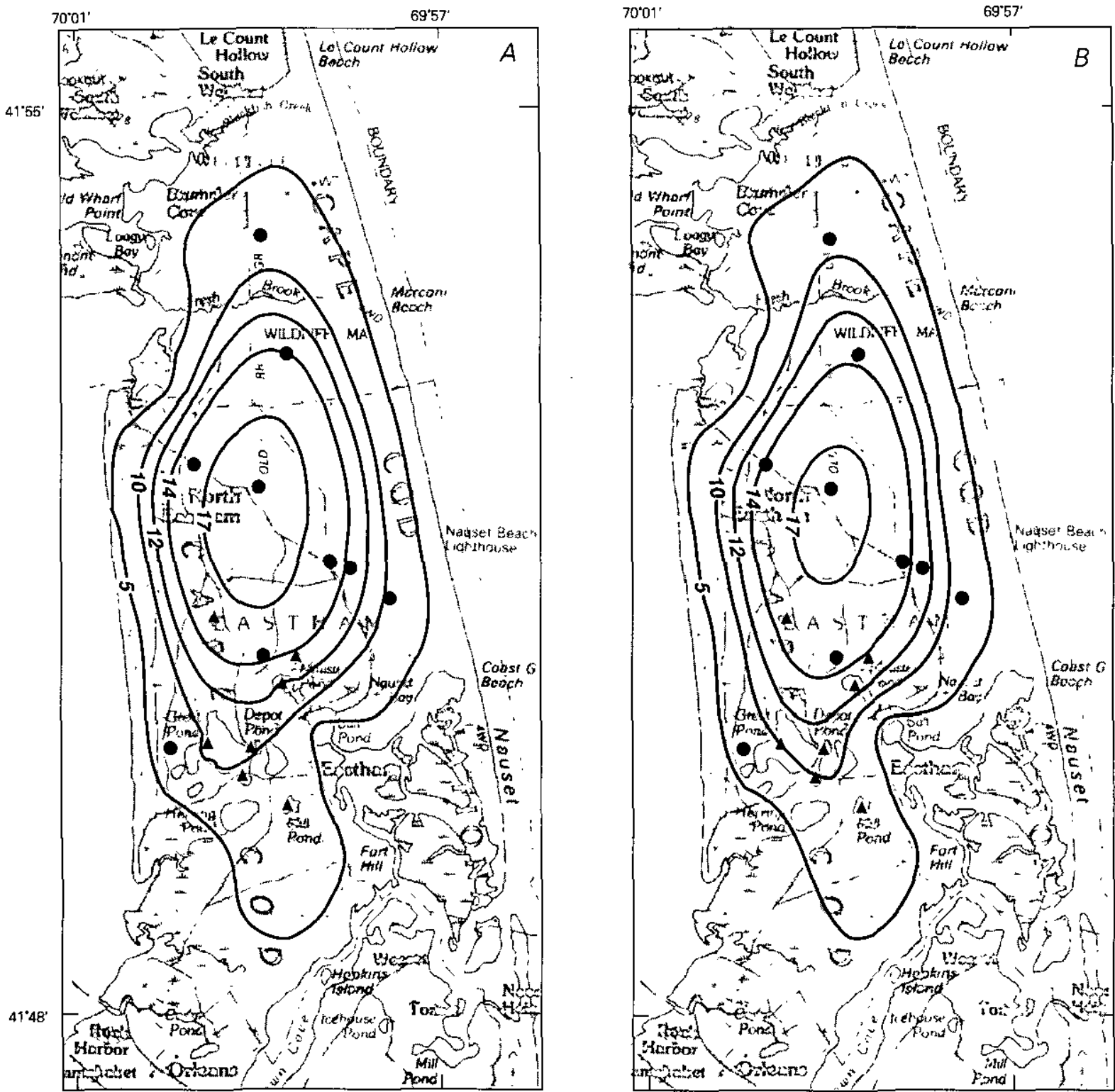

Base from U.S. Geological Survey

Chatham, $1: 100,000,1986$ and

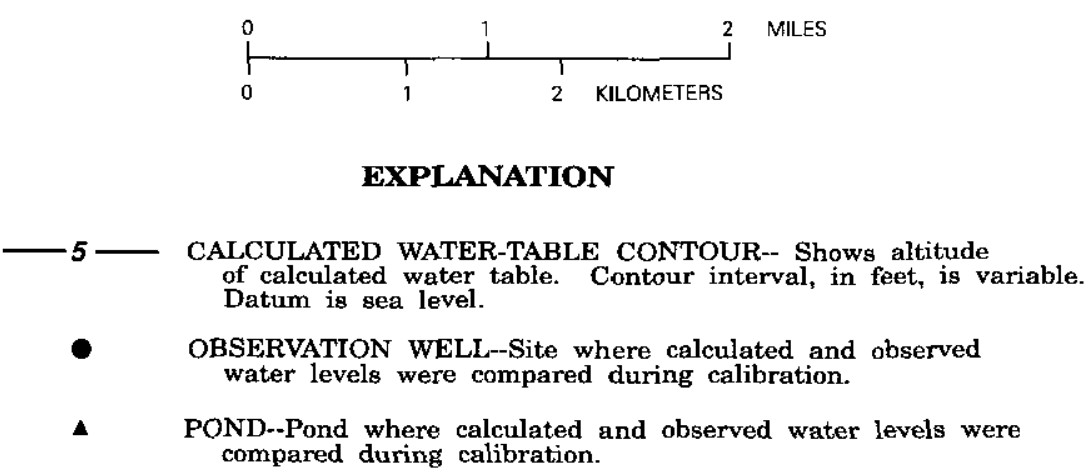

Figure 5. Calculated water-table configurations for $(A)$ the top layer of the three-dimensional model and $(B)$ the two-dimensional model of the simple flow system. 
Table 5. Observed heads and heads calculated by the three- and two-dimensional models of the simple flow system

[W, Wellfleet; E, Eastham; 3-D, three dimensional; 2-D, two dimensional; --, value not calculated by two-dimensional model]

\begin{tabular}{|c|c|c|c|c|c|c|c|c|}
\hline \multicolumn{3}{|c|}{ Model node } & \multirow{2}{*}{$\begin{array}{c}\text { Well } \\
\text { number or } \\
\text { pond name }\end{array}$} & \multirow{2}{*}{$\begin{array}{c}\text { Observed } \\
\text { water level, } \\
\text { in feet above } \\
\text { sea level }\end{array}$} & \multicolumn{2}{|c|}{$\begin{array}{l}\text { Calculated water level, } \\
\text { in feet above sea level }\end{array}$} & \multicolumn{2}{|c|}{$\begin{array}{l}\text { Difference between observed } \\
\text { and calculated head, in feet }\end{array}$} \\
\hline Layer & Row & Column & & & $\begin{array}{c}3-\mathrm{D} \\
\text { model }\end{array}$ & $\begin{array}{c}2-\mathrm{D} \\
\text { model }\end{array}$ & $\begin{array}{c}3-\mathrm{D} \\
\text { model }\end{array}$ & $\begin{array}{c}2-\mathrm{D} \\
\text { model }\end{array}$ \\
\hline 2 & 9 & 32 & W17 & 9.1 & 9.2 & 9.9 & -0.1 & -0.8 \\
\hline 1 & 14 & 37 & W112 & 13.8 & 13.5 & 13.1 & .3 & .7 \\
\hline 2 & 14 & 37 & W113 & 13.7 & 13.4 & -- & .3 & -- \\
\hline 3 & 14 & 37 & W114 & 13.7 & 13.4 & -- & .3 & -- \\
\hline 1 & 29 & 20 & E49 & 16.9 & 15.6 & 14.1 & 1.3 & 2.8 \\
\hline 2 & 29 & 20 & E50 & 16.9 & 15.3 & -- & 1.6 & -- \\
\hline 4 & 29 & 20 & E51 & 17.2 & 15.3 & -- & 1.9 & -- \\
\hline 1 & 35 & 33 & E46 & 17.6 & 18.3 & 17.7 & -.7 & -.1 \\
\hline 2 & 35 & 33 & E47 & 17.6 & 18.3 & -- & -.7 & -- \\
\hline 3 & 35 & 33 & E48 & 17.5 & 18.3 & -- & -.8 & -- \\
\hline 1 & 49 & 48 & E32 & 12.8 & 13.3 & 12.7 & -.5 & .1 \\
\hline 1 & 48 & 44 & E36 & 14.3 & 15.2 & 14.6 & -.9 & -.3 \\
\hline 1 & 75 & 17 & E37 & 8.5 & 8.3 & 7.3 & .2 & 1.2 \\
\hline 1 & 65 & 33 & E39 & 13.9 & 14.2 & 14.4 & -.3 & -.5 \\
\hline 2 & 55 & 55 & $\mathrm{E} 40$ & 8.6 & 9.1 & 8.4 & -.5 & .2 \\
\hline 1 & 81 & 37 & Mill Pond & 10.5 & 8.1 & 8.6 & 2.4 & 1.9 \\
\hline 1 & 65 & 38 & Molls Pond & 13.6 & 13.5 & 13.4 & .1 & .2 \\
\hline 1 & 75 & 31 & Priscilla Pond & 9.3 & 10.1 & 10.7 & -.8 & -1.4 \\
\hline 1 & 78 & 29 & Jemima Pond & 9.7 & 9.7 & 9.9 & .0 & -.2 \\
\hline 1 & 59 & 23 & Briggs Pond & 15.9 & 15.3 & 14.8 & .6 & 1.1 \\
\hline 1 & 64 & 36 & Minister Pond & 12.7 & 11.9 & 12.7 & .8 & .0 \\
\hline 1 & 75 & 23 & Great Pond & 8.6 & 10.0 & 10.1 & -1.4 & -1.5 \\
\hline
\end{tabular}

value of the difference between observed and calculated heads for the calibrated model was $0.8 \mathrm{ft}$, and the mean difference between observed and calculated heads was $0.21 \mathrm{ft}$, indicating no significant systematic bias in the specification of model parameters. Heads calculated by the two-dimensional model compare favorably with observed heads at each of the observation points (table 5) and are similar to those determined for the top layer of the three-dimensional model (fig. $5 B$ ). Total recharge to the aquifer is $22.1 \mathrm{ft}^{3} / \mathrm{s}$, the same as that determined for the three-dimensional model.

A sensitivity analysis completed for the model indicates that calculated heads are sensitive to both recharge and hydraulic conductivity (fig. $6 \mathrm{C}$ ) and that the model is especially sensitive to decreases in hydraulic conductivity. A comparison between the sensitivity of the three-dimensional model to variations in horizontal hydraulic conductivity for the top layer of the model (fig. 6A) and the sensitivity of the two-dimensional model to variations in horizontal hydraulic conductivity for the single-layer model (fig. $6 \mathrm{C}$ ) indicates that the single-layer, two-dimensional model is much more sensitive to changes in horizontal hydraulic conductivity.

\section{Complex Flow System}

Flow models for the complex flow system extend from approximately $1 \mathrm{mi}$ west of Wequaquet Lake in Barnstable to the Bass River area in Yarmouth and from 


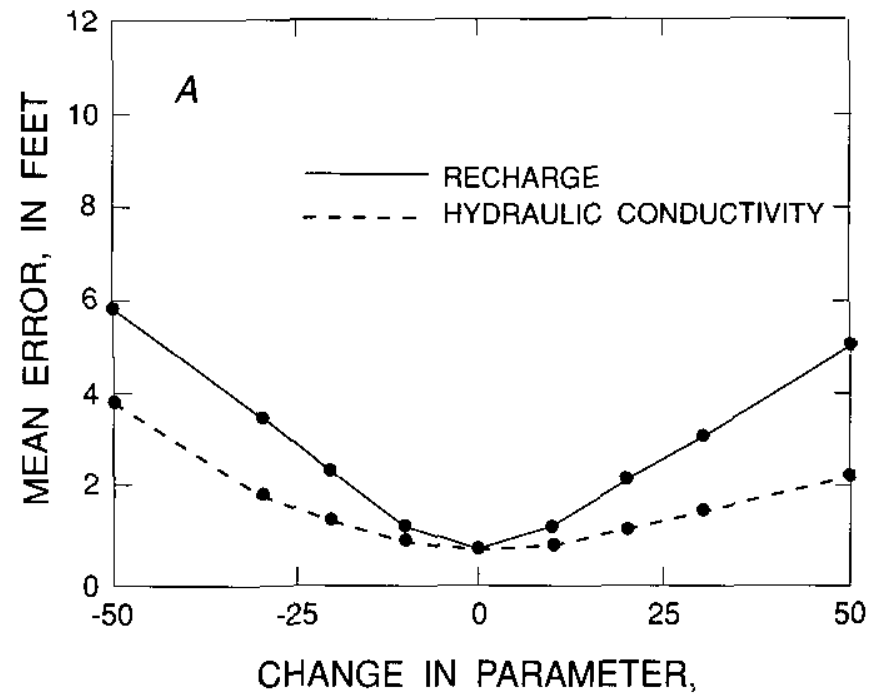

IN PERCENT
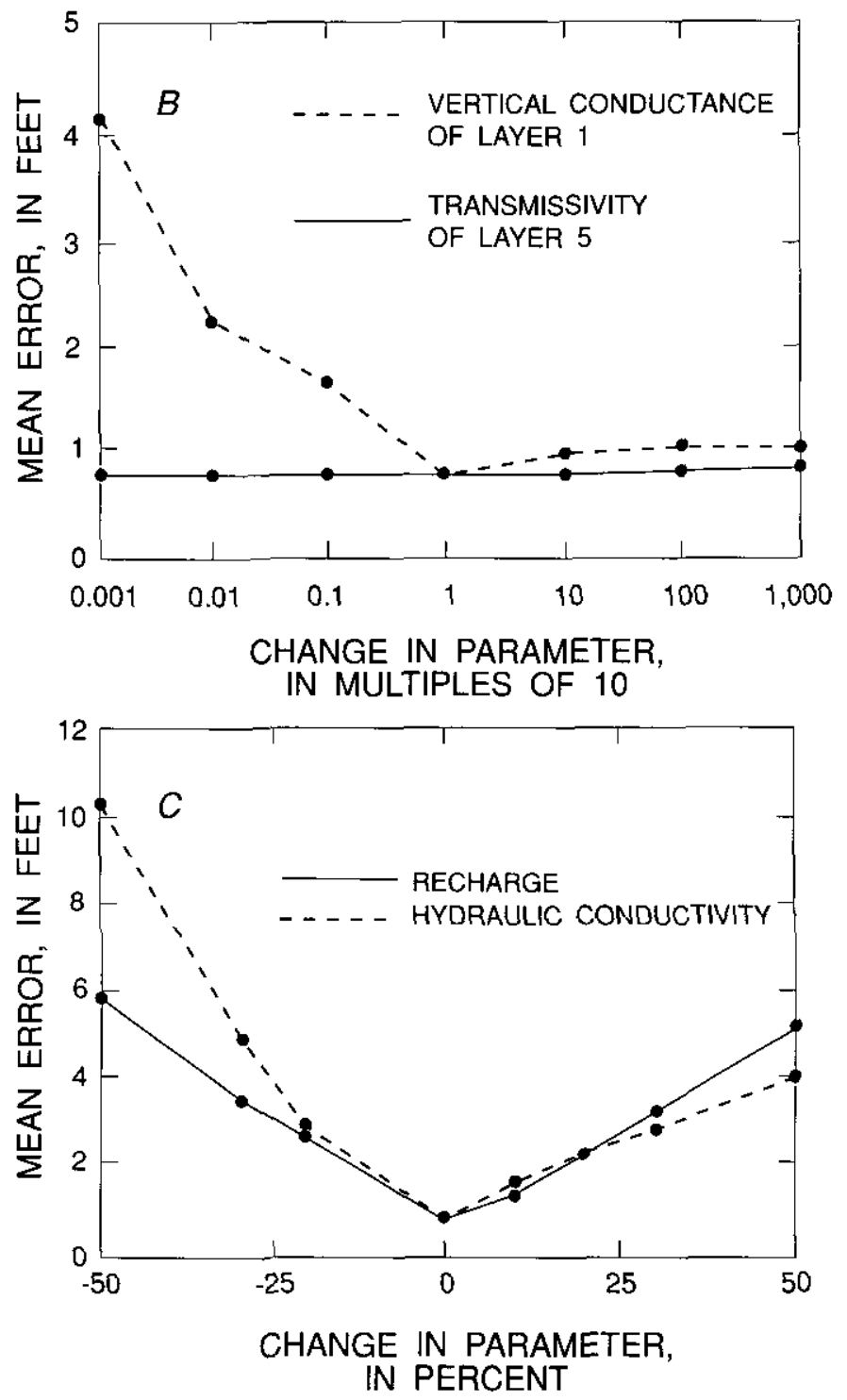

Figure 6. Sensitivity of the three-dimensional model of the simple flow system to changes in (A) recharge and horizontal hydraulic conductivity of the top layer of the model and (B) vertical conductance of layer 1 and transmissivity of layer 5 , and $(C)$ sensitivity of the two-dimensional model of the simple flow system to changes in recharge and horizontal hydraulic conductivity. 


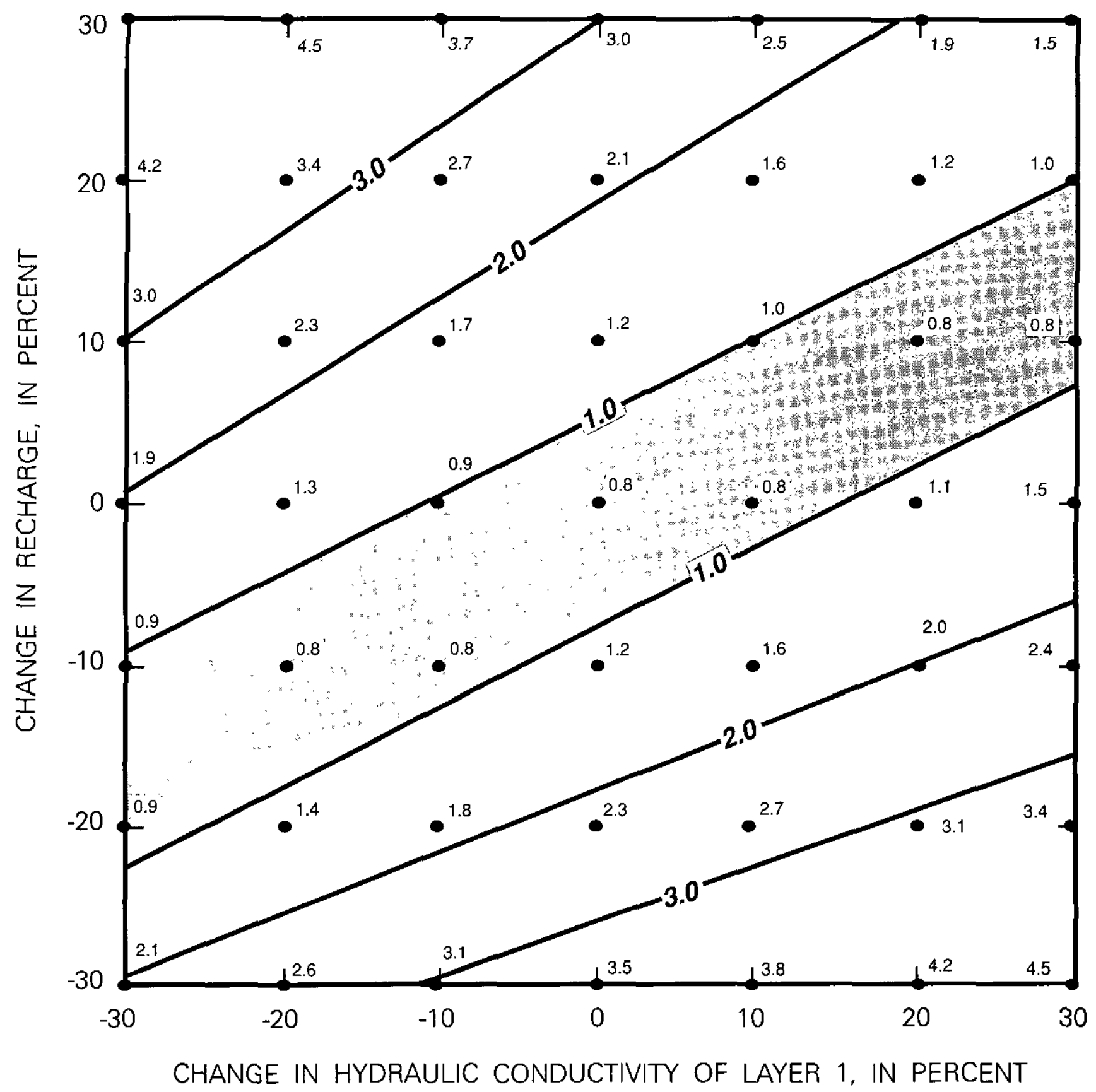

EXPLANATION

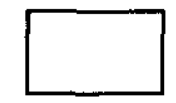

AREA IN WHICH MEAN RESIDUALS BETWEEN OBSERVED AND CALCULATED

HEADS ARE LESS THAN OR EQUAL TO ONE FOO'T

1.0 - LINE OF EQUAL MEAN RESIDUAL BETWEEN OBSERVED AND

CALCULATED HEADS, INTERVAL IS ONE FOOT 2.6 MEAN RESIDUAL BETWEEN OBSERVED AND CALCULATED HEADS FOR
INDIVIDUAL SIMULATION, IN FEET

Figure 7. Mean residuals between observed and calculated heads resulting from simultaneous changes to recharge and hydraulic conductivity of layer l of the three-dimensional flow model for the simple flow system. 
Nantucket Sound north to Cape Cod Bay (fig. 8). The modeled area includes several existing public-supply wells for which contributing areas are delineated in later sections of this report.

\section{Conceptual Model of Ground-Water Flow}

The following statements and assumptions describe the conceptual model of the complex flow system.

1. The flow system is bounded in the north by dune, marsh, swamp, lake, and moraine deposits, which are not favorable areas for groundwater development. South of the moraine, the flow system consists of three units in Barnstable and two units in Yarmouth. In Barnstable, these units are an upper sand and gravel unconfined aquifer, a middle, discontinuous finegrained confining unit of silt and clay, and a lower semiconfined sand aquifer. In Yarmouth, these units are an upper, unconfined aquifer grading downward from sand and gravel to fine sand and silt and an underlying confining unit of silt and clay. Discontinuous lenses of very fine to fine sand, silt, and clay can be found in the aquifers of both towns.

2. The flow system is bounded laterally by saltwater discharge areas at Cape Cod Bay, the Bass River, and Nantucket Sound (fig. 3). The system is bounded to the west by a ground-waterflow line drawn perpendicular to the watertable contours constructed from measurements made on October 14, 1987 (fig. 3), and to the northeast by a ground-water divide between the complex and adjoining flow systems. It is assumed that the flow line and ground-water divide are unaffected by ground-water withdrawals from the system. The flow system is underlain by impermeable, crystalline bedrock.

3. The distribution of ground-water recharge to the water table is nonuniform and consists of precipitation and wastewater return flow. Ground-water withdrawals for public supply are redistributed within and returned to the flow system through septic systems and a wastewater-treatment facility.

4. Ground-water flow is virtually horizontal in most parts of the aquifers and is vertical in the confining unit of Bamstable. Vertical flow com- ponents in the aquifers, however, occur near ground-water divides and discharge boundaries (coastal areas, wells, streams, and ponds) and in the vicinity of discontinuous lenses of very fine to fine sand, silt, and clay.

\section{Three-Dimensional Model}

Hydrogeologic data, well-design characteristics, and the conceptual model of ground-water flow were used to develop the three-dimensional model of the simple flow system. The model was calibrated to heads measured in the flow system during average water-level conditions.

\section{Grid}

The three-dimensional model consists of eight layers (table 6) that were chosen on the basis of the lithology of the flow system and the location of the screenedinterval of public-supply wells (many of which are screened at altitudes of 0 to $50 \mathrm{ft}$ below sea level). The layers represent as closely as possible the sloping contact between the upper sand and gravel aquifer and middle confining unit of Barnstable. The horizontal grid consists of 127 rows and 156 columns (fig. 8). Grid cells range in size from $264 \mathrm{ft}$ by $264 \mathrm{ft}$ to $1,320 \mathrm{ft}$ by $1,320 \mathrm{ft}$. The smallest grid size is near public-supply wells in Barnstable; the largest is in Yarmouth where head data is limited.

\section{Boundary Conditions}

Specified-head boundaries were used to simulate saltwater discharge areas at Cape Cod Bay, the Bass River, and Nantucket Sound (fig. 8). Beneath the Bass River and Nantucket Sound, specified-head boundaries were used only in the top layer of the model. Beneath Cape Cod Bay, however, specified-head boundaries were used in layers 1 through 5 to correspond to the location of offshore discharge (determined from bathymetric maps of the bay). Active cells underlie all specified-head boundaries and extend to the eighth layer of the model. Inactive cells were specified for cells that lie above specified-head boundaries in Cape Cod Bay. Equivalent freshwater heads were determined for specified-head boundaries according to equation 1 .

A ground-water-flow line along the western edge of the model was used to separate the modeled area from the remainder of the West Cape flow cell. Inactive (no- 


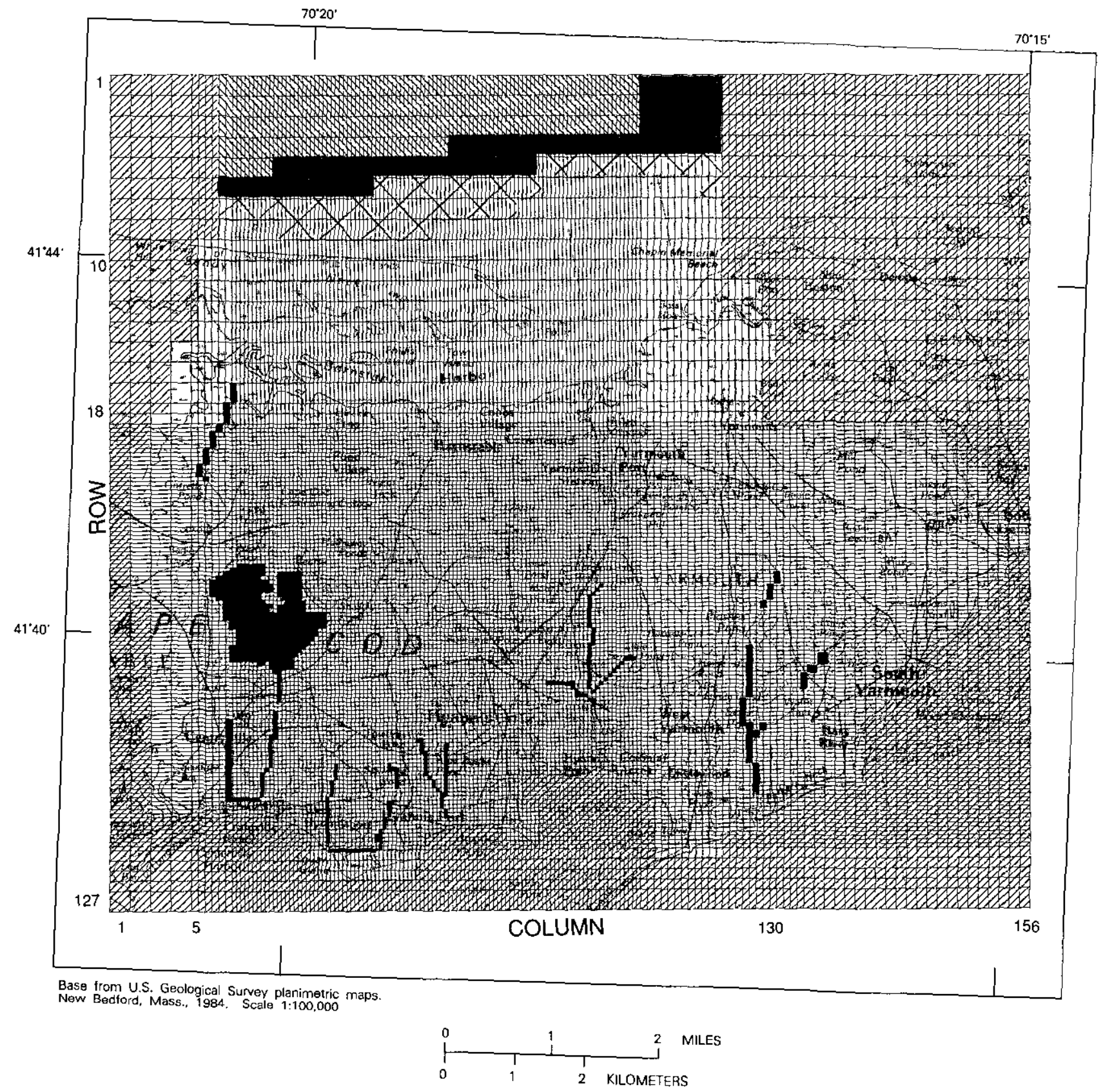

EXPLANATION

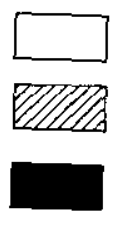

ACTIVE CELL

INACTIVE CELL

HEAD-DEPENDENT FLUX

CELL--At streams and Wequaquet Lake.

SPECIFIED-HEAD CELL--Constant

head at saltwater boundaries.

$\square$ LAYER 1
LAYYER 2
LAYER 3 AND 4
LAYER 5

Figure 8. Model grid and lateral boundary conditions for the three- and two-dimensional models of the
complex flow system. (Boundary simulated in layer 1 of the two-dimensional for layers 2 through 5 of the three-dimensional model are 
Table 6. Vertical layering, horizontal hydraulic conductivity, and vertical conductance of the calibrated three- and two-dimensional flow models of the complex flow system

$[--$, vertical conductance was not specified for the bottom layer of the three-dimensional model or the single layer of the two-dimensional model]

\begin{tabular}{ccc}
\hline $\begin{array}{c}\text { Model } \\
\text { layer } \begin{array}{c}\text { Altitude of layer } \\
\text { bottom, in feet } \\
\text { below sea level }\end{array}\end{array} \begin{array}{c}\text { Horizontal hydraulic } \\
\text { conductivity, in } \\
\text { feet per day }\end{array}$ & $\begin{array}{c}\text { Vertical } \\
\text { conductance, } \\
\text { in day }\end{array}$ \\
\hline
\end{tabular}

Three-dimensional model

$\begin{array}{rrrr}1 & 10 & 50-250^{1} & 0.0001-1.0 \\ 2 & 20 & 0.001-200 & 0.0001-1.0 \\ 3 & 30 & 0.001-200 & 0.0001-1.0 \\ 4 & 40 & 0.001-200 & 0.0001-1.0 \\ 5 & 60 & 0.001-200 & 0.0001-1.0 \\ 6 & 110 & 0.001-200 & 0.0001-1.0 \\ 7 & 200 & 10-30 & 0.00001-.03 \\ 8 & 250-500 & 0.01-30 & --\end{array}$

Two-dimensional model
$1 \quad 200-500$
$10-100$

\begin{abstract}
${ }^{1}$ Grid cells underlying ponds were assigned a horizontal hydraulic conductivity of 50,000 feet per day.
\end{abstract}

flow) cells were specified to the west of the flow line in all eight layers. Water-table altitudes are sparse where the western flow line is drawn, and some error is likely in the position of the flow line and in the location of the western no-flow boundary. Inactive cells also were specified for all eight layers along the northeast section of the model where a natural ground-water divide separates the flow system from the adjoining flow cell.

The top of the model is bounded by active cells that receive ground-water recharge. Recharge from precipitation has been estimated to average $18.9 \mathrm{in} / \mathrm{yr}$ in Barnstable and Yarmouth (LeBlanc and others, 1986, pl. 2). This recharge rate was used as the base value to the model. Recharge was reduced to $15.7 \mathrm{in} / \mathrm{yr}$ for cells that underlie ponds to account for evaporation losses from pond surfaces. No recharge was specified for areas of the model coincident with marshes and swamps because they are assumed to be areas of ground-water discharge. Residential and commercial areas of Barnstable and
Yarmouth receive water from the Bamstable Water Company, the Barnstable Fire District, the Centerville and Osterville Water Company, and the Yarmouth Water Company. Most of Barnstable and Yarmouth is unsewered, and water that is supplied to the residences, businesses, and industries in these towns is retumed to the aquifer through septic systems. The amount of return flow reaching the aquifer in unsewered areas was estimated to be the 1987 average daily volume of water supplied to these areas (less that amount removed by sewers) divided by the total area receiving the supply. The unsewered area within each water district was assumed to be the urban areas shown on USGS 7.5minute topographic maps. Estimates of return flow ranged from 3 to $6 \mathrm{in} / \mathrm{yr}$ and were added to the base value of precipitation recharge.

Water discharged to sewers is returned to the aquifer through infiltration beds at a wastewater-treatment facility in Barnstable. In 1987, average daily discharge from the facility was $1.3 \mathrm{Mgal}$; all wastewater was assumed to infiltrate to the water table. The yearly recharge of wastewater, 293 in., was determined by division of the 1987 discharge of wastewater by the area of the model cells underlying the infiltration beds.

Ground-water pumping was simulated at 12 publicsupply wells (table 7) at rates equal to those measured on October 14, 1987.

The bottom of the model is a no-flow bedrock boundary. The altitudes of the base of the cells in the lowest layer of the model are equal to the altitude of the bedrock surface as determined from seismic-refraction data (Oldale, 1974a, 1974b) and from borehole logs available in the Massachusetts office of the U.S. Geological Survey.

Several small streams in the modeled area receive ground-water discharge. The rate of discharge to the streams depends on the difference between heads in the stream and the underlying aquifer, the altitude of the streambed, and the conductance of streambed sediments. No determination of the characteristics of the streams was made during this investigation; however, visual inspections and conversations with water suppliers and town personnel indicate that local streams are generally less than $5 \mathrm{ft}$ wide, less than $1 \mathrm{ft}$ deep, have sandy streambeds, and flow intermittently throughout the year. 
Streams were modeled as head-dependent flux boundaries that can only receive ground-water discharge. Streambed conductance was determined for each stream cell by the following equation:

$$
C=\frac{K L W}{M}
$$

where
$C$ is streambed conductance, in square feet per day;
$K \quad$ is vertical hydraulic conductivity of the streambed, in feet per day;
$L \quad$ is total length of stream in the cell, in feet;
$W \quad$ is stream width, in fect; and
$M \quad$ is streambed thickness, in feet.

Streambed sediments were assumed to consist of the same material as the underlying aquifer. Because the aquifer consists of sand and gravel in the area of the streams, a ratio of vertical to horizontal hydraulic conductivity of 1:5 was used, which is consistent with the generalized values of the ratio of the vertical to

Table 7. Pumping rates measured on October 14 , 1987, for 12 public-supply wells in Barnstable and Yarmouth, Massachusetts

[All well screens were simulated in the single layer of the twodimensional model; USGS, U.S. Geological Survey; B, Barnstable; Y, Yarmouth]

\begin{tabular}{|c|c|c|c|c|c|}
\hline \multicolumn{3}{|c|}{ Model cell } & \multirow{2}{*}{$\begin{array}{c}\text { Local } \\
\text { well } \\
\text { name }\end{array}$} & \multirow{2}{*}{$\begin{array}{c}\text { USGS } \\
\text { well } \\
\text { identifier }\end{array}$} & \multirow{2}{*}{$\begin{array}{l}\text { Pumping } \\
\text { rate } \\
\text { (cubic feet } \\
\text { per day) }\end{array}$} \\
\hline Layer & Row & Column & & & \\
\hline 1 & 61 & 77 & BWC MD1 & B 387 & 25,400 \\
\hline 2 & 60 & 79 & BWC MD2 & B 383 & 65,500 \\
\hline 1 & 55 & 77 & BWC MD4 & B 402 & 65,500 \\
\hline 5 & 110 & 48 & BWC HY & В 229 & 60,200 \\
\hline 5 & 108 & 49 & BWC SI & В 384 & 89,600 \\
\hline 4 & 48 & 38 & BFD 3 & B 416 & 31,300 \\
\hline 1 & 52 & 53 & $S$ and $G$ & B 497 & 25,400 \\
\hline 4 & 48 & 146 & YWC 6-8 & Y 53 & 25,300 \\
\hline 2 & 62 & 129 & YWC 11 & Y 63 & 55,800 \\
\hline 3 & 65 & 117 & YWC 13 & Y 58 & 89,400 \\
\hline 5 & 35 & 142 & YWC 15 & Y 126 & 96,300 \\
\hline 5 & 74 & 113 & YWC 17 & Y 195 & 58,800 \\
\hline
\end{tabular}

horizontal hydraulic conductivity for medium sand to gravel (table 3). Streambed thickness and width were assumed to be 1 and $5 \mathrm{ft}$, respectivcly, and streambed altitudes were estimated from topographic maps.

Wequaquet Lake was modeled as a head-dependent fux boundary. The altitude of the lake was set at $33.7 \mathrm{ft}$ above sea level, which is the altitude at which it is maintained by the town of Barnstable (Charles Millen, Bamstable Natural Resources, oral commun., 1988). The conductance between the bottom sediments of the lake and the underlying aquifer was determined for each lake cell to be the product of the area of the cell multiplied by a leakance term. The leakance term was calculated as the quotient of the vertical hydraulic conductivity of the sediments beneath the lake divided by an assumed distance over which head losses between the aquifer and overlying lake take place. Vertical hydraulic conductivity of lake sediments was assumed to be the same as that of the underlying aquifer, or about one-fifth of the horizontal hydraulic conductivity of the underlying aquifer. Head losses between the aquifer and overlying lake were assumed to take place over a distance of $15 \mathrm{ft}$, which is about one-half the distance from the mean bottom altitude of the lake - $23 \mathrm{ft}$ above sea level (McCann, 1969) - to the altitude of the bottom of layer 1 ( $10 \mathrm{ft}$ below sea level).

\section{Hydraullc Properties}

Estimates of horizontal hydraulic conductivity and vertical conductance were made by comparison of lithologic logs of more than 370 test holes in the modeled area to generalized values of hydraulic conductivity (table 3 ). Each log was divided into intervals that correspond to the eight layers of the model. A value of horizontal hydraulic conductivity and vertical conductance for each interval of the log was then determined from equations 2 and 3 . Cells in the top layer of the model that underlic ponds were assigned a horizontal hydraulic conductivity of $50,000 \mathrm{ft} / \mathrm{d}$. Small ponds, covering only a fraction of a grid cell, were not modeled.

Sediments of the fine-grained unit that underlies stratified drift in eastem Barnstable were assigned a' horizontal and vertical hydraulic conductivity of $0.01 \mathrm{ft} / \mathrm{d}$. Lacustrine deposits near and beneath Cape Cod Bay are thought to be of the same origin as those 
of Eastham and were assigned horizontal and vertical hydraulic conductivities of $0.001 \mathrm{ft} / \mathrm{d}$. Larger hydraulic conductivities were assigned to sediments of the finegrained unit in eastem Bamstable than to those underlying Cape Cod Bay because they are less compact and are generally coarser than those of the simple flow system for which hydraulic conductivity has been estimated by means of permeameter tests.

\section{Callbration and Sensilivity}

The model was calibrated by comparison of calculated heads to heads measured at 63 observation wells and 3 ponds on October 14, 1987. Heads at this time were used for model calibration because they are considered representative of average (steady-state) conditions. Initial estimates of hydraulic conductivity for cells in layers 3 through 6 of the model and for cells that underlie moraine were reduced during model calibration; however, recharge was not adjusted. Generally, horizontal hydraulic conductivity and vertical conductance decrease as the depth of each model layer increases (table 6), which is consistent with the lithology of the flow system.

A map of calculated water-table altitudes for the top layer of the model is shown in figure 9. Generally, agreement between observed and calculated heads is close at each of the observation points (table 8). The mean error of the absolute value of observed heads minus calculated heads is $1.7 \mathrm{ft}$, which corresponds to approximately 5 percent of the total relief of the water table in the flow system. The errors are distributed around a mean value of $0.53 \mathrm{ft}$, indicating that calculated heads are generally lower than observed heads. This positive bias is most likely the result of high values specified for the hydraulic conductivity of the finegrained unit consisting of silt and clay in eastem Barnstable. In a second simulation, the horizontal hydraulic conductivity and vertical conductance of these silt and clay sediments were reduced by an order of magnitude to the values used for fine-grained sediments beneath Cape Cod Bay; the resulting mean error of the absolute value of observed heads minus calculated heads was $1.8 \mathrm{ft}$. Although this mean error was not substantially different from that determined for the first simulation $(1.7 \mathrm{ft})$, the error between observed heads and calculated heads for the second simulation was $-0.43 \mathrm{ft}$, indicating that calculated heads were now generally higher than the observed heads. Results of these two simulations indicate that the true value of hydraulic conductivity of these silt and clay sediments lies somewhere between the two values simulated.

Total steady-state inflow to the model is $79.4 \mathrm{ft}^{3} / \mathrm{s}$ (table 9), 79 percent of which discharges to specifiedhead, coastal boundaries. Less than 2 percent of the inflow discharges through lacustrine deposits that underlie Cape Cod Bay to specified-head cells located deeper than layer 1. Fifty-two percent of the total inflow discharges to specified-head cells along Nantucket Sound, from the southwestern edge of the model to the Bass River. Nantucket Sound receives much of the discharge from the system because the most transmissive parts of the aquifer extend south from the moraine to Nantucket Sound. Nearly 10 percent of the total inflow reaches the bottom layer of the model, which extends from $200 \mathrm{ft}$ below sea level downward to the top of bedrock.

A sensitivity analysis was completed for the threedimensional model to determine the response of calculated heads and flow rates to changes in the values of model parameters. As noted above, the horizontal and vertical hydraulic conductivities assigned for silt and clay in the central part of the study area significantly affect calculated heads. Model results also were sensitive to changes in the recharge rate and hydraulic conductivity of the top layer of the model (fig.10A).

Sensitivity of calculated heads to the value of the conductance term for the head-dependent flux boundaries used to represent Wequaquet Lake and streams also was tested. Each of the conductance terms was increased and decreased by an order of magnitude in four separate simulations. Computed heads were found to be less sensitive to changes in the conductance of the lake sediments than to changes in the conductance of streambed sediments. Mean errors for these four simulations ranged from 1.7 to $1.9 \mathrm{ft}$. The discharge of ground water to streams was affected by changes in the values of the conductance term for stream cells. Ground-water discharge to streams increased from 6.9 to $9.9 \mathrm{ft}^{3} / \mathrm{s}$ when stream conductances were increased by an order of magnitude; ground-water discharge decreased to $1.8 \mathrm{ft}^{3} / \mathrm{s}$ when stream conductances were decreased by an order of magnitude. The discharge of water to Weqauquet Lake was unaffected by changes in the value of the conductance term used to represent the lake sediments. Although the conductance terms used to represent the lake sediments are not well defined, these 


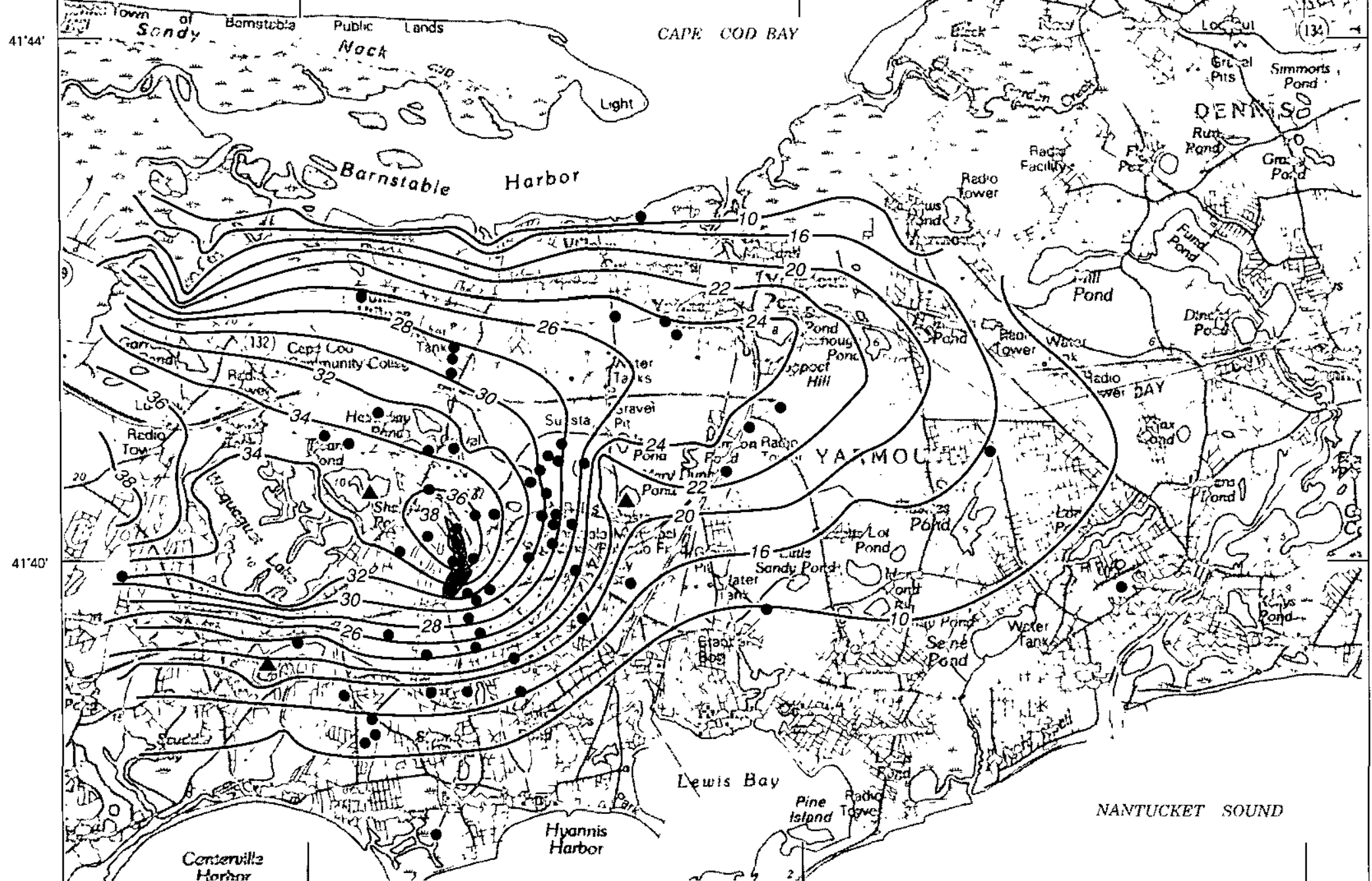

Base from U.S. Geological Survey planimetric maps.

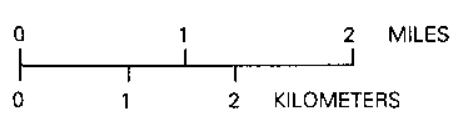

\section{EXPLANATION}

WASTEWATER-TREATMENT-FACILITY INFILTRATION BEDS

CALCULATED WATER-TABLE CONTOUR--Shows altitude of calculated water table. Contour interval, in feet, is variable. Datum is sea level.

- OBSERVATION WELL--Site where calculated and observed water levels were compared during calibration.

- POND.-Pond where calculated and observed water levels were compared during calibration.

Figure 9. Calculated water-table configuration for the top layer of the three-dimensional model of the complex flow system. 
Table 8. Observed heads and heads calculated by the three- and two-dimensional models of the complex flow system

[B, Barnstable; Y, Yarmouth; 3-D, three-dimensional; 2-D, two-dimensional]

\begin{tabular}{|c|c|c|c|c|c|c|c|c|}
\hline \multirow{2}{*}{ Layer } & \multicolumn{2}{|c|}{ Model node } & \multirow{2}{*}{$\begin{array}{c}\text { Well } \\
\text { number or } \\
\text { pond name }\end{array}$} & \multirow{2}{*}{$\begin{array}{c}\text { Observed } \\
\text { water level, } \\
\text { in feet above } \\
\text { sea level }\end{array}$} & \multicolumn{2}{|c|}{$\begin{array}{l}\text { Calculated water level, } \\
\text { in feet above sea level }\end{array}$} & \multicolumn{2}{|c|}{$\begin{array}{l}\text { Difference between observed } \\
\text { and calculated head, in feet }\end{array}$} \\
\hline & Row & Column & & & $\begin{array}{l}3-\mathrm{D} \\
\text { model }\end{array}$ & $\begin{array}{l}2-\mathrm{D} \\
\text { model }\end{array}$ & $\begin{array}{c}3-\mathrm{D} \\
\text { model }\end{array}$ & $\begin{array}{l}2-\mathrm{D} \\
\text { model }\end{array}$ \\
\hline 1 & 71 & 63 & B 434 & 33.48 & 30.33 & 30.22 & 3.15 & 3.26 \\
\hline 1 & 50 & 27 & B 435 & 34.25 & 34.39 & 34.96 & -.14 & -.71 \\
\hline 1 & 70 & 40 & B 437 & 34.67 & 34.25 & 35.52 & .42 & -.85 \\
\hline 1 & 88 & 44 & B 439 & 26.76 & 24.66 & 23.96 & 2.10 & 2.80 \\
\hline 1 & 80 & 44 & B 440 & 31.88 & 30.15 & 29.97 & 1.73 & 1.91 \\
\hline 1 & 86 & 21 & B 441 & 26.73 & 22.68 & 25.33 & 4.05 & 1.40 \\
\hline 1 & 96 & 31 & B 442 & 16.96 & 17.47 & 17.63 & -.51 & -.67 \\
\hline 1 & 71 & 53 & В 444 & 37.38 & 36.51 & 36.92 & .87 & .46 \\
\hline 1 & 60 & 47 & B 445 & 36.29 & 36.17 & 36.86 & .12 & -.57 \\
\hline 1 & 64 & 69 & В 447 & 29.72 & 27.79 & 29.20 & 1.93 & .52 \\
\hline 1 & 74 & 71 & B 448 & 26.59 & 24.69 & 24.25 & 1.90 & 2.34 \\
\hline 1 & 83 & 72 & B 449 & 20.65 & 20.32 & 17.82 & .33 & 2.83 \\
\hline 1 & 58 & 64 & B 450 & 32.43 & 30.96 & 32.42 & 1.47 & .01 \\
\hline 1 & 64 & 54 & B 451 & 36.20 & 36.09 & 36.29 & .11 & -.09 \\
\hline 1 & 78 & 55 & B 452 & 32.06 & 31.29 & 30.32 & .77 & 1.74 \\
\hline 1 & 87 & 53 & В 455 & 24.91 & 25.09 & 23.33 & -.18 & 1.58 \\
\hline 1 & 90 & 60 & B 456 & 21.23 & 21.10 & 18.70 & .13 & 2.53 \\
\hline 1 & 66 & 51 & B 458 & 37.28 & 37.70 & 37.64 & -.42 & -.36 \\
\hline 1 & 73 & 50 & B 459 & 33.79 & 36.34 & 37.70 & -2.55 & -3.91 \\
\hline 1 & 68 & 45 & B 470 & 33.95 & 36.27 & 37.09 & -2.32 & -3.14 \\
\hline 1 & 64 & 57 & B 471 & 35.14 & 34.83 & 35.12 & .31 & .02 \\
\hline 1 & 78 & 52 & B 472 & 31.46 & 32.22 & 32.06 & -.76 & -.60 \\
\hline 1 & 82 & 53 & B 460 & 29.74 & 28.90 & 27.43 & .84 & 2.31 \\
\hline 1 & 95 & 51 & B 461 & 17.69 & 18.37 & 17.31 & -.68 & .38 \\
\hline 1 & 95 & 45 & В 469 & 20.36 & 19.03 & 18.29 & 1.33 & 2.07 \\
\hline 4 & 85 & 54 & B 463 & 25.40 & 24.17 & 24.61 & 1.23 & 0.79 \\
\hline 1 & 77 & 57 & B 464 & 31.81 & 31.16 & 30.05 & .65 & 1.76 \\
\hline 2 & 95 & 62 & B 467 & 15.39 & 15.76 & 13.95 & -.37 & 1.44 \\
\hline 1 & 39 & 50 & B 473 & 31.50 & 29.73 & 30.68 & 1.77 & .82 \\
\hline 1 & 54 & 66 & В 474 & 31.82 & 29.65 & 31.75 & 2.17 & .07 \\
\hline 1 & 53 & 70 & B 475 & 30.08 & 27.78 & 30.22 & 2.30 & -.14 \\
\hline 2 & 55 & 68 & B 476 & 31.00 & 28.63 & 30.90 & 2.37 & .10 \\
\hline 2 & 56 & 66 & B 477 & 31.93 & 29.62 & 31.68 & 2.31 & .25 \\
\hline 2 & 60 & 66 & B 478 & 31.59 & 29.39 & 31.39 & 2.20 & .20 \\
\hline 1 & 51 & 32 & В 479 & 34.74 & 34.37 & 35.12 & .37 & -.38 \\
\hline 1 & 46 & 38 & B 480 & 32.80 & 32.91 & 33.47 & -.11 & -.67 \\
\hline 1 & 66 & 68 & B 481 & 30.45 & 28.35 & 29.26 & 2.10 & 1.19 \\
\hline 1 & 70 & 68 & B 482 & 28.46 & 27.53 & 27.83 & .93 & .63 \\
\hline 1 & 64 & 66 & В 483 & 31.19 & 30.04 & 30.81 & 1.15 & .38 \\
\hline 1 & 66 & 71 & В 484 & 28.96 & 25.93 & 27.63 & 3.03 & 1.33 \\
\hline
\end{tabular}


Table 8. Observed heads and heads calculated by the three- and two-dimensional models of the complex flow system-Continued

\begin{tabular}{|c|c|c|c|c|c|c|c|c|}
\hline \multirow{2}{*}{ Layer } & \multicolumn{2}{|c|}{ Model node } & \multirow{2}{*}{$\begin{array}{c}\text { Well } \\
\text { number or } \\
\text { pond name }\end{array}$} & \multirow{2}{*}{$\begin{array}{c}\text { Observed } \\
\text { water level, } \\
\text { in feet above } \\
\text { sea level }\end{array}$} & \multicolumn{2}{|c|}{$\begin{array}{l}\text { Calculated water level, } \\
\text { in feet above sea level }\end{array}$} & \multicolumn{2}{|c|}{$\begin{array}{l}\text { Difference between observed } \\
\text { and calculated head, in feet }\end{array}$} \\
\hline & Row & Column & & & $\begin{array}{c}3-\mathrm{D} \\
\text { model }\end{array}$ & $\begin{array}{l}2-\bar{D} \\
\text { model }\end{array}$ & $\begin{array}{l}3-\mathrm{D} \\
\text { model }\end{array}$ & $\begin{array}{l}2-\bar{D} \\
\text { model }\end{array}$ \\
\hline 1 & 33 & 91 & B 485 & 22.00 & 24.57 & 26.04 & -2.57 & -4.04 \\
\hline 1 & 30 & 87 & В 486 & 18.77 & 23.99 & 24.14 & -5.22 & -5.37 \\
\hline 1 & 57 & 98 & Y 205 & 26.41 & 22.87 & 27.15 & 3.54 & -.74 \\
\hline 1 & 57 & 73 & B 487 & 28.59 & 25.54 & 27.84 & 3.05 & .75 \\
\hline 1 & 47 & 108 & Y 206 & 24.71 & 23.07 & 29.76 & 1.64 & -5.05 \\
\hline 2 & 51 & 101 & Y 85 & 21.31 & 23.13 & 29.11 & -1.82 & -7.80 \\
\hline 2 & 34 & 50 & В 295 & 28.38 & 28.25 & 27.65 & .13 & .73 \\
\hline 1 & 37 & 50 & B 290 & 30.18 & 29.22 & 29.59 & .96 & .59 \\
\hline 2 & 54 & 42 & B 293 & 35.28 & 33.19 & 35.82 & 2.09 & -.54 \\
\hline 1 & 74 & 80 & B 230 & 19.27 & 18.84 & 20.55 & .43 & -1.28 \\
\hline 6 & 118 & 46 & В 322 & 0.43 & 2.69 & 2.66 & -2.26 & -2.23 \\
\hline 1 & 29 & 78 & B 247 & 21.28 & 24.72 & 23.50 & -3.44 & -2.22 \\
\hline 1 & 52 & 46 & B 292 & 35.33 & 33.73 & 35.27 & 1.60 & .06 \\
\hline 2 & 26 & 36 & В 294 & 19.18 & 26.78 & 21.99 & -7.60 & -2.81 \\
\hline 1 & 84 & 38 & В 306 & 29.07 & 26.98 & 26.74 & 2.09 & 2.33 \\
\hline 6 & 16 & 83 & B 318 & 9.94 & 14.60 & .13 & -4.66 & 9.81 \\
\hline 1 & 81 & 102 & Y 123 & 8.52 & 9.84 & 8.85 & -1.32 & -.33 \\
\hline 4 & 100 & 33 & В 226 & 14.23 & 14.59 & 14.14 & -.36 & .09 \\
\hline 2 & 103 & 33 & В 227 & 11.93 & 12.03 & 11.24 & -.10 & .69 \\
\hline 2 & 102 & 33 & В 368 & 12.40 & 12.92 & 12.12 & -.52 & .28 \\
\hline 1 & 54 & 130 & Y 89 & 18.35 & 15.94 & 22.45 & 2.41 & -4.10 \\
\hline 1 & 78 & 140 & Y 96 & 5.46 & 5.77 & 8.01 & -.31 & -2.55 \\
\hline 2 & 72 & 3 & B 254 & 35.56 & 33.01 & 34.27 & 2.55 & 1.29 \\
\hline 1 & 60 & 33 & $\begin{array}{r}\text { Shallow } \\
\text { Pond }\end{array}$ & 34.63 & 34.77 & 35.35 & -.14 & -.72 \\
\hline 1 & 88 & 21 & Long Pond & 25.80 & 22.06 & 23.66 & 3.74 & 2.14 \\
\hline 1 & 62 & 80 & $\begin{array}{l}\text { Mary Dunn } \\
\text { Pond }\end{array}$ & 23.96 & 20.06 & 23.72 & 3.90 & .24 \\
\hline
\end{tabular}

sensitivity tests indicate that the parameter does not significantly affect calculated heads in the aquifer or the rate of ground-water discharge to the lake.

Calculated heads were also found to be fairly insensitive to the inclusion of the first seven rows of the model, which are in Cape Cod Bay and simulate offshore discharge through lacustrine deposits in layers 2 through 5. The exclusion of these cells resulted in a change of $0.1 \mathrm{ft}$ in the mean error. A simulation also was made on the basis of the 1987 average daily pumping rate of all supply wells in the study area. Model heads determined for that simulation did not differ significantly from those determined on the basis of the pumping rates of October 14, 1987. Calculated heads along the western boundary of the model, where a groundwater-flow line was used to separate the modeled area from the remainder of the flow system, were also found to be insensitive to the pumping rates simulated at each well; therefore, the uncertainty associated with the boundary location is assumed to be insignificant to the delineation of contributing areas for simulated wells. 
Table 9. Calculated water budgets for the threeand two-dimensional flow models of the complex flow system

[All values are cubic foot per second]

\begin{tabular}{|c|c|c|}
\hline & $\begin{array}{c}\text { Three- } \\
\text { dimensional } \\
\text { model }\end{array}$ & $\begin{array}{c}\text { Two- } \\
\text { dimensional } \\
\text { model }\end{array}$ \\
\hline \multicolumn{3}{|l|}{ Inflow } \\
\hline Recharge & 77.2 & 77.2 \\
\hline $\begin{array}{l}\text { Leakage from } \\
\text { Wequaquet Lake }\end{array}$ & 2.2 & 2.5 \\
\hline Total inflow & 79.4 & 79.7 \\
\hline \multicolumn{3}{|l|}{ Outflow } \\
\hline $\begin{array}{l}\text { Discharge to coastal } \\
\text { boundaries }\end{array}$ & 62.7 & 60.2 \\
\hline $\begin{array}{l}\text { Leakage to Wequaquet } \\
\text { Lake }\end{array}$ & 2.0 & 3.9 \\
\hline Wells & 8.0 & 8.0 \\
\hline Streams & 6.9 & 7.7 \\
\hline Total outflow & 79.6 & 79.8 \\
\hline $\begin{array}{l}\text { Inflow minus outflow } \\
\text { (numerical error) }\end{array}$ & -0.2 & -0.1 \\
\hline
\end{tabular}

\section{Two-Dimensional Model}

The two-dimensional model of the complex flow system consists of a single layer that extends from the water table to bedrock. The horizontal grid spacing is the same as that of the three-dimensional model (fig. 8). Lateral boundary conditions specified for the twodimensional model are the same as those specified for the top layer of the three-dimensional model (fig. 8), but inactive cells were specified for the first seven rows of the model because the three-dimensional model was fairly insensitive to their inclusion. In addition, a noflow boundary was set at the contact between glacial deposits and underlying bedrock. The rate of areal recharge specified for each cell and the pumping rates of simulated wells (table 7) were the same as those specified for the three-dimensional model. An initial estimate of horizontal hydraulic conductivity for each cell of the two-dimensional model was determined by division of the total transmissivity by the saturated thickness of the eight layers of the calibrated three-dimensional model.

Calculated heads were compared to observed heads measured at 66 observation wells and ponds in the study area on October 14, 1987. The mean residual of the absolute value of the difference between observed heads and calculated heads is $1.6 \mathrm{ft}$, and the mean error is $0.03 \mathrm{ft}$, indicating no significant systematic bias in the estimates of model parameters. Agreement between calculated heads and observed heads at each of the observation points is generally close (table 8 ). Water-table contours based on calculated heads are shown in figure 11 .

Total inflow to the model is $79.7 \mathrm{ft}^{3} / \mathrm{s}$ (table 9), which is $0.3 \mathrm{ft}^{3} / \mathrm{s}$ more than total inflow to the threedimensional model. Results of the calibration indicate that approximately $0.8 \mathrm{ft}^{3} / \mathrm{s}$ more water discharges to streams in the two-dimensional model than in the threedimensional model, and net outflow to Wequaquet Lake in the two-dimensional model is greater than the threedimensional model by approximately $1.6 \mathrm{ft}^{3} / \mathrm{s}$. The sensitivity analysis indicates that calculated heads are sensitive to both recharge and hydraulic conductivity (fig. 10B) and are most sensitive to decreases in horizontal hydraulic conductivity.

\section{PARTICLE-TRACKING ANALYSIS OF CONTRIBUTING AREAS}

Tracking of fluid particle pathlines within a groundwater-flow model from areas of recharge to a supply well is the final step in the delineation of the contributing area of a supply well. The simulations reported here were completed to demonstrate the use of particle tracking for delineation of contributing areas and the source of water to public-supply wells, and to assess qualitatively and quantitatively how the location of that area and the source of water are affected by such factors as well location and pumping rate, aquifer heterogeneity, spatial variability of recharge rates, parameter uncertainty, and grid discretization. 

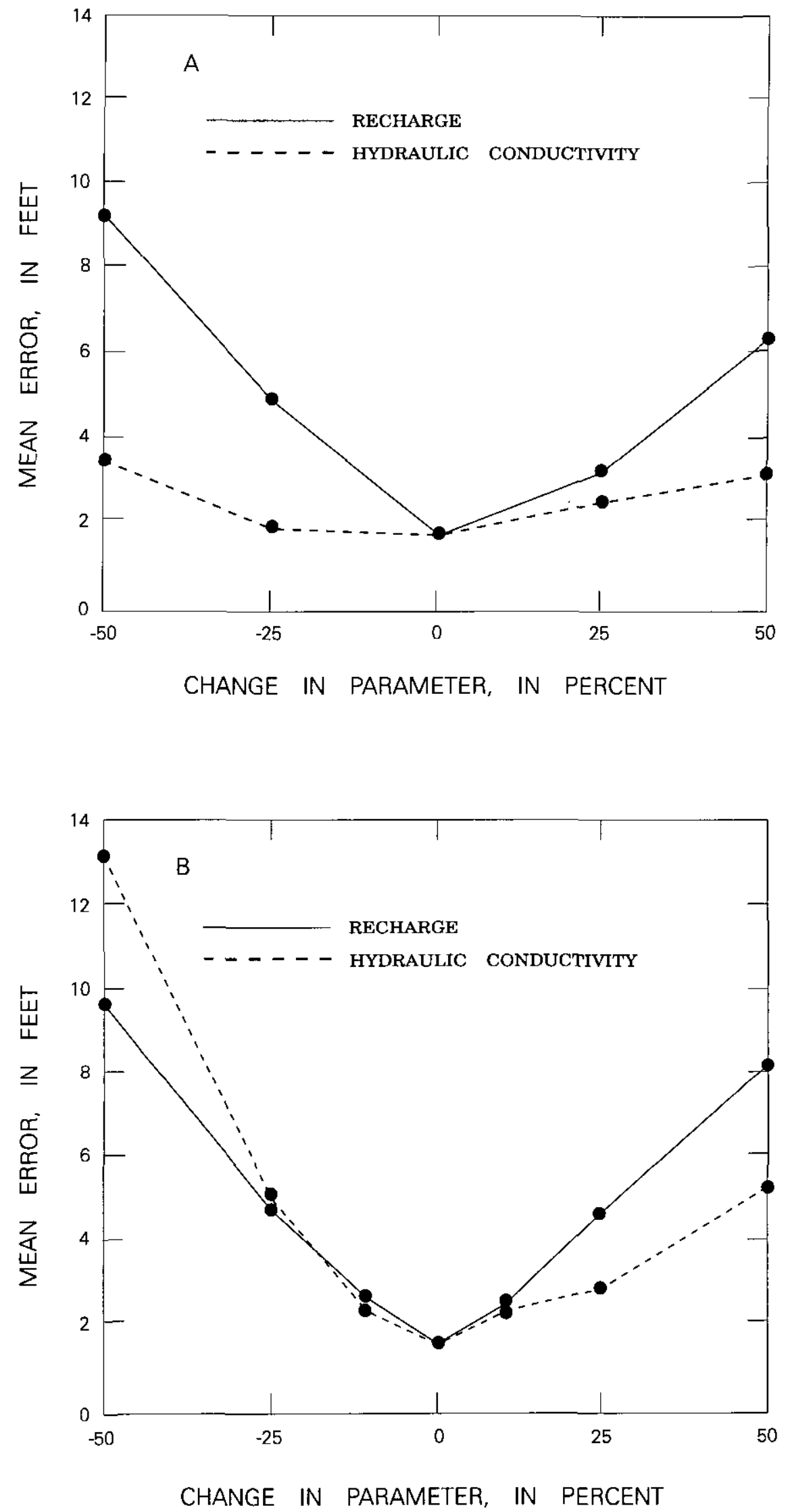

Figure 10. Sensitivity of $(A)$ the three-dimensional model and $(B)$ the two-dimensional model of the complex flow system to changes in recharge and horizontal hydraulic conductivity of layer 1 of each model. 


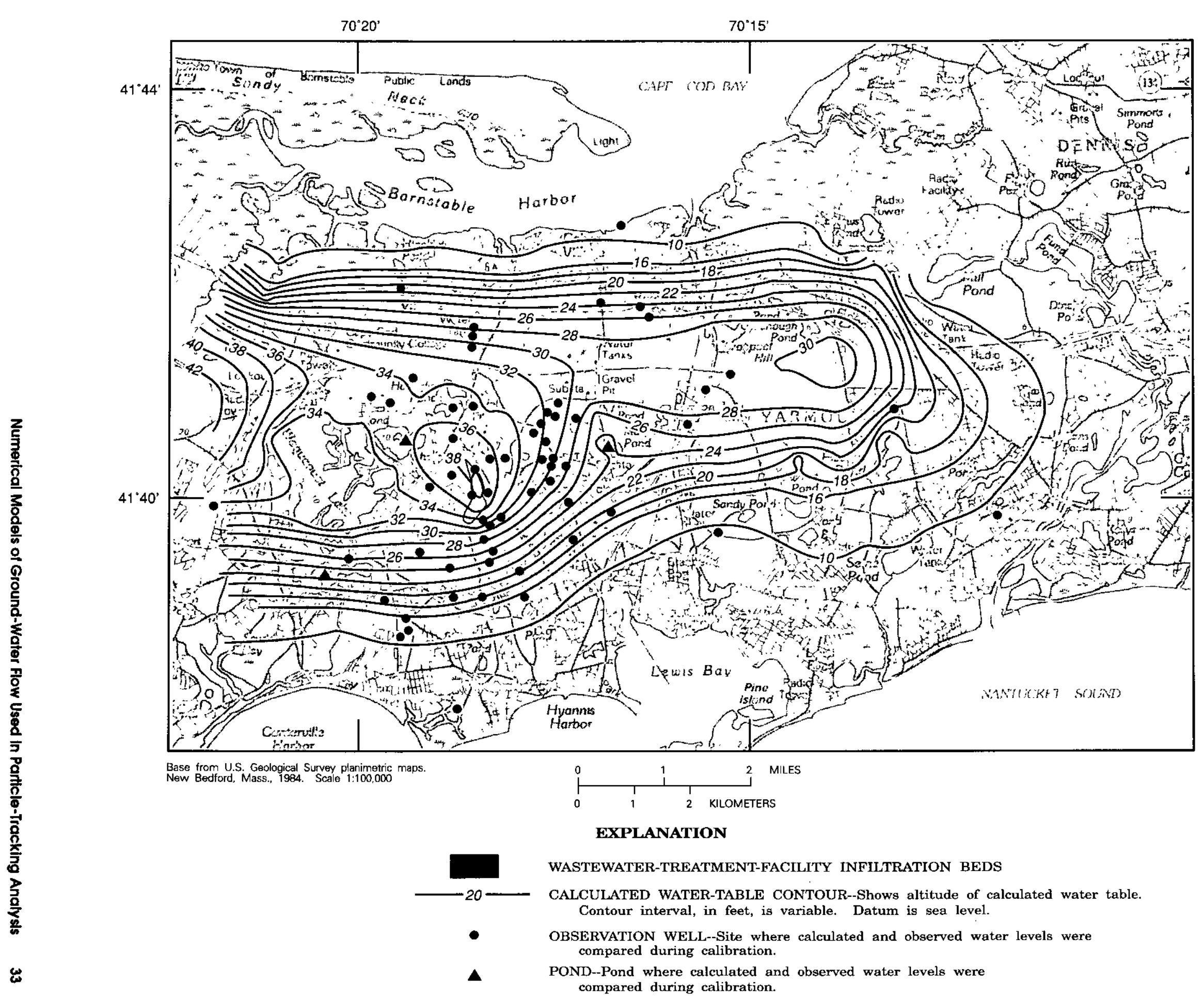

Figure 11. Calculated water-table configuration for the two-dimensional model of the complex flow system. 


\section{Procedure for Delineation of Contributing Areas}

The program MODPATH uses the heads and intercell flow rates (the flow rate at the face of each cell in the model) calculated by the flow model of McDonald and Harbaugh (1988) to determine particle pathlines and velocities. To determine particle velocities, MODPATH requires that the porosity of the material represented by each cell be specified. Uniform porosities of 0.39 for sand and gravel and 0.68 for silt and clay were specified for each cell of the models and are based on porosities reported for Cape Cod sediments presented earlier. MODPATH also requires specification of the altitude of the upper and lower boundaries of each cell (except the upper boundary of cells that simulate the water table). Because the bottom altitude of the fifth layer of the three-dimensional model of the simple flow system was not explicitly specified (because a transmissivity was used for that layer), a bottom altitude of $446 \mathrm{ft}$ below sea level was assigned to it in MODPATH. This altitude corresponds to the contact between glacial sediments and bedrock at test hole Eastham 45.

Starting locations of particles must be specified to initiate a particle-tracking analysis. Particles may be tracked either forward (from the water table to a pumped well) or backward (from a pumped well to the water table). Although both forward and backward particle tracking were tried during this investigation, forward tracking proved to be more useful for two reasons. First, complicated, discontinuous contributing areas were better defined by forward tracking than by backward tracking because it was often unclear whether areas located between particles tracked to the water table in backward-tracking analyses should be included in the contributing area to a well. In forward-tracking analyses, however, the contributing area of the well is defined by that area of the water table from which particles captured by the well originate. Second, forward tracking of particles proved useful in ensuring that each well captured a quantity of water sufficient to satisfy its specified pumping rate and, therefore, that the contributing area for each well was correct in size. Correct sizing was accomplished by first calculating the volume flow rate of each particle tracked to a well by multiplying the area of the water table represented by a particle (equal to the area of the cell in which the particle originates divided by the number of particles specified for each cell) by the recharge rate to the cell in which the particle originates; that is,

$$
Q p_{(x)}=\left[\begin{array}{ll}
A p & R
\end{array}\right]_{(x)},
$$

where

$Q p_{(x)}$ is the volume flow rate of particle $x$ $\left(\mathrm{L}^{3} / \mathrm{T}\right)$;

$A p \quad$ is the area of the water table represented by particle $x$, which is equal to the area of cell $i, j, k$ in which the particle originates divided by the number of particles specified for the cell $\left(\mathrm{L}^{2}\right)$; and

$R \quad$ is the total recharge rate to the top face of ccll $i, j, k$ in which particle $x$ originates $(L / T)$.

The volume flow rates of all particles captured by a well can then be summed to determine the total quantity of water captured by a well (referred to as the "calculated pumping rate" of the well); that is,

$$
Q^{\prime} w=\sum_{i=1}^{n} Q p_{(x)}
$$

where

$$
\begin{gathered}
Q^{\prime} w \quad \text { is the calculated pumping rate of the } \\
\text { well }\left(\mathrm{L}^{3} / \mathrm{T}\right) \text {; and } \\
n \quad \text { is the total number of particles } \\
\text { captured by the well. }
\end{gathered}
$$

Although equations 5 and 6 provide a useful means of ensuring that a well captures a quantity of water equal to its specified pumping rate, calculated and specified pumping rates may not be equal, for three reasons. First, water captured by the well may have originated from sources other than recharge at the water table, such as from specified-head or head-dependent flux boundaries that are not accounted for by equations 5 and 6 . Second, an insufficient number of particles may have been used in the delineation of the contributing area of the well. Finally, specified and calculated pumping rates may differ because of the presence of one or more weak internal boundary sinks within the contributing area of the well.

A weak internal boundary sink is a specified-flux or head-dependent flux boundary sink - such as a simulated pumped well, gaining stream, or drain-that docs not capture all flow crossing the six faces of the model cell in which the sink is located. In contrast, a strong internal boundary sink is one that captures all flow crossing the six faces of the model cell in which the sink 
is located. An example of a weak internal boundary sink is a simulated well that pumps only 67 percent of the water that flows into the cell in which the well is located. MODPATH does not remove particles from internal boundary sinks on the basis of the percentage of flow discharged by the weak sink. Consequently, there is no explicit way to determine whether a particle that enters a cell in which a weak sink is located should be discharged by the sink or pass through the cell (Pollock, 1989, p. 18).

There are two ways to address the problem of weak internal boundary sinks for the delineation of contributing areas. First, weak internal boundary sinks can be eliminated from a flow model by decreasing the vertical and (or) horizontal size of the model cells until all flow entering cells with internal boundary sinks is discharged by the sinks. It is often not practical, however, to reduce the size of grid cells to the point at which all weak internal boundary sinks are eliminated (Pollock, 1989, p. 20). Second, contributing areas can be delineated in two particle-tracking analyses that result in a maximum and minimum contributing area being defined for each well. In the first analysis, particles are stopped at weak internal boundary sinks, and, in the second, particles are allowed to pass through the weak sinks. Unless the well itself is a weak sink, the first analysis provides an estimate of the minimum size of the contributing area of each well and the second analysis provides an estimate of the maximum size of the contributing area of each well for the particular set of pumping, recharge, and hydrogeologic conditions simulated by the flow model. If the well itself is a weak sink, then the first analysis will provide the maximum contributing area to the well, and no contributing area will be defined for the well in the second analysis because all particles will pass through the weak sink cell in which the well is located. As is evident from the preceding discussion, the presence of weak internal boundary sinks, if not eliminated, can lead to ambiguities in the exact delineation of the contributing area of a well.

Of the two options for addressing the problem of weak internal boundary sinks, refining the model grid or completing two particle-tracking analyses, the latter option was chosen for this investigation. This was done because weak internal boundary sinks were not present in either the two- or three-dimensional models of the simple flow system and did not significantly affect contributing areas delineated for wells simulated by the three-dimensional model of the complex flow system. Though weak internal boundary sinks did affect the delineation of contributing areas delineated for wells simulated by the two-dimensional model of the complex flow system, the results of those particle-tracking analyses were used primarily to demonstrate the limitations of a two-dimensional model for delineation of contributing areas.

\section{Simple Flow System-Analysis of Contributing Areas to Two Hypothetical Wells}

Two hypothetical, large-capacity supply wells were simulated in the flow models developed for the simple flow system. Well A (which is located at test hole E45, fig. 2) is near the crest of a natural recharge mound where hydraulic gradients are low; well B is between this mound and discharge areas along the Atlantic coast, where gradients are steeper than those at the mound. These hypothetical wells were chosen for investigation because of their differing locations in the flow system and because they have been cited as possible locations for supply wclls for the town of Eastham. Contributing areas were delineated by use of nine particles, evenly spaced at the water table in each grid cell of the top layer of the model, and tracked in the forward direction to the wells. The distribution of nine particles per cell adequately defined the contributing area of each well for all simulations, as indicated by the fact that calculated pumping rates for the wells (from eqs. 5 and 6 ) were within 1 percent of specified pumping rates in the flow model. Conditions used in the simulations are summarized in table 10 .

\section{Delineation of Contributing Areas for a Pumping Rate of 0.5 Million Gallons Per Day Per Well}

Contributing areas can be difficult to delineate for conditions in which multiple wells are pumped simultaneously from an aquifer, because pumping at any one well can affect the flow of water to other wells. It is necessary, therefore, to simulate all pumped wells simultaneously in order to delineate the contributing area to any particular well accurately. When all wells are pumped simultaneously, contributing areas to individual wells do not overlap because it is impossible for a particle of water that originates at the water table to flow to more than one discharge point. When wells are pumped individually in separate simulations, however, contributing 
Table 10. Summary of hydrogeologic and model conditions for delineation of contributing areas of hypothetical wells $A$ and $B$ in the simple flow system

[--, not applicable to two-dimensional model $]$

Simulation number:

$\begin{array}{lllllllllllllllllllllllllll}1 & 2 a & 2 b & 2 c & 3 a & 3 b & 3 c & 4 a & 4 b & 4 c & 5 & 6 a & 6 b & 7 a & 7 b & 7 c & 7 d & 7 e & 7 f & 7 g & 7 h & 8 a & 8 b & 9\end{array}$

HYDROGEOLOGIC AND MODEL CONDITIONS

Model

$\begin{array}{llllllllllllllllllllllll}\text { Three dimensional ... } & \mathrm{x} & \mathrm{x} & \mathrm{x} & \mathrm{x} & \mathrm{x} & \mathrm{x} & \mathrm{x} & \mathrm{x} & \mathrm{x} & \mathrm{x} & \mathrm{x} & \mathrm{x} & \mathrm{x} & \mathrm{x} & \mathrm{x} & \mathrm{x} & \mathrm{x} & \mathrm{x} & \mathrm{x} & \mathrm{x} & \mathrm{x} & \mathrm{x} & \mathrm{x}\end{array}$

Two dimensional .....

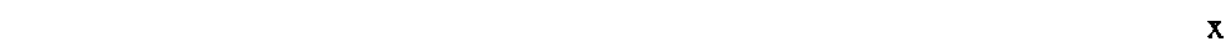

Layer of well screens

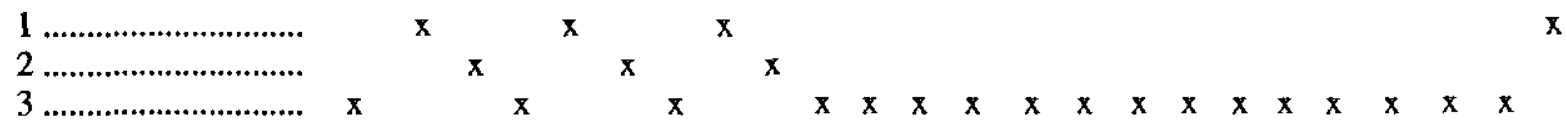

Well-discharge rates, in

million gallons per day

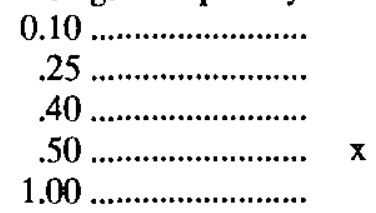

$\mathbf{X} \mathbf{X}$

$\times \mathbf{x}$

$\mathrm{x} \times \mathrm{x}$

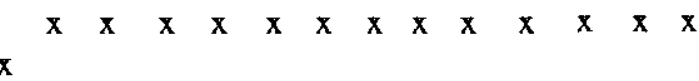

Ratio of horizontal to vertical hydraulic conductivity,

layers 1-3

Calibrated model

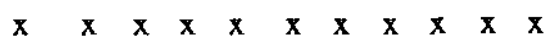

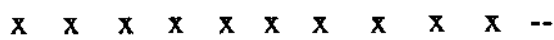

$0.1 \times$ calibrated model ....................

$0.01 \times$ calibrated model

Aquifer recharge

Calibrated model $0.8 \times$ calibrated model .....................

$1.2 \times$ calibrated

model...

Aquifer horizontal hydraulic conductivity

Calibrated model .....

$0.7 \times$ calibrated

model

X $\mathrm{X}$

$\begin{array}{lllll}\mathbf{X} & \mathrm{X} & \mathrm{X} & \mathrm{X} & \mathrm{X}\end{array}$

$1.3 \times$ calibrated model

$\mathbf{x}$

X

$\mathrm{x}$

X 
Table 10. Summary of hydrogeologic and model conditions for delineation of contributing areas of hypothetical wells $A$ and $B$ in the simple flow system--Continued

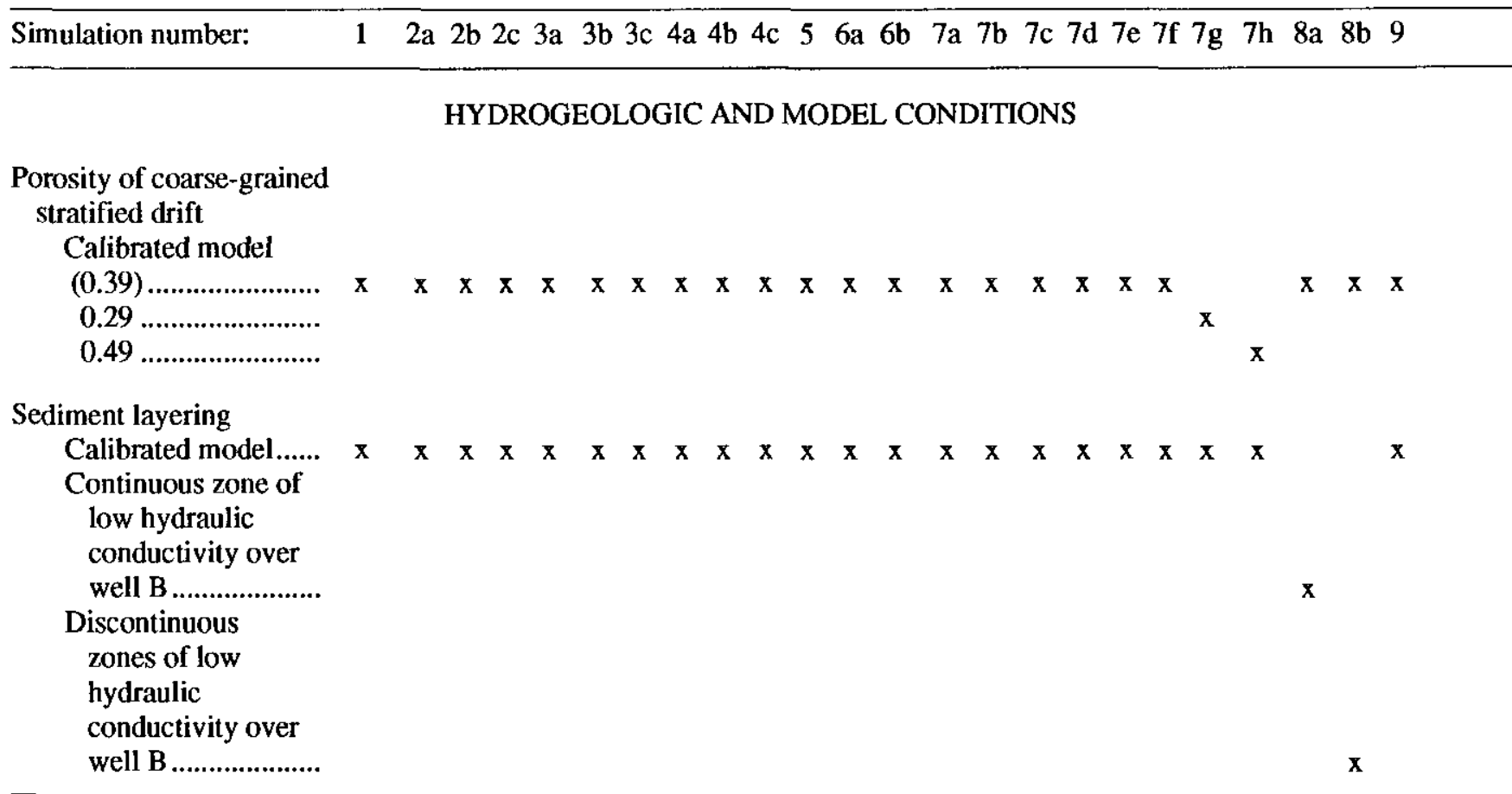

areas can overlap, and the total area delineated can be smaller than the area that would have resulted from wells being pumped simultaneously.

In the first simulation (the base simulation), each well was pumped at a rate of $0.5 \mathrm{Mgal} / \mathrm{d}$. The sizes of the contributing areas to wells $A$ and $B$ can be determined explicitly because recharge from precipitation is uniform over the contributing area of each well and because it is the only source of water to the wells. The contributing area for each well is $0.57 \mathrm{mi}^{2}$, which is equal to the discharge rate of each well, $0.5 \mathrm{Mgal} / \mathrm{d}$, divided by the recharge rate to the aquifer within the contributing area of each well, $18.3 \mathrm{in} / \mathrm{yr}$.

Contributing areas delineated for the wells indicate that the shape of the contributing area of each well depends on the location of the supply well in the flow system. The contributing area for well A (fig. 12), located near the crest of the recharge mound where head gradients are nearly flat, is oval; water is captured about equally from all areas around the well. The contributing area for well B, however, located between the crest of the recharge mound and the coastal discharge boundary of the aquifer, is elongate; water is captured primarily from areas that lie upgradient from the well. The bifurcation on the upgradient end of the contributing area for well $B$ results from the fact that particles of water originating at the water table between its tails follow threedimensional flow paths that end at the coastal boundary.

Pathlines of particles initiated at the water table along the row of the model in which well $B$ is located (row 55) show how particles move from the water table to discharge points at the well or specified-head cells downgradient from the well (fig.13). Because hydraulic gradients produced by the well are steeper near the well than in other parts of the aquifer, ground-water and particle velocities are also highest near the well, as indicated by particle pathlines after 5 and 10 years of travel (fig.13).

Lines of equal particle traveltime to each well for simulation 1 are shown in figure 12. Traveltime estimates commonly are used to define protection zones around supply wells and can be used, for example, to estimate the traveltime to supply wells of contaminants released to an aquifer by an accidental spill. They also provide a means of computing the percentage of the discharge from each well that has traveled to the well in a 


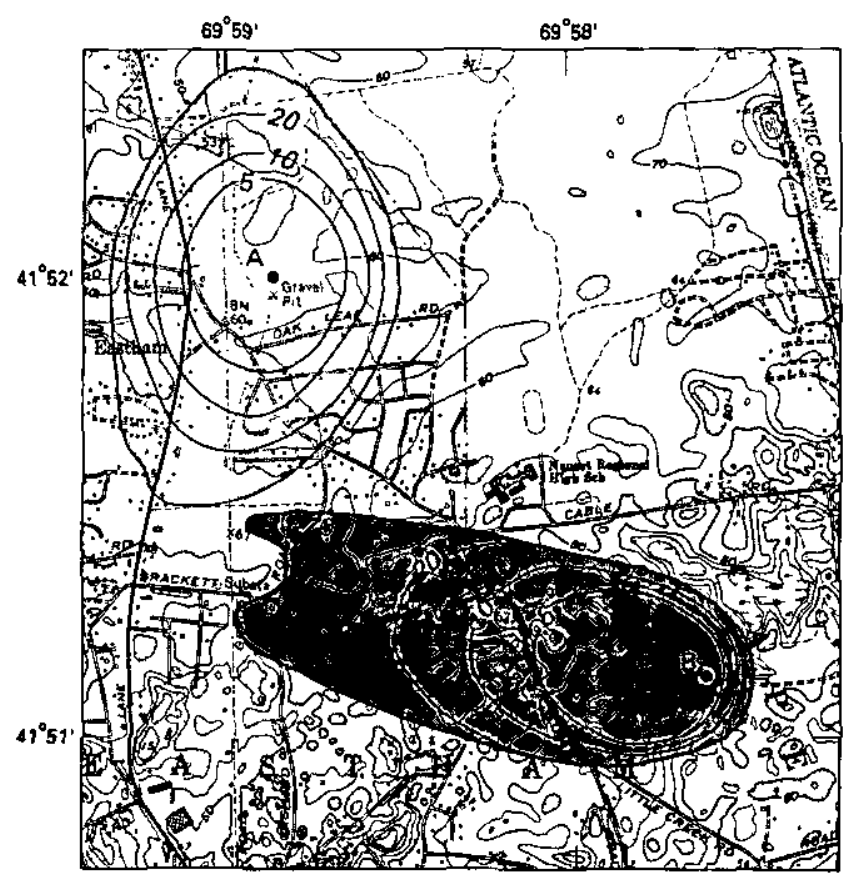

Base from U.S. Geologicai Survey

Orleans, Mass, , 1:25,000, 1974

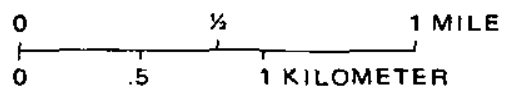

\section{EXPLANATION}

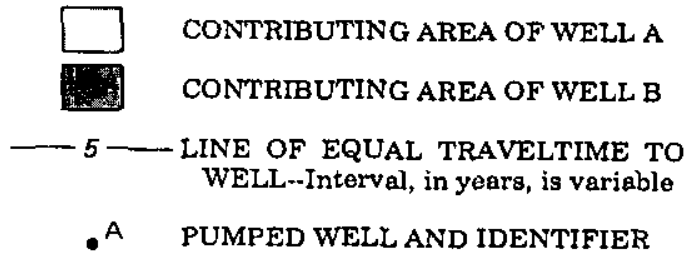

Figure 12. Contributing areas of and traveltimes to wells $A$ and $B$ for a pumping rate of 0.5 million gallons per day per well, determined by use of the three-dimensional model of the simple flow system.

specified pcriod of time. For example, table 11 indicates that, for simulation 1 , approximately 8.4 percent of the particles captured by well $\mathrm{A}$ and 6.8 percent of those captured by well B take less than 2 years to travel from their point of entry at the water table to the pumped wells. Table 11 also indicates that more than 25 percent of the water discharged from each well. takes longer than 20 years to travel to the well from the water table.

\section{Sensitivity of Contributing Areas to Selected Factors}

Hydrogeologic and well-design factors and vertical discretization of the model were varied in several simulations to evaluate the effect of these factors on the delineation of contributing areas of the two wells.
Penetration of Well Screens, Pumping Rates of Wells, and Ratlo of Horizontal to Vertical Hydraulic Conductivity

Public-supply wells in the glacial deposits of Cape Cod commonly are screened through only a small part of the vertical thickness of the aquifer, that is, the wells partially penetrate the aquifer. Partial penetration of well screens can affect the area from which water is captured by a supply well because the distribution of head near the well is, in part, a function of the depth from which water is withdrawn and the ratio of horizontal to vertical hydraulic conductivity of aquifer sediments near the well, in addition to the rate at which the well is pumped and location of the well in the flow system. Several simulations (simulations 2-6, table 10) were completed to assess the effect of partial penetration of well screens, pumping rate of the well, and ratio of horizontal to vertical hydraulic conductivity of aquifer scdiments to the delineation of contributing areas of the hypothetical wells. The results of the simulations are discussed simultaneously because of the interrelations among the threc factors to the delineation of contributing areas.

In simulations $2 \mathrm{a}$ through $2 \mathrm{c}$, each well was pumped at a rate of $0.1 \mathrm{Mgal} / \mathrm{d}$, and the model layer from which water was withdrawn was increased from layer 1 in simulation $2 \mathrm{a}$ to layer 3 in simulation 2c. Results of the three simulations (fig. 14) indicate that the vertical location of the well screen has an important effect on the delineation of the contributing area to well $\mathrm{B}$ at this low pumping rate. As is shown in figure 14 , the contributing area for well B does not surround the wellhead when the screened interval of the well is deeper than the top layer of the model (figs. $14 B$ and $14 C$ ). At this low pumping rate, drawdowns produced by the well when it is screened in laycrs 2 or 3 are too small to capture water recharging the aquifer in the immediate vicinity of the well. Because the well is midway bctwcen the upgradient and downgradient boundaries of the aquifer, as the well screcn is placed progressively deeper in the flow system the well captures water that has recharged the aquifer progressively farther upgradient from the well. The vertical location of the screened interval of well $\mathrm{A}$, however, has a negligible effect on the location and shape of the contributing area, and the contributing area surrounds the well for all three simulations. This results from the location of well A near the top of the recharge mound-there are no sources of water to the well beyond the surrounding recharge mound. Particle traveltimes (table 11 , simulations $2 \mathrm{a}-\mathrm{c}$ ) for these simulations indicate that increasing the depth of the screen 

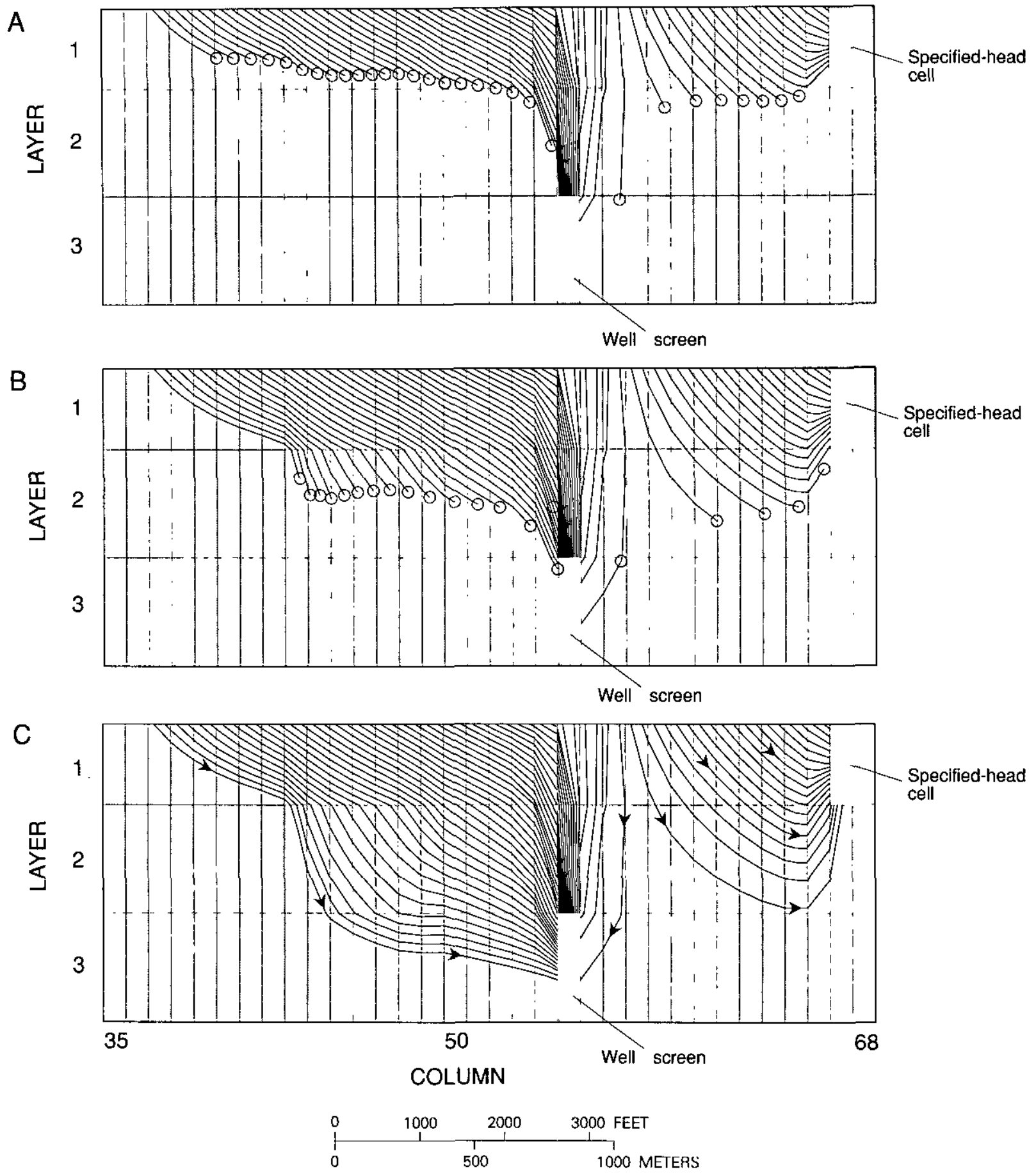

VERTICAL SCALE GREATLY EXAGGERATED

EXPLANATION

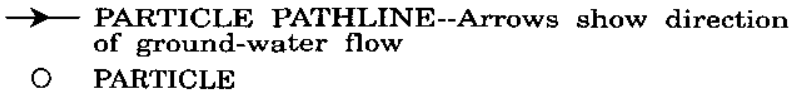

Figure 13. Particle pathlines in row 55 of the three-dimensional model of the simple flow system: $(A)$ affer 5 years of travel, (B) after 10 years of travel, and (C) for steady-state distribution of pathlines. 
Table 11. Traveltime of particles from the water table to hypothetical wells A and B in the simple flow system

$[\leq$, less than or equal to; Mgal/d, million gallons per day $]$

\begin{tabular}{llrrrr}
$\begin{array}{l}\text { Simulation number and } \\
\text { description (table 10) }\end{array}$ & Well & \multicolumn{4}{c}{ Traveltime } \\
\cline { 3 - 5 }
\end{tabular}

\section{PERCENTAGE OF WELL DISCHARGE}

1. Base simulation, pumping rate $0.5 \mathrm{Mgal} / \mathrm{d}$

$\begin{array}{lllll}\text { A } & 8.4 & 30.5 & 54.6 & 74.2 \\ \text { B } & 6.8 & 26.2 & 47.4 & 68.7\end{array}$

2. Pumping rate $0.1 \mathrm{Mgal} / \mathrm{d}$ :

a. Wells screened in

$\begin{array}{lllll}\text { A } & 20.0 & 40.0 & 61.9 & 76.3\end{array}$

layer 1

B $\quad 26.0$

50.6

75.7

93.3

b. Wells screened in

$\begin{array}{lllll}\text { A } & 5.4 & 22.2 & 48.2 & 73.0\end{array}$

layer 2

B $\quad 4 . \dot{4}$

21.7

48.9

76.7

c. Wells screened in layer 3

$\begin{array}{rrrrr}\text { A } & 0 & 10.6 & 39.3 & 68.9 \\ \text { B } & 0 & 2.4 & 21.6 & 52.0\end{array}$

5. Pumping rate $1.0 \mathrm{Mgal} / \mathrm{d}$, wells screened in layer 3

$\begin{array}{lllll}\text { A } & 14.4 & 36.1 & 57.0 & 75.1 \\ \text { B } & 12.4 & 30.8 & 50.5 & 70.4\end{array}$

6. Vertical hydraulic conductivity decreased, pumping rate $0.5 \mathrm{Mgal} / \mathrm{d}$ :
a. One order of magnitude
A 0
.7
30.3
20.2
66.8
B
0
0
54.8
b. Two orders of magnitude

$\begin{array}{ll}\text { A } & 0 \\ \text { B } & 0\end{array}$
0
0
22.6
0
0

7. Changes in model parameters, pumping rate $0.5 \mathrm{Mgal} / \mathrm{d}$ :
a. Hydraulic conductivity and recharge decreased
b. Hydraulic conductivity and recharge increased
g. Porosity decreased
A $\quad 6.0$
6.0
4.5
22.4
44.0
68.8
$\begin{array}{lr}\text { B } & 4.5 \\ \mathrm{~A} & 11.0\end{array}$
18.7
38.3
61.0
$\begin{array}{ll}\text { B } & 8.7\end{array}$
37.3
61.2
78.7
A $\quad 14.1$
32.2
54.0
72.8
B $\quad 11.9$
40.2
63.2
80.5
35.2
57.4
78.4
A $\quad 5.4$
23.8
46.5
68.1
B $\quad 3.9$
20.1
40.2
62.3

9. Two-dimensional model, pumping rate $0.5 \mathrm{Mgal} / \mathrm{d}$

$\begin{array}{lllll}\text { A } & 7.8 & 17.9 & 31.9 & 53.4 \\ \text { B } & 8.1 & 18.8 & 33.6 & 54.9\end{array}$



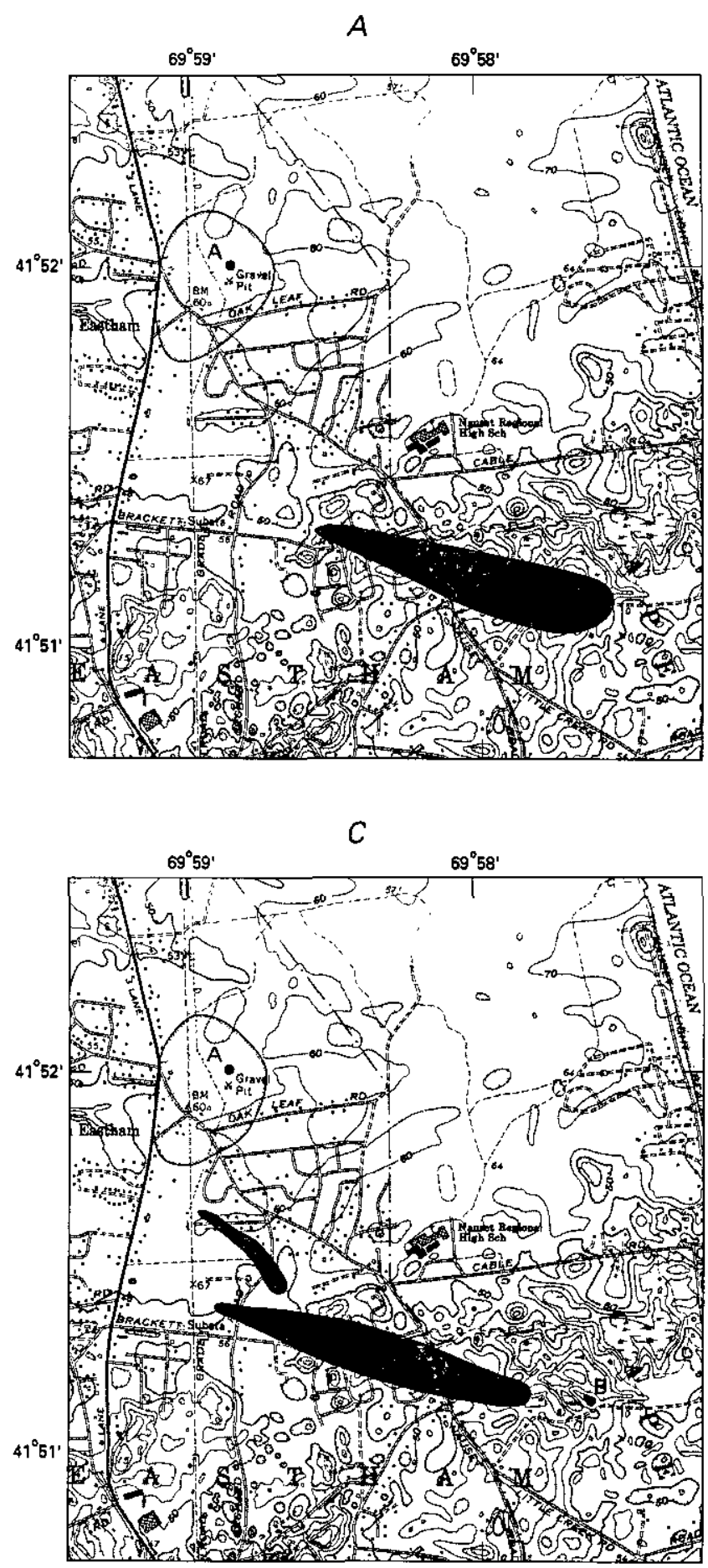

within the flow system increases the traveltimes of particles to the wells, because particle flow paths lengthen with increasing depth of the screen. A similar relation between particle traveltimes and the depth of the screened interval of a well has been reported by Reilly (1978).

When the pumping rate of each well was increased to $0.25 \mathrm{Mgal} / \mathrm{d}$ (simulations $3 \mathrm{a}-\mathrm{c}$ ) and $0.40 \mathrm{Mgal} / \mathrm{d}$
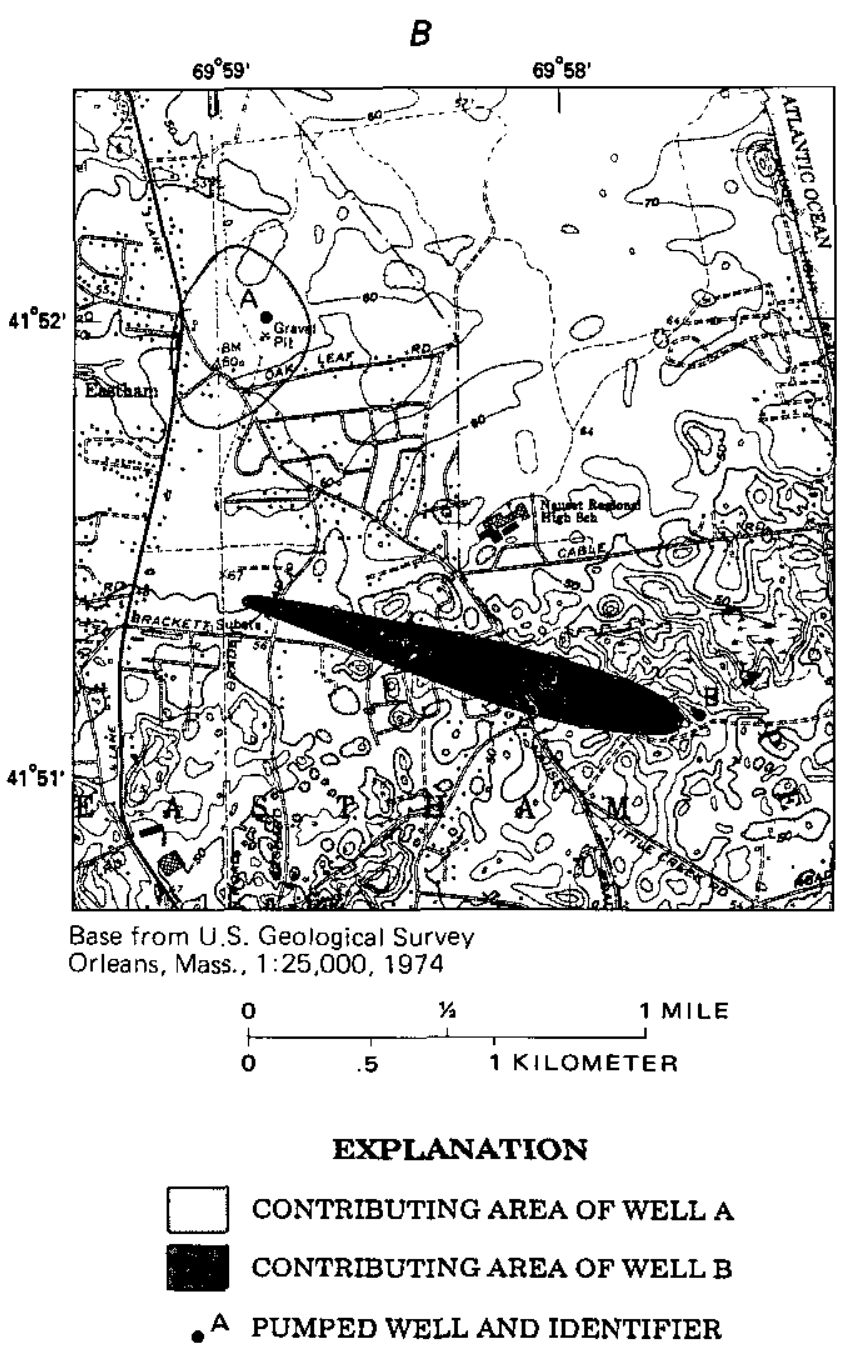

Figure 14. Contributing areas of wells $A$ and $B$ for well screens located in $(A)$ layer $1,(B)$ layer 2 , and (C) layer 3 of of the three-dimensional model of the simple flow system, at a pumping rate of 0.1 million gallons per day per well.

(simulations 4a-c), the size of the contributing area of each well increased also; however, at the higher pumping rate, the contributing areas surrounded both wells regardless of the vertical location of the well screen in the model. Contributing areas overlay the wells for these higher pumping rates because the drawdowns produced by the wells were large enough to cause water to flow from the overlying water table to the lower layers of the model. As the pumping rate of each 
well was increased from $0.1 \mathrm{Mgal} / \mathrm{d}$ to $1.0 \mathrm{Mgal} / \mathrm{d}$, particle velocities increased also because of increasingly steeper gradients produced by the increasing pumping rates. When each well was pumped at a rate of $1.0 \mathrm{Mgal} / \mathrm{d}, 36.1$ percent of the discharge from well $\mathrm{A}$ and 30.8 percent of the discharge from well B took less than 5 years to travel from the water table to each well, whereas at a pumping rate of $0.1 \mathrm{Mgal} / \mathrm{d}$ (and well screens were placed in layer 3 ), only 10.6 percent of the discharge from well A and only 2.4 percent of the discharge from well B took less than 5 years to travel from the water table to each well screen.

Two model simulations were completed to determine the effect of increases in the ratio of horizontal to vertical hydraulic conductivity on the delineation of contributing areas to hypothetical wells A and B (simulations 6a and 6b). The vertical hydraulic conductivities (and, therefore, vertical conductance in the model) of the top three layers were reduced first by one order of magnitude (simulation 6a) and then by two orders of magnitude (simulation $6 \mathrm{~b}$ ); each well was pumped at the rate of $0.5 \mathrm{Mgal} / \mathrm{d}$. Model results indicate that contributing areas delineated for well $\mathrm{B}$ are greatly affected by the increase in the ratio of horizontal to vertical hydraulic conductivity of the sediments (figs. 15 and $16 B$ ). When the vertical hydraulic conductivity is decreased, particle pathlines are deflected toward the horizontal because of the increased resistance to flow in the vertical direction (fig.16B), and the contributing area to well B is forced farther upgradient in the flow system than it is for the calibrated model of the natural system. It should also be noted that the contributing area to the well does not surround the well for the decreased values of vertical hydraulic conductivity (figs. 15 and $16 B$ ). The contributing area to well $\mathrm{A}$ is less affected by the reduction in vertical hydraulic conductivity than is well B because no sources of water to the well are upgradient from the surrounding watertable mound. Increases in the ratio of horizontal to vertical hydraulic conductivity greatly affected particle traveltimes for these two simulations (table 11, simulations $6 \mathrm{a}$ and $6 \mathrm{~b})$. Only in simulation $6 \mathrm{a}$ does any water

Figure 15. Contributing areas of wells $A$ and $B$ from simulation in which the vertical conductance of layers 1 through 3 of the three-dimensional model of the simple flow system is reduced by $(A)$ one order of magnitude and (B) two orders of magnitude.
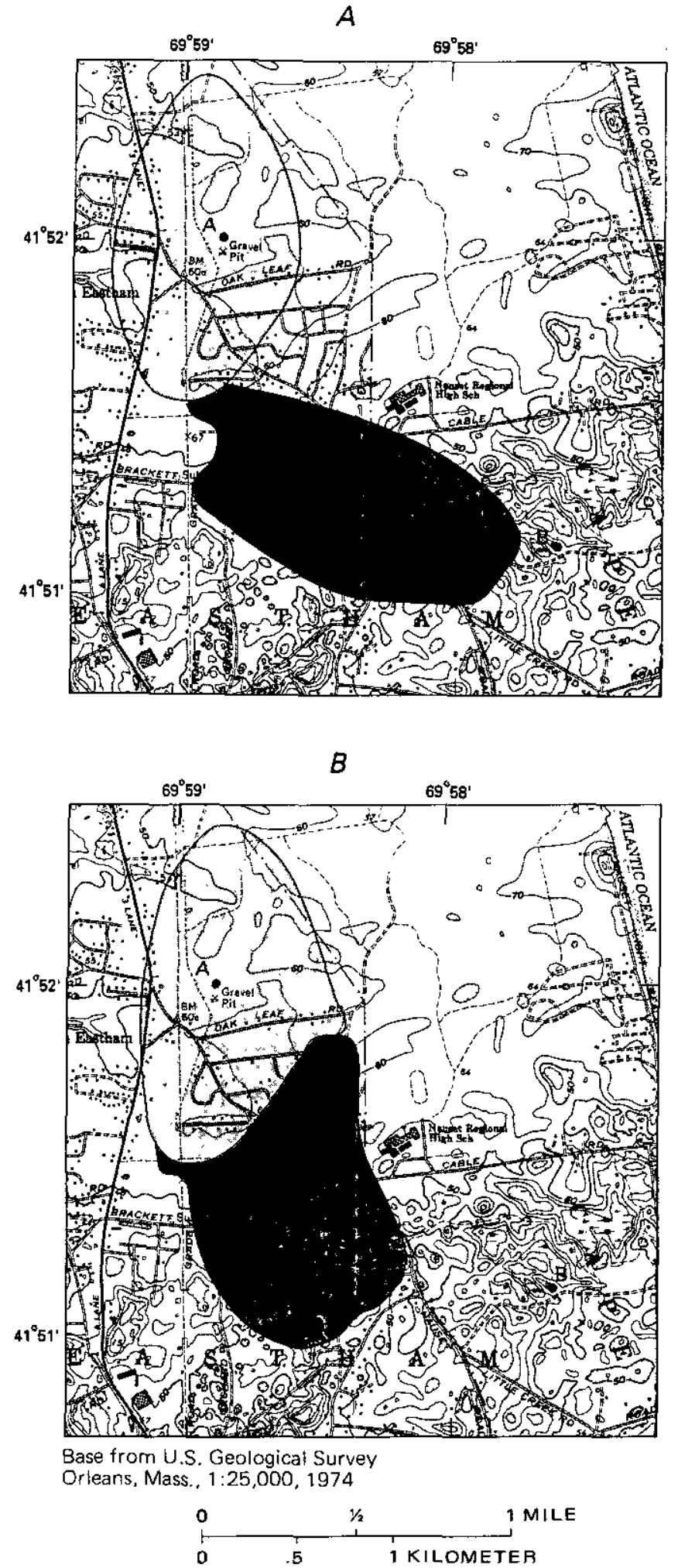

EXPLANATION

CONTRIBUTING AREA OF WELI A

CONTRIBUTING AREA OF WELL B

- A PUMPED WELL AND IDENTIFIER 



VERTICAL SCALE GREATLY EXAGGERATED

\section{EXPLANATION}

ZONE OF LOW HYDRAULIC CONDUCTIVITY

PARTICLE PATHLINE

Figure 16. Particle pathlines in row 55 of the three-dimensional model of the simple flow system from $(A)$ simulation of the natural system, $(B)$ simulation in which the vertical conductance of the top two layers is reduced by two orders of magnitude, and $(C)$ simulation of a lens of low hydraulic conductivity near well $B$. 
take less than 5 years to reach well A or B, because of the strong resistance to downward flow caused by the large ratios of horizontal to vertical hydraulic conductivity.

\section{Paramefer Uncertainty: Horlzontal Hydraullic Conductivity, Recharge, and Porosity}

The values of hydraulic conductivity, areal recharge, and porosity specified for a ground-water-flow model and particle-tracking analysis are estimates of the actual aquifer properties. Results of the sensitivity analysis for the three-dimensional model of the simple flow system (fig. 7) indicated that there is a range over which simultaneous changes in the hydraulic conductivity of the top layer of the model and the recharge rate to the aquifer will have little effect on the mean error between observed and calculated heads. One way to evaluate the effect of uncertainty in the estimates of these parameters on the delineation of contributing areas is to complete a series of simulations in which the valucs of each parameter are varied over what is considered to be the range of uncertainty for each parameter. Six simulations (simulations $7 \mathrm{a}-\mathrm{f}$ ) were done in which horizontal hydraulic conductivity of the top layer of the model and recharge values were changed first simultaneously and then individually to assess the importance of each of these two parameters to the delineation of contributing areas of these wells. In simulation $7 \mathrm{a}$, horizontal hydraulic conductivities of the top layer of the model were decreased by 30 percent of the calibrated-model values and recharge was simultaneously decreased by 20 percent of the calibrated-model values. In simulation $7 \mathrm{~b}$, horizontal hydraulic conductivities were increased by 30 percent of the calibrated-model values and recharge was simultaneously increased by 20 percent of the calibrated-model values. Values used for these parameters in these two simulations correspond to points in figure 7 in which the mean error between observed and simulated heads is equal to or less than $1.0 \mathrm{ft}$. Four subsequent simulations then were done (simulations $7 \mathrm{c}-\mathrm{f}$ ), in which only one of the two parameters was varied while the second was held at the calibrated values (table 10). Each well was pumped at a rate of $0.5 \mathrm{Mgal} / \mathrm{d}$ in all six simulations.

Results of the first two simulations (7a and $7 b)$ in which values of both parameters were changed simultaneously are shown in figure 17 . The size of each contributing area was increased from the base simulation of 0.57 to $0.72 \mathrm{mi}^{2}$ when recharge was reduced to 80 percent of its calibrated value (fig. 17 A) and decreased to $0.49 \mathrm{mi}^{2}$ when recharge was increased to 120 percent of its calibrated value (fig. $17 B$ ) . The 30 percent increase and decrease in the hydraulic conductivity of the top layer of the model (simulations $7 \mathrm{e}-\mathrm{f}$ ) did not noticeably affect the location or shape of contributing areas delineated for either well when recharge was held at the calibrated value. Therefore, the range in size and location of the contributing areas to the wells for these six simulations are determined by simulations $7 \mathrm{a}$ and $7 \mathrm{~b}$ (fig.17); contributing areas delineated for the remaining four simulations $(7 \mathrm{c}-\mathrm{f})$ fall within these maximum (fig.17A) and minimum (fig.17B) contributing areas.

Although hydraulic conductivity is less important than the rate of recharge in determining the size of the contributing areas delineated for the two wells in this simulation, Morrissey (1989) showed that hydraulic conductivity affected the size of contributing areas delincated for a well pumping near a river in a hypothetical river-valley aquifer of New England. As the hydraulic conductivity of the aquifer was increased, the volume of induced infiltration from the river decreased because of increased preferential flow of water to the well from the stratified drift.

Values specified for hydraulic conductivity and recharge also affect particle traveltimes. When these two parameters are decreased, as in simulation $7 \mathrm{a}$, traveltimes to the wells gencrally increase (table 11), whereas when the two parameters are increased, traveltimes to the wells generally decrease (table 11). Within the range of hydraulic conductivity and recharge used in these simulations, however, the two parameters had a smaller influence on particle traveltimes than did variations in the location of the screened interval and pumping rates of each well and the ratio of horizontal to vertical hydraulic conductivity.

Uncertainty in the value of porosity specified for each model cell can also affect particle traveltimes, but not the actual location or shape of contributing area delineated for each well or the path that individual particles take from the water table to each well. Two simulations were made in which the porosity of sand and gravel was first decreased from 0.39 to 0.29 (simulation $7 \mathrm{~g}$ ) and then increased from 0.39 to 0.49 

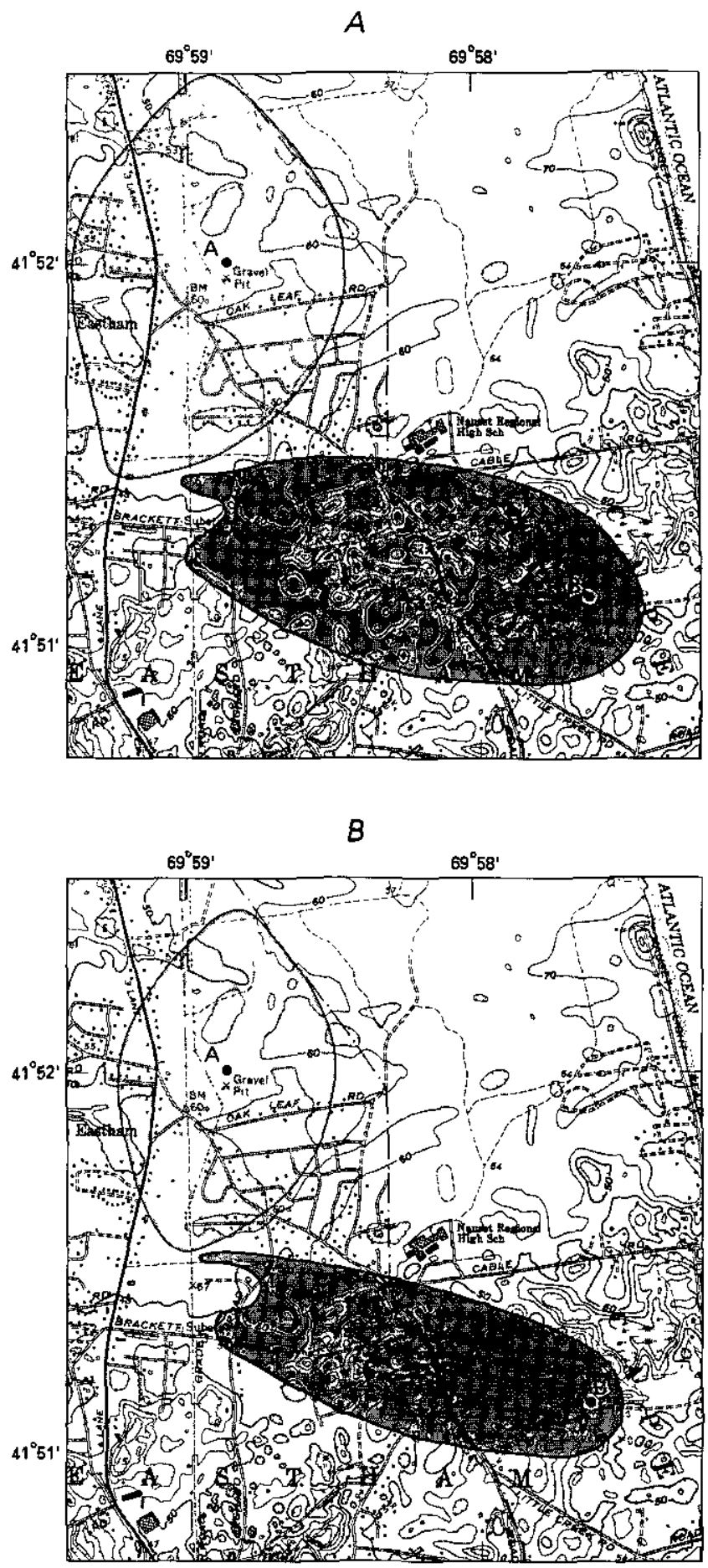

Base from U.S. Geological Survey

Orleans, Mass., 1:25,000, 1974

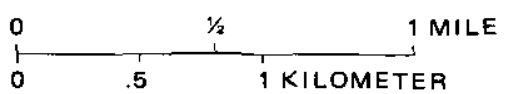

EXPLANATION

CONTRIBUTING AREA OF WELL A CONTRIBUTING AREA OF WELL B

- A PUMPED WELL AND IDENTIFIER (simulation $7 \mathrm{~h}$ ). These changes represent a 25 -percent decrease and increase, respectively, in the porosity used for these sediments in the base simulation and correspond approximately to ranges of porosity reported for fine to coarse sand (Morris and Johnston, 1967, p. D17D21; Davis and DeWeist, 1966, p. 375). Results of the simulation indicate that, as would be expected, particle traveltimes increase with decreased porosity (simulation $7 \mathrm{~g}$ ) and decrease with increased porosity (simulation $7 \mathrm{~h}$ ). The range in traveltimes for the two simulations, however, are again not as significant as the ranges determined when the vertical location of well screens, the pumping rates of the wells, and the ratios of horizontal to vertical hydraulic conductivity were varied.

\section{Sediment Heterogeneity}

Vertical and horizontal heterogeneities in aquifer properties can have a significant effect on ground-water flow, and, therefore, would be expected to have an effect on the location and shape of the contributing area of a supply well. Two simulations were done to investigate the effect of discrete changes in the distribution of coarse- and fine-grained sediments near well $B$ to the delineation of contributing areas by introducing continuous and discontinuous lenses of sediments of low hydraulic conductivity, representative of silt and clay, near well B (fig. 18). Although these two simulations cannot cover the range of heterogeneity that might exist in an aquifer, they illustrate the influence that heterogeneity can have on the flow of water to supply wells. The lenses of low hydraulic conductivity were placed in Iayer 2 of the model. The screened interval of each well was placed in layer 3 , and each well was pumped at a rate of $0.5 \mathrm{Mgal} / \mathrm{d}$. In the first simulation (simulation $8 \mathrm{a}$ ), a $0.42-\mathrm{mi}^{2}$ lens of low hydraulic

Figure 17. Contributing areas of wells $A$ and $B$ in the simple flow system for $(A)$ recharge rate equal to 80 percent of the calibrated-model value and horizontal hydraulic conductivity of layer 1 of the three-dimensional model equal to 70 percent of the calibrated-model value and $(B)$ recharge rate equal to 120 percent of the calibrated-model value and horizontal hydraulic conductivity of layer 1 of the three-dimensional model equal to 130 percent of the calibrated-model value. 

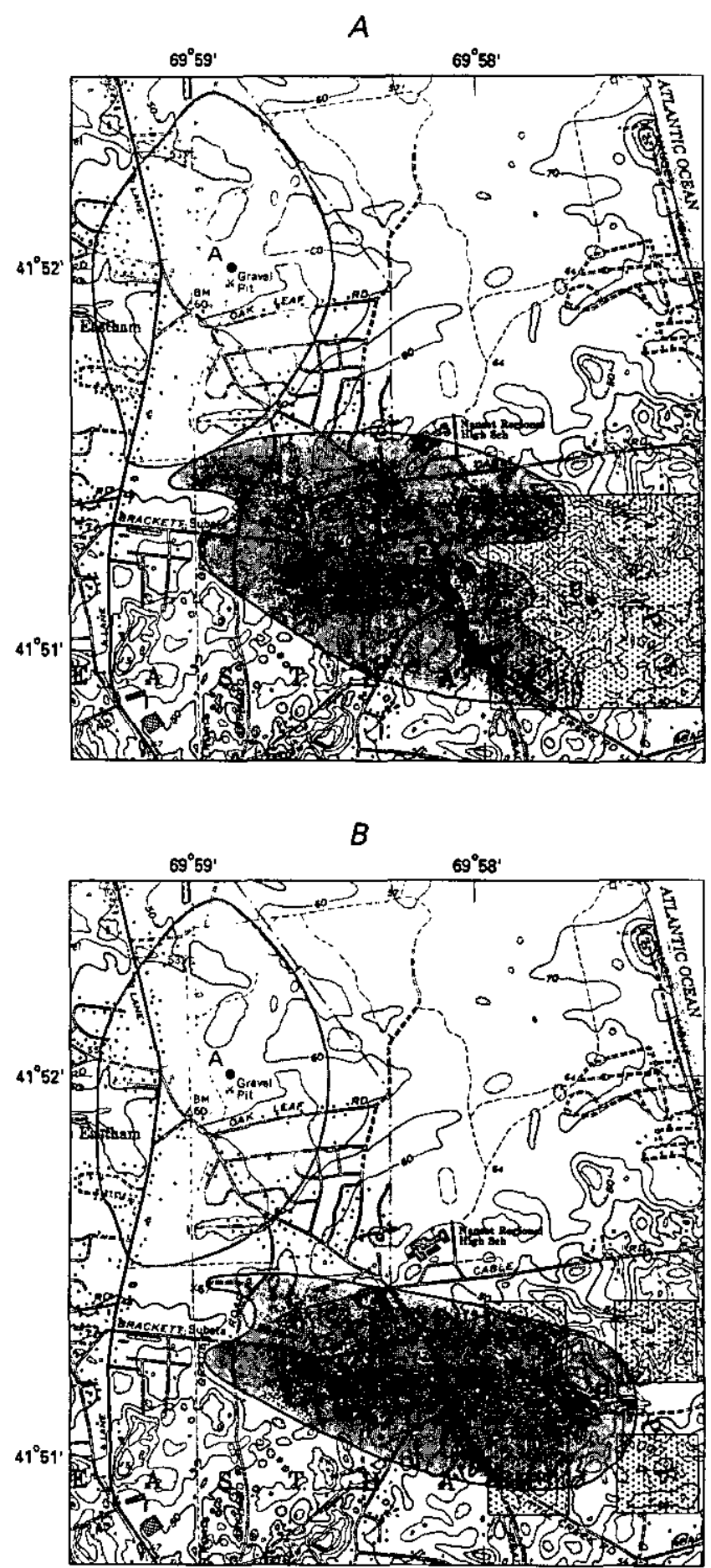

Base from U.S. Geological Survey

Orleans, Mass., $1: 25,000,1974$

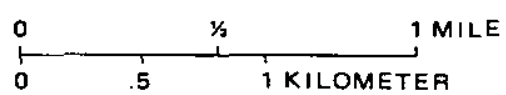

EXPLANATION

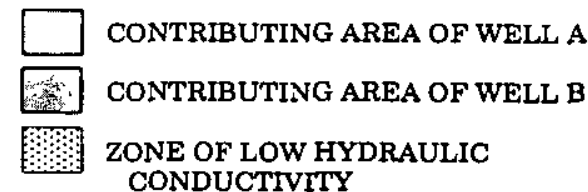

- A PUMPED WELL AND IDENTIFIER conductivity was placed above well $B$. In the second simulation (simulation $8 \mathrm{~b}$ ), four discontinuous lenses of low hydraulic conductivity, each $0.06 \mathrm{mi}^{2}$ in extent, were placed near well $B$.

Results of the first simulation (fig. 18A) show that the location of the contributing area to well $B$ is greatly changed from that of the initial simulation (fig. 12) by the introduction of a continuous lens of silt and clay, which diminishes the rate of vertical movement of water near the well (fig. $16 C$ ). The surface area that contributes water to well B does not overlie the well (figs. $16 C$ and 18A). All water captured by the well is from areas upgradient from the well and primarily from beyond the upgradient limit of the zone of low hydraulic conductivity. Recharge to the aquifer in the vicinity of well B discharges to the natural boundary of the aquifer (the Atlantic Ocean) downgradient from the well. In figure $16 C$, several pathlines converge and fall steeply on the downgradient end of the lens of silt and clay, forcing a substantial volume of water to the deeper layers of this part of the modeled aquifer. In the second simulation, discontinuous lenses of silt and clay overlie the screened interval of the well (fig. 18B). Results of the second simulation differ significantly from those resulting from a continuous lens (the first simulation). In this second simulation, windows of highly conductive aquifer overlie the screened interval, and contributing areas are nearly identical to those delineated for the wells for the base simulation (simulation 1a) in which no silt and clay lenses were near the wellhead (fig. 12).

The results of these two simulations show the importance of accurately defining the lithology of an aquifer near a well in order to accurately delineate its contributing area. Undetected lenses of high hydraulic conductivity within lenses of low hydraulic conductivity may provide unexpected conduits through which contaminants may pass to underlying aquifers. The results of these simulations also show the utility of particle tracking for the delineation of contributing areas to wells pumping from heterogeneous systems in

Figure 18. Contributing areas of wells $A$ and $B$ from simulation of $(A)$ a continuous zone and $(B)$ discontinuous zones of low hydraulic conductivity near well B, determined by use of the threedimensional model of the simple flow system. 
which lenses of low hydraulic conductivity greatly affect the flow of water to wells and complicate delineation.

\section{Vertical Discretization of Flow Model}

The preceding contributing areas for hypothetical wells A and B were delineated by simulation of flow in three dimensions; vertical components of flow were simulated in the process. In many thin, stratified-drift aquifers, however, ground-water flow is predominantly horizontal, except near areas of recharge and discharge. The importance of these vertical components of groundwater flow in the simple system was determined by comparison of contributing areas delineated by use of the three-dimensional model with those delineated by use of the two-dimensional model, in which each well was pumped at $0.5 \mathrm{Mgal} / \mathrm{d}$. Because the two-dimensional model is a single-layer model, the well screens extend over the full thickness of the model.

Contributing areas delineated for each well by use of the two-dimensional model were very similar in location and extent to those delineated by use of the threedimensional model (fig. 19) because of the uniformity of aquifer materials, near-ideal boundary conditions, and high pumping rates at the wells. Contributing areas delineated by use of the two models were also similar for pumping rates of $0.25 \mathrm{Mgal} / \mathrm{d}$. These results indicate that the delineation of contributing areas to wells in this flow system is not greatly improved by use of the three-dimensional model; therefore, the use of a threedimensional model for simulation of three-dimensional flow in this system does not seem to be warranted for these pumping conditions. Nevertheless, the preceding discussions of the effect of partial penetration of well screens, low pumping rates of wells, ratios of horizontal to vertical hydraulic conductivity larger than the stratified drift, and the presence and continuity of discrete lenses of low hydraulic conductivity have indicated conditions in which vertical-flow components can have a significant effect on the delineation of contributing areas of wells in even this simple flow system.

Figure 19. Contributing areas of wells $A$ and $B$ for $a$ pumping rate of 0.5 million gallons per day per well by use of $(A)$ the three-dimensional model and $(B)$ the two-dimensional model of the simple flow system.
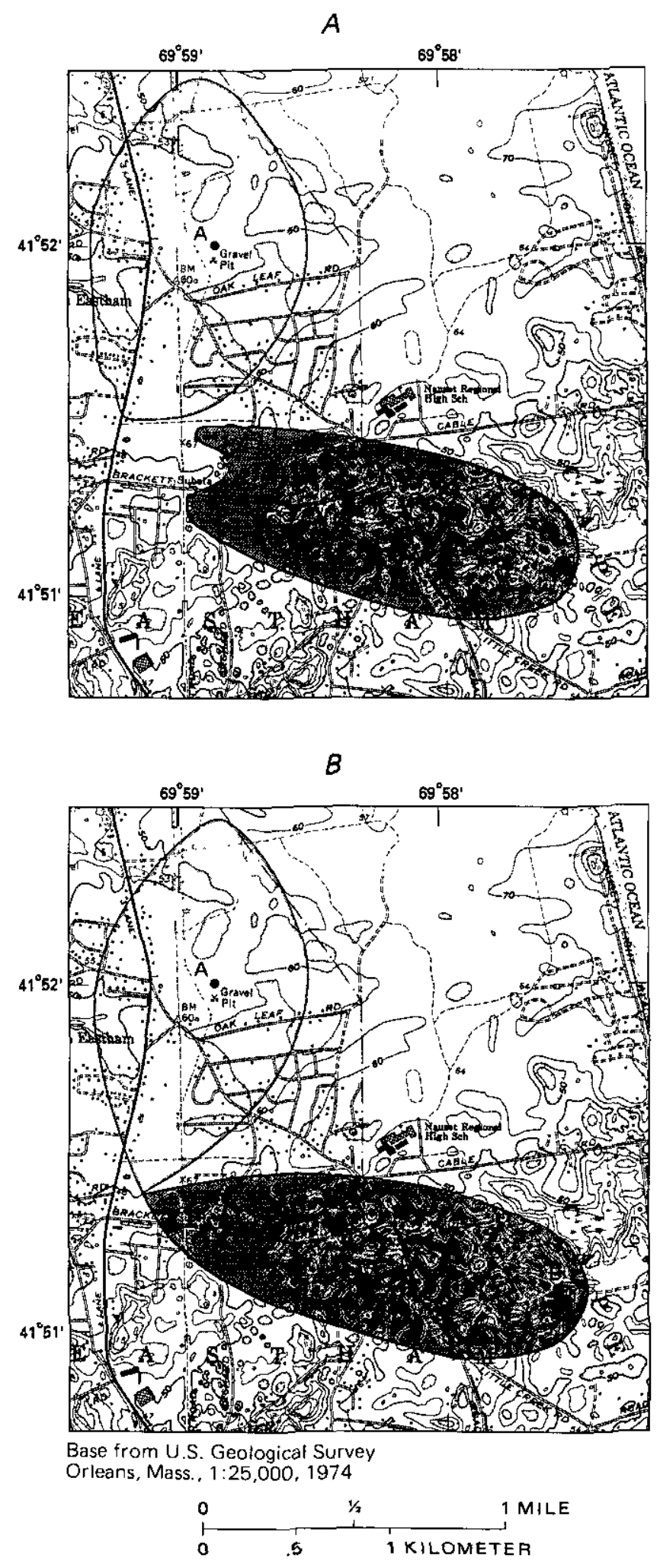

EXPLANATION

CONTRIBUTING AREA OF WELI A

CONTRIBUTING AREA OF WELL B

- A PUMPED WELL AND IDENTIFIER 


\section{Complex Flow System-Analysis of Contributing Areas to Existing Wells}

Thirty-four public-supply wells in Barnstable and Yarmouth were simulated in the flow models developed for the complex flow system (table 12), though contributing areas were delineated for only 15 of these wells. These 15 wells, all in Bamstable, were chosen to demonstrate the delineation of contributing areas because they have variable screen locations and pumping rates; are near ponds, streams, and areas of wastewater return flow; and are in different geologic parts of the aquifer. The analysis of contributing areas of these 15 wells is divided into three parts: (1) delineation of contributing areas of the 15 wells by use of the 1987 average daily pumping rates (the base simulation); (2) identification of the source of water for each well for the 1987 average daily pumping rates; and (3) a sensitivity analysis measuring the effect of changes in selected model variables and discretization on the delineation of contributing areas and source of water to the wells.

Contributing areas were delineated by use of an evenly spaced distribution of four particles per cell that started at the water table. Two tests were used to determine if contributing areas were affected by weak sinks: mass-balance verification by comparison of specified pumping rates with pumping rates calculated by use of equations 5 and 6; and visual verification by overlaying the two contributing areas delineated for each well by use of the two options for stopping particles at weak internal boundary sinks.

\section{Delineation of Contributing Areas for 1987 Average Daily Pumping Rates}

In the base simulation, each well was pumped at its 1987 average daily pumping rate. These pumping rates were the largest average daily pumping rates during 198087. Discharge from well $\mathrm{CO}-8$ was divided
Table 12. Average daily pumping rates in 1987 for wells simulated in the models of the complex flow system

[USGS, U.S. Geological Survey; B, Barnstable; Y, Yarmouth]

\begin{tabular}{|c|c|c|c|c|c|}
\hline \multicolumn{3}{|c|}{ Model node } & \multirow{2}{*}{$\begin{array}{l}\text { Local } \\
\text { well } \\
\text { number }\end{array}$} & \multirow{2}{*}{$\begin{array}{c}\text { USGS } \\
\text { well } \\
\text { number }\end{array}$} & \multirow{2}{*}{$\begin{array}{l}\text { Pumping } \\
\text { rate } \\
\text { (cubic fee } \\
\text { per day) }\end{array}$} \\
\hline Layer & Row & Column & & & \\
\hline 1 & 61 & 77 & BWC-MD1 & В 387 & 12,000 \\
\hline 2 & 60 & 79 & BWC-MD2 & В 383 & 36,100 \\
\hline 1 & 58 & 77 & BWC-MD3 & В 403 & 5,300 \\
\hline 1 & 55 & 77 & BWC-MD4 & B 402 & 36,100 \\
\hline 3 & 67 & 80 & BWC-AIR & В 300 & 30,800 \\
\hline 5 & 110 & 48 & BWC-HY & В 229 & 50,800 \\
\hline 5 & 108 & 49 & BWC-SI & B 384 & 94,900 \\
\hline 4 & 81 & 85 & BWC-ME1 & В 377 & 24,100 \\
\hline 4 & 81 & 87 & BWC-ME2 ${ }^{1}$ & В 385 & 104,300 \\
\hline 1 & 52 & 53 & SG & В 497 & 25,400 \\
\hline 2 & 39 & 51 & BFD-1 & B 228 & 2,700 \\
\hline 3 & 55 & 68 & BFD-2 & B 370 & 24,100 \\
\hline 4 & 48 & 38 & BFD-3 & B 416 & 38,800 \\
\hline 4 & 100 & 33 & $\mathrm{CO}-7$ & В 226 & 17,400 \\
\hline 2 & 103 & 33 & $\mathrm{CO}-8^{2}$ & B 227 & 4,700 \\
\hline 3 & 103 & 33 & $\mathrm{CO}-8^{2}$ & B 227 & 4,700 \\
\hline 2 & 102 & 33 & $\mathrm{CO}-11$ & В 368 & 13,400 \\
\hline 2 & 50 & 104 & YWC-1 & Y 41 & 9,400 \\
\hline 1 & 49 & 106 & YWC-2 & Y 42 & 13,400 \\
\hline 1 & 47 & 107 & YWC-3 & Y 43 & 16,000 \\
\hline 5 & 68 & 137 & YWC-4 & Y 64 & 18,700 \\
\hline 5 & 68 & 137 & YWC-5 & Y 65 & 20,100 \\
\hline 4 & 48 & 146 & YWC-6,7,8 & Y 53 & 40,100 \\
\hline 4 & 45 & 146 & YWC-9 & Y 54 & 32,100 \\
\hline 3 & 58 & 130 & YWC-10 & Y 61 & 16,000 \\
\hline 2 & 62 & 129 & YWC-11 & Y 63 & 14,700 \\
\hline 3 & 65 & 117 & YWC-13 & Y 58 & 25,400 \\
\hline 3 & 73 & 111 & YWC-14 & Y 128 & 18,700 \\
\hline 5 & 35 & 142 & YWC-15 & Y 126 & 26,700 \\
\hline 5 & 36 & 141 & YWC-16 & Y 127 & 26,700 \\
\hline 5 & 74 & 113 & YWC-17 & Y 195 & 33,400 \\
\hline 4 & 70 & 117 & YWC-18 & Y 193 & 24,100 \\
\hline 4 & 69 & 118 & YWC-19 & Y 194 & 25,400 \\
\hline 3 & 57 & 104 & YWC-20 & Y 166 & 18,700 \\
\hline 3 & 27 & 125 & YWC-MN & Y 103 & 50,800 \\
\hline
\end{tabular}

${ }^{1}$ Well includes discharge from both BWC-ME2 and BWCME3.

${ }^{2}$ Screened interval of well extends over two layers of the model. 
evenly between layers 2 and 3 of the model because the midpoint of its well screen lies at about the contact of the two model layers.

Pumping rates calculated for the wells by use of equations 5 and 6 are given with specified pumping rates in table 13. Calculated pumping rates for the 15 wells range from 96.3 to 109.7 percent of specified pumping rates when particles are stopped at weak internal boundary sinks, indicating that calculated pumping rates are within 10 percent of specified pumping rates for all wells. When particles were allowed to pass through weak sinks, however, calculated pumping rates range from 0 to 122.4 percent of specified pumping rates. As discussed in the "Procedure for Delineation of Contributing Areas", there are three possible reasons why calculated and specified pumping rates may not be equal: (1) sources of water other than recharge to the water table; (2) the presence of weak internal boundary sinks; and (3) an insufficient number of particles used to delineate the contributing areas. The only possible source of water to the wells in addition to recharge to the water table is from the head-dependent flux boundary cells at Wequaquet Lake. To determine if these boundary cells are a source of water to any of the wells, each of the weak-sink options was used to track particles from the lake to each of the 15 wells. Results of the simulations indicate that less than 1 percent of the water captured by well BWC-HY and none of the water captured by the other 14 wells consists of lake water. Water from the lake, therefore, cannot account for the bulk of the discrepancies between calculated and specified pumping rates.

Differences between the calculated pumping rates based on the two weak-sink options for the last seven wells in table 13 (BWC-MD2, BWC-MD3, BWCME1, BWC-ME2, CO-7, CO-8, and CO-11) indicate that weak internal boundary sinks affect the delineation of their contributing areas. Wells BWC-MD3, BWC$\mathrm{ME} 1, \mathrm{CO}-7, \mathrm{CO}-8$, and $\mathrm{CO}-11$ are themselves weak

Table 13. Specified pumping rates and pumping rates calculated by use of the three-dimensional model for selected wells in the complex flow system

[Pumping rates are shown in cubic feet per day]

\begin{tabular}{|c|c|c|c|c|c|}
\hline \multirow[b]{2}{*}{$\begin{array}{l}\text { Local } \\
\text { well } \\
\text { number }\end{array}$} & \multirow[b]{2}{*}{$\begin{array}{l}\text { Specified } \\
\text { pumping } \\
\text { rate }\end{array}$} & \multicolumn{2}{|c|}{ Particles passed through weak sinks } & \multicolumn{2}{|c|}{ Particles stopped at weak sinks } \\
\hline & & $\begin{array}{l}\text { Calculated } \\
\text { pumping rate }\end{array}$ & $\begin{array}{l}\text { Percentage of } \\
\text { specified } \\
\text { pumping rate }\end{array}$ & $\begin{array}{c}\text { Calculated } \\
\text { pumping rate }\end{array}$ & $\begin{array}{l}\text { Percentage of } \\
\text { specified } \\
\text { pumping rate }\end{array}$ \\
\hline BWC-HY & 50,800 & 50,200 & 98.8 & 50,200 & 98.8 \\
\hline BWC-SI & 94,900 & 95,300 & 100.4 & 95,300 & 100.4 \\
\hline BFD-1 & 2,700 & 2,600 & 96.3 & 2,600 & 96.3 \\
\hline BFD-2 & 24,100 & 23,800 & 98.8 & 23,800 & 98.8 \\
\hline BFD-3 & 38,800 & 39,200 & 101.0 & 39,200 & 101.0 \\
\hline BWC-AIR & 30,800 & 30,300 & 98.4 & 30,300 & 98.4 \\
\hline BWC-MD1 & 12,000 & 12,300 & 102.5 & 12,300 & 102.5 \\
\hline BWC-MD4 & 36,100 & 35,900 & 99.4 & 35,900 & 99.4 \\
\hline BWC-MD2 & 36,100 & 41,700 & 115.5 & 36,000 & 99.7 \\
\hline BWC-MD3 & 5,300 & 0 & 0 & 5,700 & 107.5 \\
\hline BWC-ME1 & 24,100 & 0 & 0 & 24,200 & 100.4 \\
\hline BWC-ME2 ${ }^{1}$ & 104,300 & 127,700 & 122.4 & 103,600 & 99.3 \\
\hline $\mathrm{CO}-7$ & 17.400 & 0 & 0 & 18.100 & 1040 \\
\hline $\mathrm{CO}-8^{2}$ & 9,400 & 0 & 0 & 9,100 & 96.8 \\
\hline $\mathrm{CO}-11$ & 13,400 & 0 & 0 & 14,700 & 109.7 \\
\hline
\end{tabular}

${ }^{1}$ Well includes discharge from both BWC-ME2 and BWC-ME3.

${ }^{2}$ Screened interval of well extends over two layers of the model. 
boundary sinks, as indicated by calculated pumping rates of zero for the wells when particles are permitted to pass through weak-sink cells. The first eight wells listed in table 13 (BWC-HY, BWC-SI, BFD-1, BFD-2, BFD-3, BWC-AIR, BWC-MD1, and BWC-MD4) are unaffected by weak sinks, as is evident from the fact that calculated discharge rates for these eight wells are equal for both weak-sink options. An insufficient number of particles per cell is presumed to account for the discrepancy between calculated and specified discharge rates for these eight wells unaffected by weak internal boundary sinks, and the lack of particles may also account for some of the discrepancies between calculated and specified discharge rates for the seven wells affected by weak internal boundary sinks.

The preceding discussion of calculated and specified pumping rates indicates that stopping particles at weak internal boundary sinks provides a more accurate delineation of contributing areas for wells in this modeled flow system than does letting particles pass through weak sinks. This is because few weak internal boundary sinks are upgradient from the 15 wells and because the grid cells used to simulate wells were small enough that nearly all the water entering cells in which weak-sink wells were located was discharged by the wells.

Contributing areas shown for the 15 public-supply wells in figure 20 include the contributing areas of ponds that are sources of water to the wells. The contributing areas shown in figure 20 are the maximum contributing area delineated for each well by use of the two particle-tracking weak-sink options. Contributing areas of ponds that contribute pond throughflow to well discharge are included because water particles that reach a pond were assumed to be well mixed within the pond; therefore, it is not possible to determine those parts of the contributing area of a pond that actually supply water to a particular well. It was, however, possible to determine the quantity of water captured by each well that had passed through model cells that represent ponds ("pond cells") by use of equations 5 and 6 . This was done by determining which particles captured by a well had passed through pond cclls. As shown in table 14, several of the supply wells capture pond throughflow, and pond throughflow accounts for up to 73 percent of well discharge (by use of the option to stop particles at weak intemal boundary sinks).

Contributing areas delineated for the wells range from 0.02 to $1.13 \mathrm{mi}^{2}$ when particles are stopped at weak sinks (table 15). The values shown in table 15 include the areas that contribute water directly to each well and arcas that contribute water to ponds that are sources of pond throughflow to the wells. Consequently, there is no direct correlation between the pumping rate of each well and the size of the contributing area of each well, as there was for wells in the simple flow system. Even if ponds do not contribute throughflow, however, pumping rates and contributing area sizes are not directly correlated because recharge rates are spatially variable near the wells.

Also shown in figure 20 are the contributing areas previously delineated for the wells by use of an analytical model described by Horsley (1983). Contributing areas delineated by use of particle tracking are generally smaller than those delineated by use of the analytical model because the recharge rates were higher and pumping rates were lower for the particle-tracking model than for the analytical model. Some of the contributing areas delineated by particle tracking - such as those for wells BWC-HY, BWC-SI, and BFD-3-do not conform to the simple ellipsoidal shapes that are typically delineated for pumped wells by use of twodimensional analytical and numerical modeling techniques, and a few of the contributing areas include discontinuous areas of the water table. Contributing areas do not overlie wells BFD-1, CO-8, CO-11, or $\mathrm{BWC}-\mathrm{HY}$. It is likely that the contributing area to BFD1 does not overlie the well because of the low pumping rate of the well $(0.02 \mathrm{Mgal} / \mathrm{d})$, because its screcned interval is about 40 to $50 \mathrm{ft}$ below the water table, and because it is in the moraine, where the ratio of horizontal to vertical hydraulic conductivity is higher than in the stratified drift to the south.

Contributing areas to five wells (BWC-HY, BWCSI, $\mathrm{CO}-7, \mathrm{CO}-8$, and $\mathrm{CO}-11$ ) are shown in figures 21 and 22 at a larger scale than in figure 20 to illustrate the complexity of contributing areas delineated for individual wells in this flow system. A combination of hydrogeologic factors and well-design characteristics are assumed to affect the contributing areas delineated for each well. For example, contributing areas delineated for wells BWC-HY and BWC-SI (fig. 21) are affected, in part, by the location of their screened intervals beneath a thin, discontinuous lens of silt and clay, as well as by their location midway between the watertable mound east of Wequaquet Lake and a discharge boundary of the aquifer at Nantucket Sound. The 
A

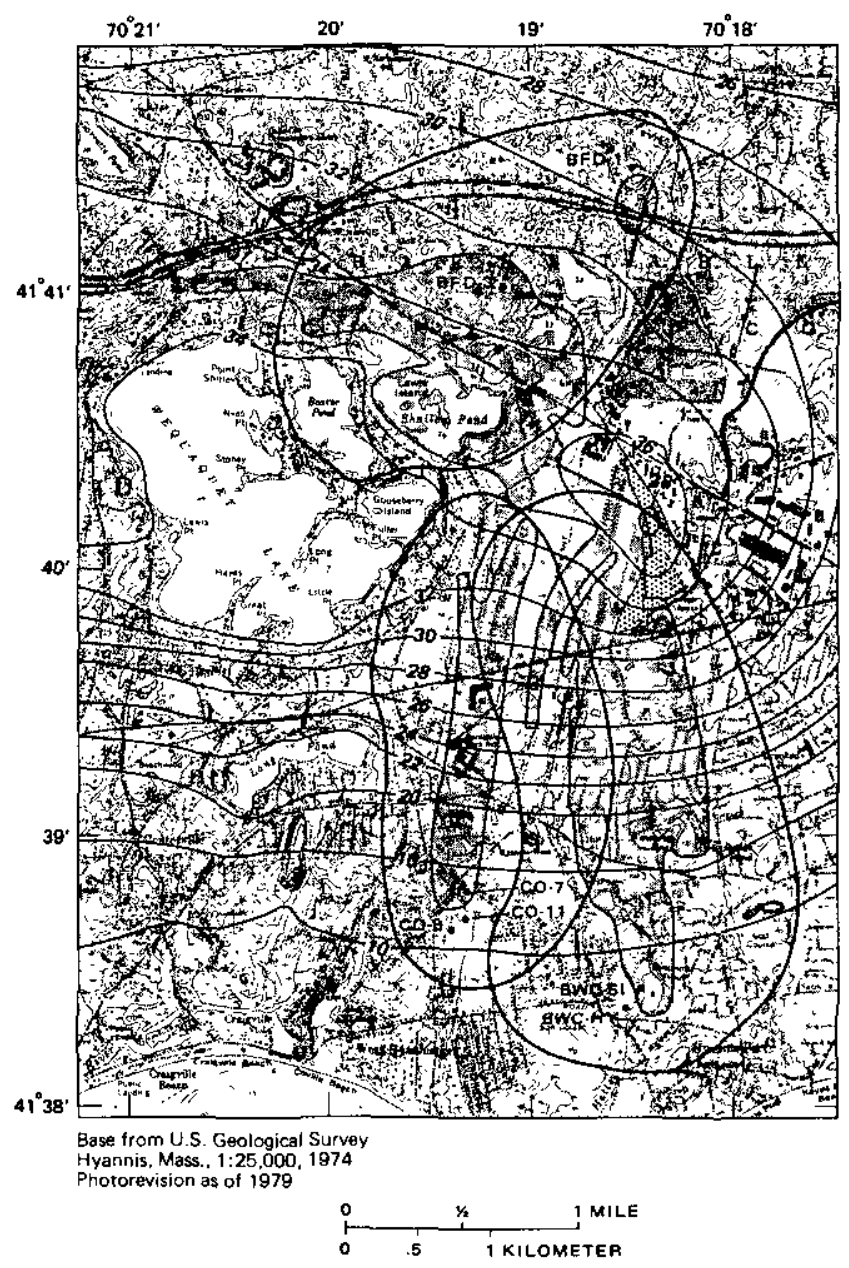

B

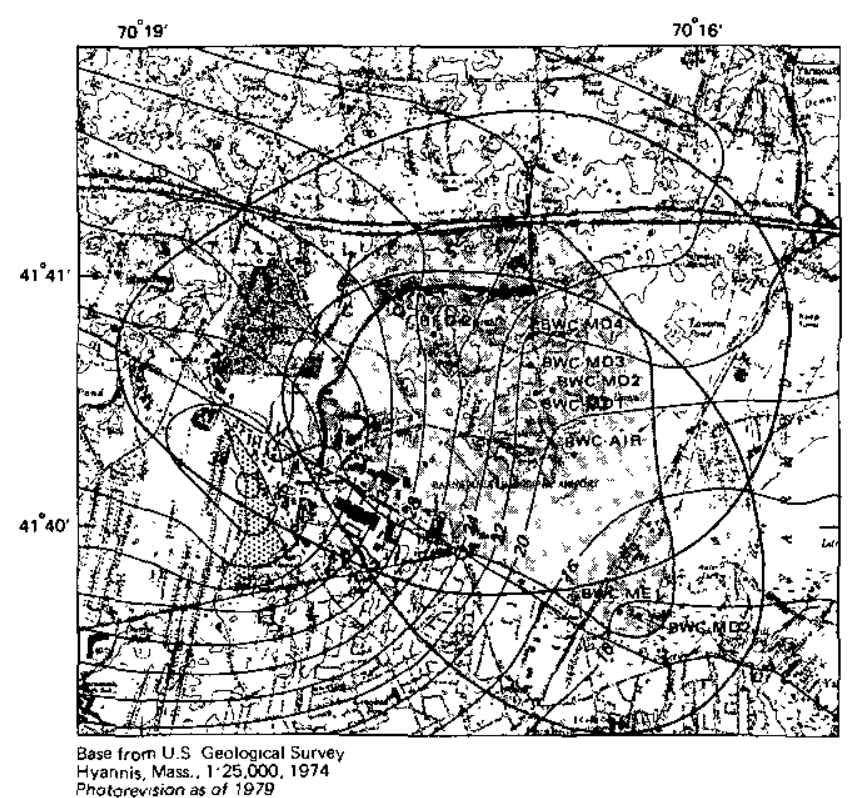

EXPLANATION

WASTEWATER-TREATMENT-FACILITY INFILTRATION BEDS CONTRIBUTING AREA OF PUBLIC-SUPPLY WELLS-FO 1987 average daily pumping ratea, determined by means of the

BOUNDARY OF CONTRIBUTING AREA OF PUBLIC-SUPPLY WELLS-Determined by means of an analytical model

-24- CALCULATED WATER.TABLE CONTOUR. Shown altitude of calculated water table. Contour interval, in feet, is variable.
Datum is aea level

BFO-2 PUBLIC-SUPPLY WELL AND LOCAL WELL NUMBER

Figure 20. Contributing areas of 15 public-supply wells in the complex flow system. A. Western part of modeled area, B. Central part of modeled area

location and shape of the contributing areas for the wells result, in concept, from processes similar to those that affected the contributing area for well $\mathrm{B}$ in the simple flow system when a hypothetical lens of silt and clay was introduced immediately over the screened interval of that well (fig. 18A). The lens of silt and clay diminishes the rate of vertical movement of water near the wells, a conclusion that is further supported by pathlines near the wells that show little flow of water through the lens. Both wells also capture parts of their discharges from nearby ponds.

Contributing areas delineated for wells $\mathrm{CO}-7, \mathrm{CO}-8$, and $\mathrm{CO}-11$ (fig. 22) provide examples of how partial penetration of well screens, low pumping rates, multiple pumped wells, and the location of a well within a flow system can affect the contributing area of a well. Each of the three wells is pumped at a very low rate $(0.07-0.13 \mathrm{Mgal} / \mathrm{d})$, are screened from 30 to $50 \mathrm{ft}$ below the water table, and are midway between the water-table mound east of Wequaquet Lake and a discharge area of the aquifer at Nantucket Sound. The aquifer in the area of the wells consists of sand and gravel, and no lenses of low hydraulic conductivity overlie the well screens. None of the contributing areas delineated for the wells overlie the wellheads; these conditions are similar to those for well B in the simple flow system when that well was pumped at a rate of only $0.1 \mathrm{Mgal} / \mathrm{d}$ and was screened from about 18 to $75 \mathrm{ft}$ below the water table (fig. 14). The contributing area of well $\mathrm{CO}-7$, which is the furthest upgradient well in the three-well cluster, lies at the core of the three contributing areas, whereas the 
Table 14. Amount of pond throughflow to selected wells in the complex flow system, as a percentage of well pumping rates

\begin{tabular}{lc}
\hline $\begin{array}{c}\text { Local well } \\
\text { number }\end{array}$ & $\begin{array}{c}\text { Percentage of } \\
\text { pumping rate }\end{array}$ \\
\hline BWC-HY & 21.6 \\
BWC-SI & 52.3 \\
BFD-1 & 0 \\
BFD-2 & 3.1 \\
BFD-3 & 6.1 \\
BWC-AIR & 73.0 \\
BWC-MD1 & 13.1 \\
BWC-MD4 & 26.1 \\
BWC-MD2 & 52.9 \\
BWC-MD3 & 66.8 \\
BWC-ME1 & 22.0 \\
BWC-ME2 & 5.7 \\
CO-7 & 0 \\
CO-8 & 0 \\
CO-11 & 0 \\
\hline
\end{tabular}

Table 15. Size of contributing areas of selected wells in the complex flow system, determined by use of the three-dimensional model

[ $\mathrm{mi}^{2}$, square mile]

\begin{tabular}{lccc}
\hline $\begin{array}{c}\text { Local } \\
\text { well } \\
\text { number }\end{array}$ & $\begin{array}{c}\text { Size of the } \\
\text { contributing } \\
\text { area to the well } \\
\left(\mathrm{mi}^{2}\right)\end{array}$ & $\begin{array}{c}\text { Local } \\
\text { well } \\
\text { number }\end{array}$ & $\begin{array}{c}\text { Size of the } \\
\text { contributing } \\
\text { area to the well } \\
\left(\mathrm{mi}^{2}\right)\end{array}$ \\
\hline BWC-HY & 0.71 & BWC-ME1 & 0.33 \\
BWC-SI & .69 & BWC-ME2 & 1.13 \\
BFD-1 & .02 & CO-7 & .11 \\
BFD-2 & .26 & CO-8 & .06 \\
BFD-3 & .59 & CO-11 & .09 \\
& & & \\
BWC-AIR & .37 & & \\
BWC-MD1 & .18 & & \\
BWC-MD4 & .39 & & \\
BWC-MD2 & .44 & & \\
BWC-MD3 & .09 & & \\
\hline
\end{tabular}

contributing area of well CO-8, which is the furthest downgradient well in the three-well cluster, lies on the periphery of the contributing areas.

\section{Source of Water to the Wells}

In the preceding section, it was noted that recharge is the only source of water to 14 of the supply wells and constitutes more than 99 percent of the water pumped by the 15th well (BWC-HY). Although ponds contribute water to the discharge of several of the wells, pond throughflow is not an ultimate source of water. Two sources of recharge were simulated in the flow models of the complex flow system-precipitation and wastewater return flow. Particles tracked in these flow models therefore may consist of both precipitation and wastewater recharge components. This is shown by substituting the recharge rate to each cell $(R)$ in equation 5 by the sum of the recharge rate from precipitation $(R p r e c)$ and that from wastewater return flow (Rwaste) to each cell:

$$
\begin{aligned}
& Q p_{(x)}=(\text { Ap }[\text { Rprec }+ \text { Rwaste }])_{(x)} \\
& =[\text { ApRprec }]_{(x)}+[\text { ApR R waste }]_{(x)},
\end{aligned}
$$

where

$Q p_{(x)}$ is the volume flow rate of particle $x\left(\mathrm{~L}^{3} / \mathrm{T}\right)$,

$A p$ is the area of the water table represented by particle $x\left(\mathrm{~L}^{2}\right)$,

Rprec is the precipitation component of recharge to the cell in which particle $x$ originates $(\mathrm{L} / \mathrm{T})$,

$R$ waste is the wastewater component of recharge to the cell in which particle $x$ originates $(\mathrm{L} / \mathrm{T})$,

[Ap Rprec $_{(x)}$ is the precipitation-recharge component of the volume flow rate of particle $x\left(\mathrm{~L}^{3} / \mathrm{T}\right)$, and

[Ap Rwaste $_{(x)}$ is the wastewater-recharge component of the volume flow rate of particle $x\left(\mathrm{~L}^{3} / \mathrm{T}\right)$.

The quantity of water from each source captured by the 15 wells was then determined by the substitution of equation 8 into equation 6 :

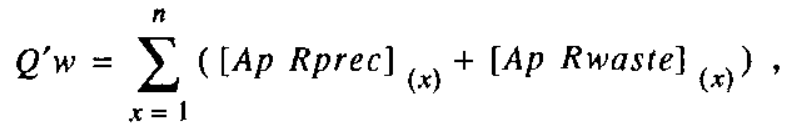

where

$Q^{\prime} w$ is the calculated pumping rate of the well $\left(\mathrm{L}^{3} / \mathrm{T}\right)$; and

$n \quad$ is the total number of particles captured by the well. 


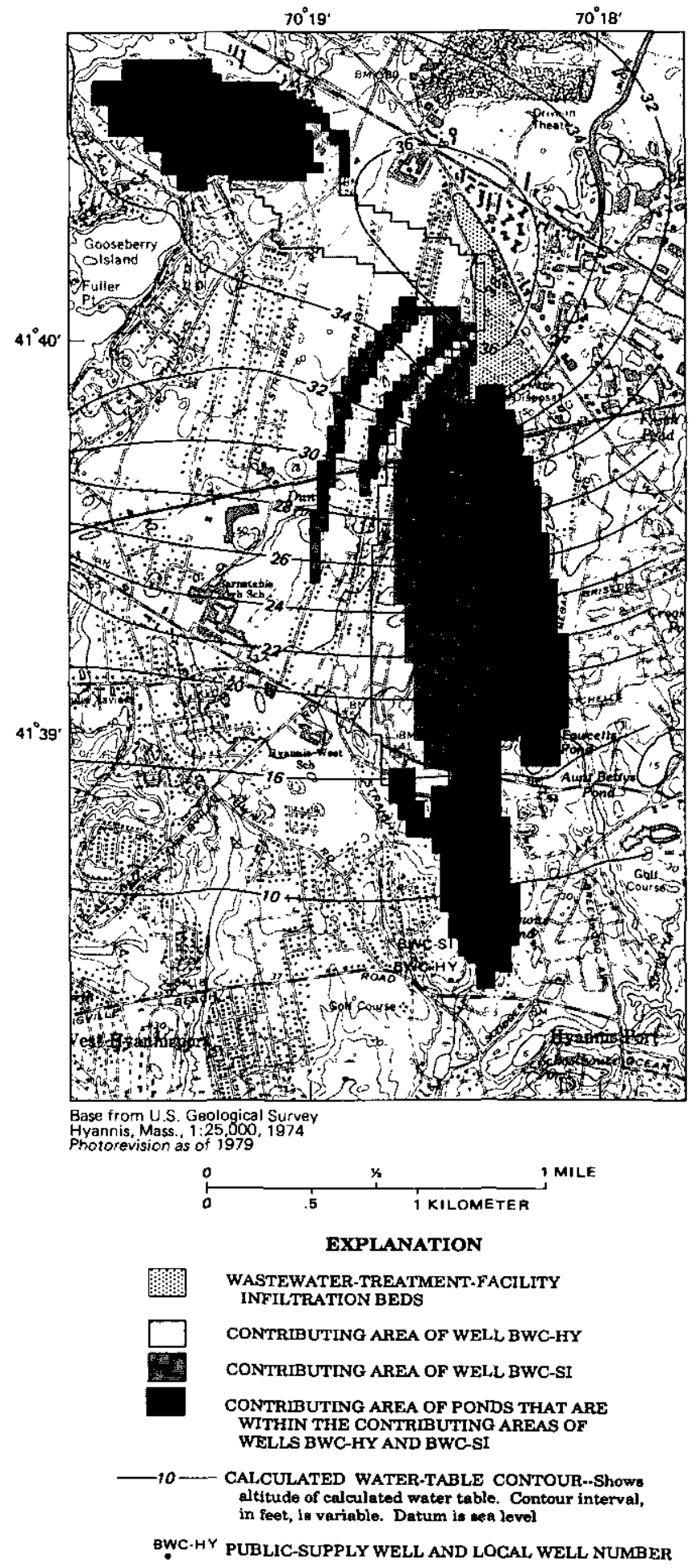

Figure 21. Contributing areas of wells BWC-HY and BWC-Sl and of ponds that are within the contributing areas of these wells for 1987 average daily pumping rates, determined by use of the three-dimensional model of the complex flow system.
(Other parameters are defined with equations 7 and 8 above.)

Wastewater return flow consists of discharge from septic systems within the flow system and a wastewatertreatment facility in Barnstable. Particles were determined to consist of septic-system return flow if the recharge rate specified for the cell in which the particle originated was greater than precipitation recharge but less than the recharge rate specified for cells underlying the infiltration beds of the wastewater-treatment facility. Particles were determined to consist of return flow from the treatment facility if the recharge rate specified for the cell in which the particle originated was equal to that specified for cells underlying the infiltration beds of the facility.

The type and quantity of wastewater retum flow captured by each well is shown in table 16 . Wastewater return flow from septic systems constitutes nearly 26 percent of total discharge for individual wells, and recharge from the wastewater-treatment facility seems to be a source of water to wells BWC-HY and BWC-SI. These computations were made by use of the option in which particles were stopped at weak sinks; they do not include particles that had passed through pond cells.

The quality of water discharged by the 15 wells was investigated to evaluate estimates of the volume of wastewater captured by each well. Nitrate (as nitrogen), an indicator of wastewater contamination, was used to evaluate the estimates of the volume of wastewater captured by each well. Water-quality samples were collected once at each well during 1987 as part of routine monitoring of the quality of water pumped by the wells. Mean background concentrations of nitrate (as nitrogen) in ground water beneath undeveloped land of Cape Cod are less than $0.1 \mathrm{mg} / \mathrm{L}$ (Frimpter and Gay, 1979). The highest nitrate concentrations were found in the discharge of wells for which estimates of the volume of captured wastewater were large (table 16, fig. 23). In 1987, nitrate concentrations in the discharge of wells that the model indicates capture wastewater from septic systems only ranged from 0.1 to $1.8 \mathrm{mg} / \mathrm{L}$, whereas nitrate concentrations in wells BWC-HY and BWC-SI that the model indicates capture wastewater from septic systems and the treatment facility were 2.9 and $4.7 \mathrm{mg} / \mathrm{L}$, respectively. A linear correlation was made between captured wastewater from septic systems and nitrate concentrations of well discharge for the 10 wells that the model indicates capture wastewater from septic 


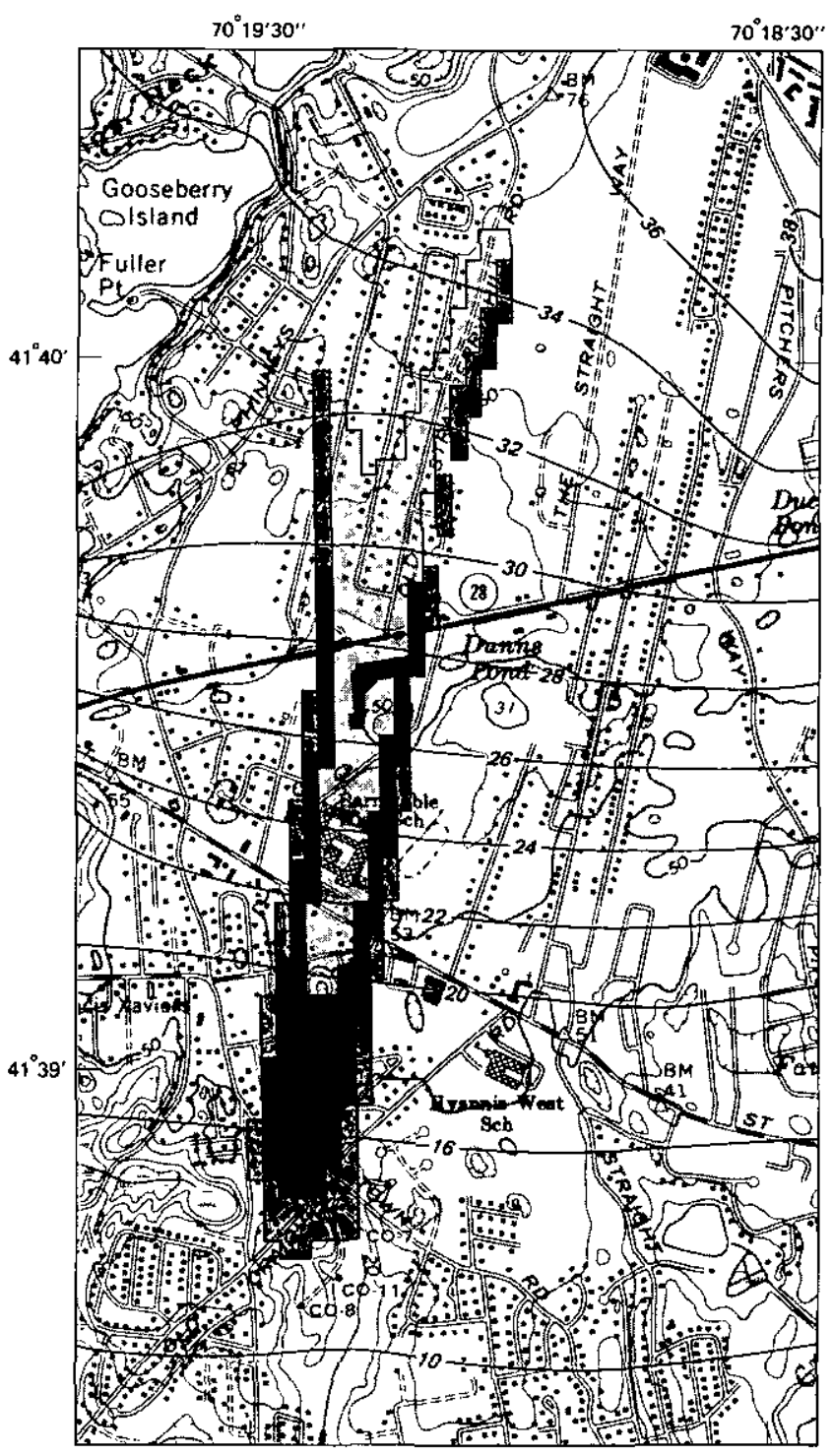

Base from U.S. Geological Survey

Hyannis, Mass., 1:25,000, 1974

Photorevision as of 1979

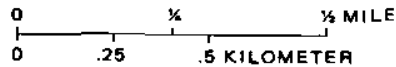

\section{EXPLANATION}

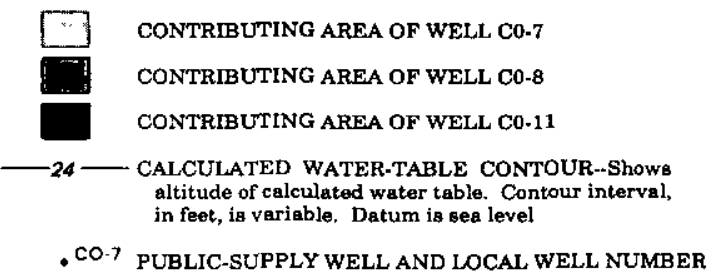

Figure 22. Contributing areas of wells $\mathrm{CO}-7, \mathrm{CO}-8$, and $\mathrm{CO}-11$ for 1987 average daily pumping rates, determined by use of the three-dimensional model of the complex flow system.
Table 16. Calculated captured wastewater from septic-system and treatment-facility sources as a percentage of well pumping rate, and measured nitrate concentrations in water samples from selected wells in the complex flow system, 1987

[mg/L, milligrams per liter; --, data not available]

\begin{tabular}{lccc}
\hline $\begin{array}{c}\text { Local } \\
\text { well } \\
\text { number }\end{array}$ & $\begin{array}{c}\text { Calculated } \\
\text { percentage } \\
\text { of pumping } \\
\text { rate from } \\
\text { septic systems }\end{array}$ & $\begin{array}{c}\text { Calculated } \\
\text { percentage } \\
\text { of pumping } \\
\text { rate from } \\
\text { treatment facility }\end{array}$ & $\begin{array}{c}\text { Measured } \\
\text { nitrate, as } \\
\text { nitrogen } \\
(\mathrm{mg} / \mathrm{L})\end{array}$ \\
\hline BWC-HY & 15.4 & 24.5 & 4.7 \\
BWC-SI & 10.9 & 22.0 & 2.9 \\
BFD-1 & 0 & 0 & .6 \\
BFD-2 & 1.3 & 0 & .7 \\
BFD-3 & .9 & 0 & .2 \\
BWC-AIR & 5.8 & 0 & -- \\
BWC-MD1 & 3.2 & 0 &.- \\
BWC-MD4 & 0 & 0 & .1 \\
BWC-MD2 & 2.4 & 0 & .1 \\
BWC-MD3 & 0 & 0 &.- \\
BWC-ME1 & 8.7 & 0 & .5 \\
BWC-ME2 & 7.8 & 0 & .5 \\
CO-7 & 24.7 & 0 & 1.8 \\
CO-8 & 22.2 & 0 & 1.6 \\
CO-11 & 25.7 & 0 & 1.7 \\
\hline
\end{tabular}

systems only (fig. 23). The linear correlation was computed by use of the nonparametric Kendall-Theil estimator for slope and intercept, which is valid for small sample sizes that may not be normally distributed. The significance of this correlation is measured by Kendall's tau correlation coefficient and was significant at the 0.03 level (Helsel and Hirsch, 1992).

Model results indicate that wells BWC-HY and BWC-SI capture wastewater originating at the treatment facility; however, water-quality data from observation wells downgradient from the facility are insufficient to unequivocally identify the wastewatertrealment facility as a source of wastewater to the wells. A plume of contaminated ground water has been mapped in the aquifer from the wastewater-treatment facility southeastward toward Aunt Betty's Pond (Cambareri, 1986), which is east of the contributing areas delineated for the two wells (fig. 21). Water-quality data presented by Cambareri $(1986$, p. 48$)$ also indicate the 


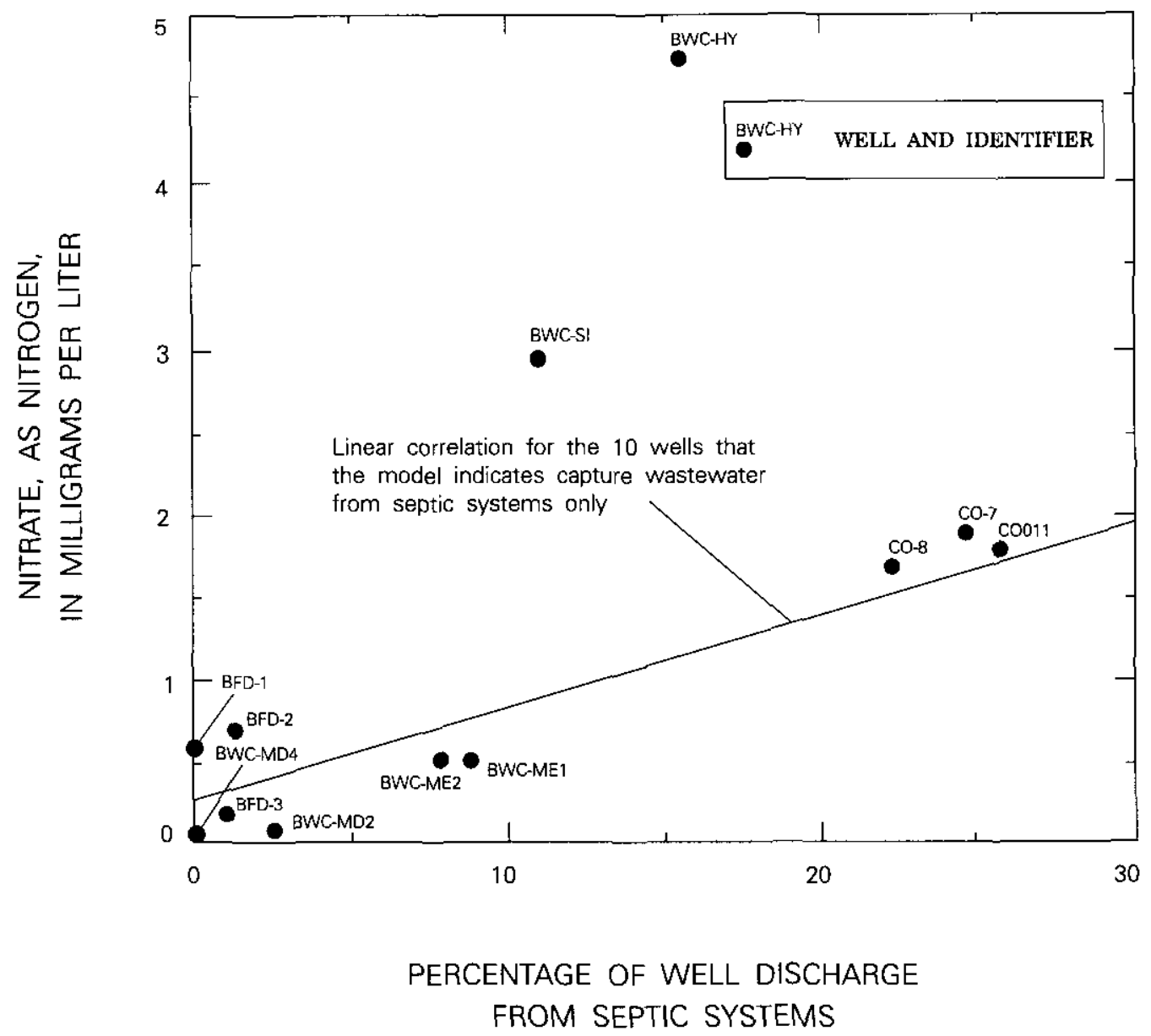

Figure 23. Calculated percentage of well discharge from septic systems, determined by the use of the three-dimensional model of the complex flow system, and nitrate concentrations in water from the wells in 1987.

presence of an oxidized zone of contamination west of the bulk of the contamination plume, west of Fawcett's Pond (which lies within the contributing areas delineated for the wells), and almost directly north of the wells that contains concentrations of nitrate (as nitrogen) ranging from 4.4 to $4.7 \mathrm{mg} / \mathrm{L}$. The western edge of the plume may be the source of high nitrate concentrations in the discharge of these wells; however, water-quality samples need to be collected from the aquifer near the western edge of the plume and upgradient from the two supply wells before a connection between the facility infiltration beds and the pumped wells can be established.

\section{Sensitivity of Contributing Areas to Selected Factors}

Seven simulations were completed to determine the effect of selected model parameters and discretization to the delineation of contributing areas to the 15 supply wells. The simulations reported are for an increase and a decrease in the conductance of streambed materials (simulations 1 and 2), a reduction in the hydraulic conductivity of fine-grained sediments of eastern Barnstable (simulation 3 ), a redistribution of wastewater return flow from septic systems to the wastewater-treatment facility (simulation 4 ), a reduction in the depth of simulated ponds and in the vertical hydraulic conductivity of pond-bottom sediments (simulations 5 and 6 ), and simulation of the flow system with the two-dimensional model (simulation 7).

During development of the three-dimensional model of the complex flow system it was noted that flow rates to streams and hydraulic gradients in the simulated aquifer are sensitive to the specification of streambedconductance terms. Because some of the supply wells in 
the flow system are near streams, contributing areas delineated for these wells could be expected to be sensitive to the specification of this parameter. The effect of changes in streambed conductance on the delineation of contributing areas was assessed by first uniformly increasing and then uniformly decreasing the conductance of streambed sediments by one order of magnitude in the first two sensitivity tests. Contributing areas of the 15 wells were minimally affected by changes in the specification of streambed conductance and are not shown. These results are likely due to the fact that most streams in the flow system are downgradient from or lateral to the wells. Consequently, though the values of streambed conductance specified in the model are not known precisely, the uncertainty associated with them is unimportant to the delineation of contributing areas to these 15 wells.

\section{Hydroulle Conductivlty of Fine-Grained Sediments of Eastern Barnstable}

A sensitivity test done during the development of the three-dimensional model of the complex flow system indicated that the mean error between observed and calculated heads at 66 observation points in the aquifer shifted from +0.53 to $-0.43 \mathrm{ft}$ when the horizontal hydraulic conductivity and vertical conductance of the fine-grained silt and clay of eastern Barnstable were decreased by one order of magnitude. Because of the uncertainty associated with the hydraulic conductivity of these sediments, and because contributing areas are likely to be affected by the values of hydraulic conductivity used to represent these sediments, a simulation was done in which the horizontal and vertical hydraulic conductivities of these sediments were uniformly decreased by one order of magnitude from the calibrated values (from $0.01 \mathrm{ft} / \mathrm{d}$ to $0.001 \mathrm{ft} / \mathrm{d}$ ).

A comparison between contributing areas delineated for six wells west of the wastewater-treatment facility (BWC-HY, BWC-SI, BFD-3, CO-7, CO-8, and CO-11, fig. 24) with those delineated by use of the calibrated model (fig. 20) indicates that the change in hydraulic gradient produced by the reduction in the hydraulic conductivity of these sediments affects contributing areas of these wells; contributing areas delineated for the remaining nine wells, however, were not significantly affected and are not shown. Results of the simulation also indicate that Wequaquet Lake is a source of water to the six wells and that the wastewater-treatment facility is a source of water to wells BWC-HY, BWC-SI,
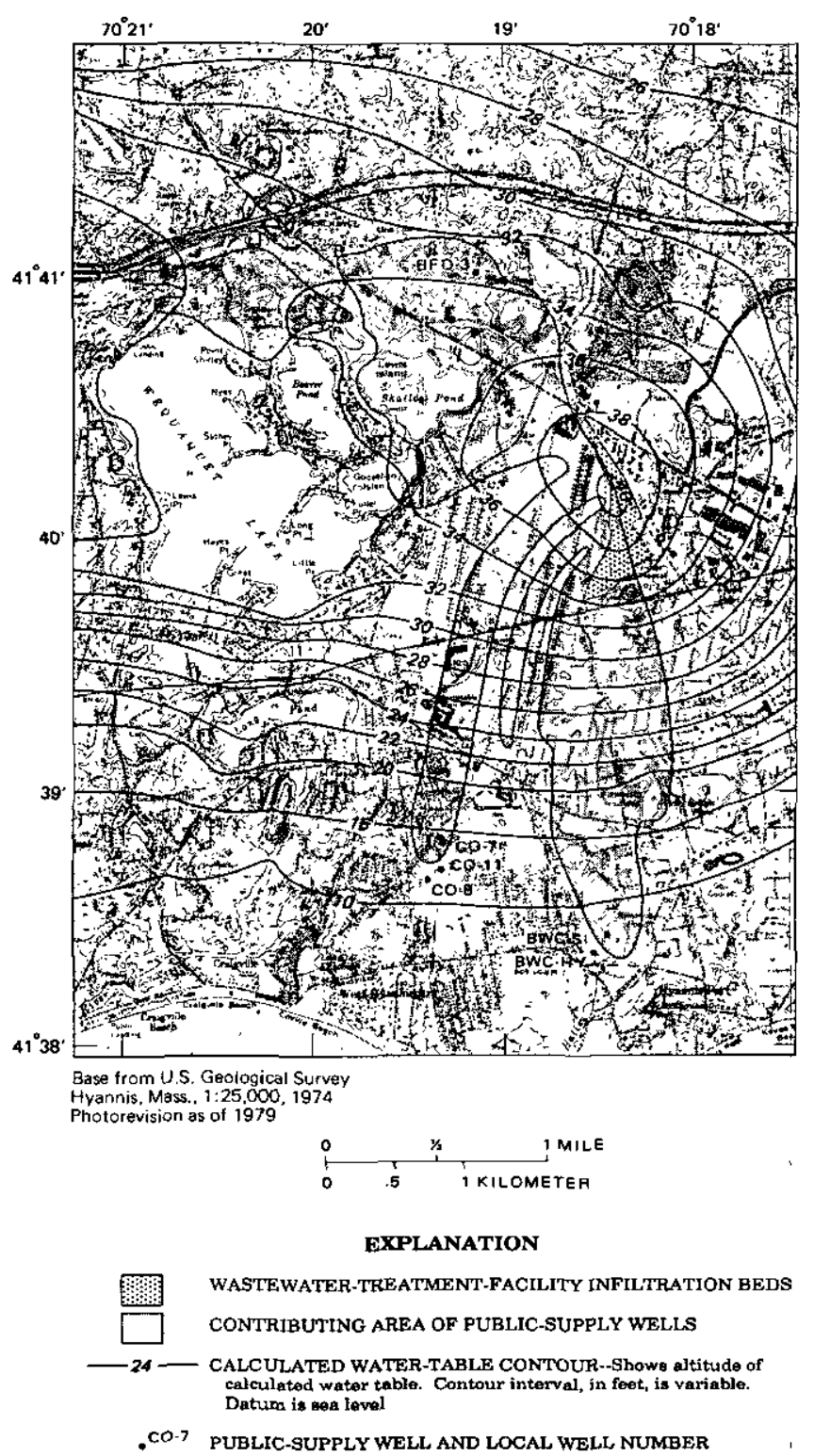

Figure 24. Contributing areas of six public-supply wells from simulation of a reduction in the hydraulic conductivity of fine-grained sediments of eastern Barnstable, determined by use of the three-dimensional model.

BWC-ME1, and CO-7. Uncertainty in the hydraulic conductivity of these fine-grained sediments therefore leads to significant uncertainty in the delineation of contributing areas and the source of water to several of the simulated wells.

\section{Distribution of Wasfewater Return Flow}

The influence of the rate and location of wastewater return flow on the delineation of contributing areas and 
sources of water to the 15 supply wells was assessed by a simulation in which all public water supplied to residential dwellings and commercial facilities in the area of the model east of Wequaquet Lake (coincident with column 21 of the model) and west of the BarnstableYarmouth town line was assumed to be collected by sewers, treated at the wastewater-treatment facility, and infiltrated there. Model cells within this subarea that received wastewater return flow from septic systems in the calibrated model were assigned a recharge rate equal to the long-term average precipitation recharge rate of $18.9 \mathrm{in} / \mathrm{yr}$, and all water that would have recharged the aquifer through septic systems entered the aquifer at the treatment facility. The discharge rate to the treatmentplant infiltration beds for these conditions is $3.6 \mathrm{Mgal} / \mathrm{d}$-approximately $0.6 \mathrm{Mgal} / \mathrm{d}$ less than the $4.2-\mathrm{Mgal} / \mathrm{d}$ design capacity of the facility.

The location and size of contributing areas delineated for the wells, and the percentage of wastewater return flow captured by the 15 wells, are affected by the location and rate of wastewater return flow simulated in this example. Contributing areas delineated for the six wells most affected by these changes (wells BWC-HY, BWC-SI, BFD-3, and CO-7, CO-8, and CO-11) are shown in figure 25 . The percentage of return flow from septic systems captured by the 15 wells is zero for all wells except two that are on the border between sewered and unsewered areas. Although retum flow from septic systems is reduced to zero, the volume of wastewater return flow from the treatment facility captured by wells BWC-HY and BWC-SI is increased, and two wells (CO-7 and $\mathrm{CO}-8$ ) that did not capture water from the treatment facility for the 1987 pumping and recharge conditions do so in this simulation. The larger volume of wastewater infiltrated at the treatment facility raises heads near the facility and changes the direction of hydraulic gradients near the facility such that a larger proportion of the aquifer downgradient from the plant is affected by the infiltrated water. In addition, the increased volume of wastewater discharged from the facility increases the flow of wastewater southward toward Nantucket Sound, and, consequently, increases the volume of wastewater captured by wells BWC-HY and BWC-SI from that of the base simulation.

This simulation indicates that the distribution of wastewater return flow within the flow system has an important effect on the source of water to individual

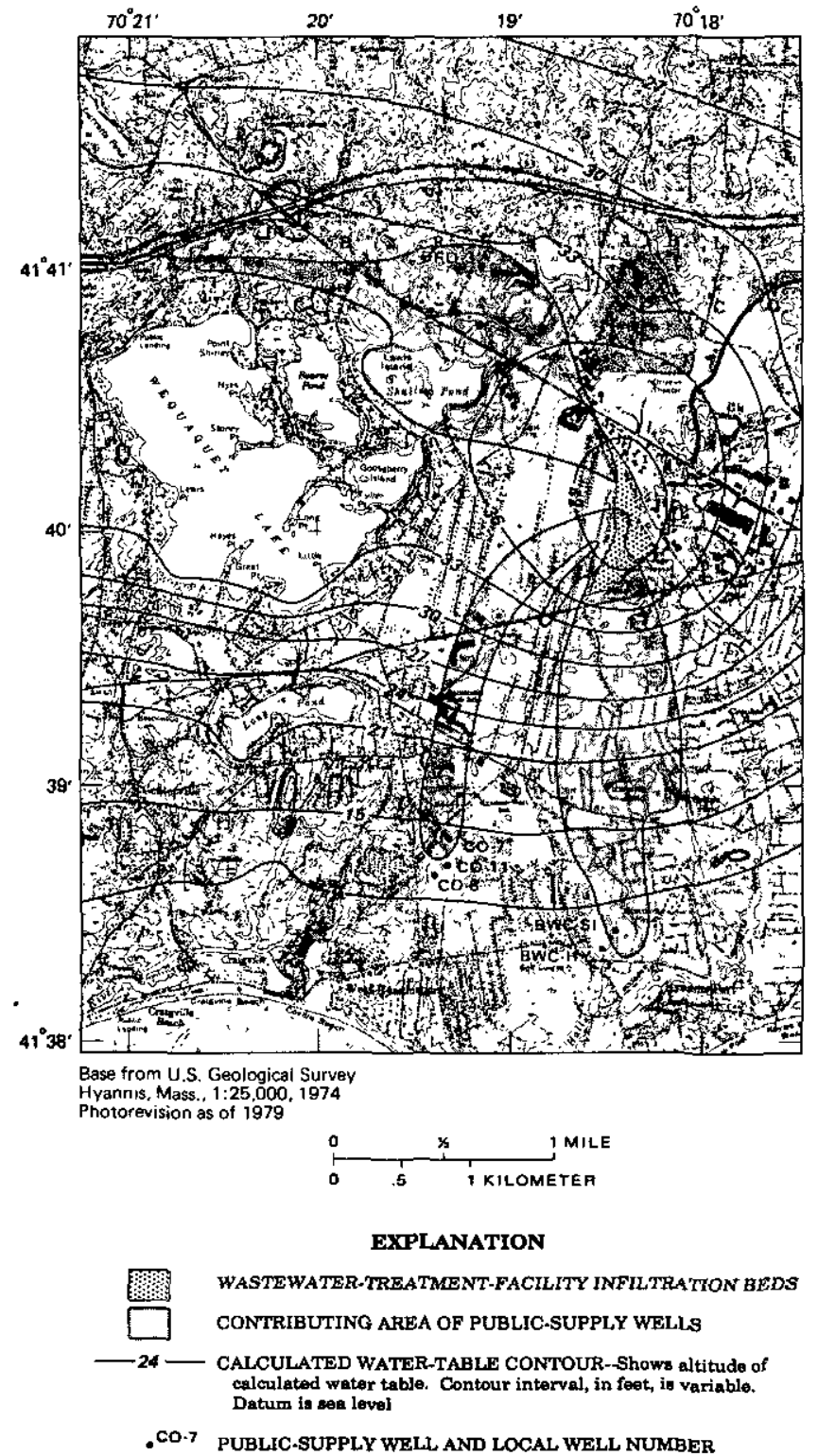

Figure 25. Contributing areas of six public-supply wells from simulation of a redistribution of wastewater return flow from septic systems to the wastewoter-treatment facility in the complex flow system, determined by use of the threedimensional model.

wells. Simulations such as this are useful for assessing alternative wastewater-management strategies on the source of water to public-supply wells.

\section{Pond Depth and Vertical Hydraulic Conductivity of Pond-Bottom Sediments}

Ponds are an important component in the delineation of contributing areas to the 15 wells in the complex flow system. The representation of ponds in the flow model, 
however, required that their behavior be somewhat simplified. As discussed in the development of the flow models, ponds were only simulated in the top layer of the three-dimensional models. It was noted, however, that simulated ponds, on average, extend deeper into the aquifer than do real ponds in the flow systems. The effect of the depth of simulated ponds on contributing areas and source of water for the 15 wells was investigated by a simulation in which the top layer of the eight -layer calibrated model was divided into two layers. The upper layer of the new model extended from the water table to sea level and the second layer extended to $10 \mathrm{ft}$ below sea level. Ponds were again simulated by assigning a horizontal hydraulic conductivity of $50,000 \mathrm{ft} / \mathrm{d}$ to cells of the top layer of the nine-layer model that underlie ponds. Cells below ponds in layer 2 of this nine-layer model were assigned a horizontal hydraulic conductivity of $150 \mathrm{ft} / \mathrm{d}$, a typical value of the horizontal hydraulic conductivity of sediments represented in layer 1 of the eight-layer model. The hydraulic conductivity of all other non-pond cells in layers 1 and 2 of this nine-layer model were assigned horizontal hydraulic conductivities equal to those specified for layer 1 of the eight-layer model. A uniform vertical conductance between layers 1 and 2 of the nine-layer model of $1.0 \mathrm{day}^{-1}$, representative of the conductance between layers 1 and 2 of the eight-layer model, was assigned to all cclls. Head-dependent flux boundaries used to represent Wequaquet Lake and streams were located in the top layer of the nine-layer model, and the layer from which each well was pumped was changed to be consistent with the new layering scheme.

A second simulation was then completed to assess the influence of the vertical hydraulic conductivity of pond-bottom sediments on the delineation of contributing areas, by use of the original eight-layer model. During development of that model, the vertical hydraulic conductivity of pond cells was specified on the basis of lithologic logs of test holes near the ponds, and the vertical hydraulic conductivity of pond-bottom sediments was not reduced to account for organic matter and fine-grained sediments that tend to accumulate on the bottom of ponds. Because these pond-bottom sediments tend to lower vertical hydraulic conductivity, they may reduce the total downward flow of water into the aquifer and may affect the movement of water to supply wells. This effect of bottom sediments may be particularly important for wells such as BWC-HY and
BWC-SI that are screened in deeper layers of the aquifer and capture part of their discharge from pond throughflow. In this second simulation, the vertical hydraulic conductivity of pond cells was reduced by one order of magnitude from values of the calibrated model, which corresponds to a tenfold reduction in the vertical hydraulic conductivity of sediments lying between the ponds and the underlying aquifer.

Contributing areas delineated for the 15 wells for these two simulations were nearly identical to those determined for the eight-layer, calibrated model and are not shown. The calculated percentage of discharge of each well that is from pond throughflow also was similar to those determined for the calibrated model. The largest change was for well BWC-SI, where 52.3 percent of the discharge was derived from pond throughflow in the calibrated model, but only 42.2 percent was from pond throughflow in the nine-layer model, and only 39.9 percent was from pond throughflow when the hydraulic conductivity of pond-bottom sediments was reduced. These results indicate that, overall, simulated pond depth and vertical hydraulic conductivity of pond-bottom sediments are not particularly critical parameters in the delineation of contributing areas to wells in the flow system.

\section{Vertical Discretization of Flow Model}

A simulation was completed by use of the twodimensional flow model of the complex flow system in which the 34 supply wells in the study area were pumped at their 1987 average daily pumping rates (table 12). Contributing areas again were delineated for 15 of these wells by tracking particles in the forward direction from the water table to the pumping wells. A two-by-two array of particles was specified for the top face of each cell in the model. Two particle-tracking runs were completed by use of both weak-sink options.

Contributing areas delineated for 7 of the 15 wells most affected by the use of a two-dimensional model are shown in figure 26 . Because the two-dimensional model has no vertical flow components, it is limited in its ability to simulate many of the hydrogeologic factors and well-design characteristics that affect the threedimensional flow of water to these 15 supply wells, including vertically anisotropic and heterogeneous sediments with ratios of horizontal to vertical hydraulic conductivity more representative of glacial moraine 


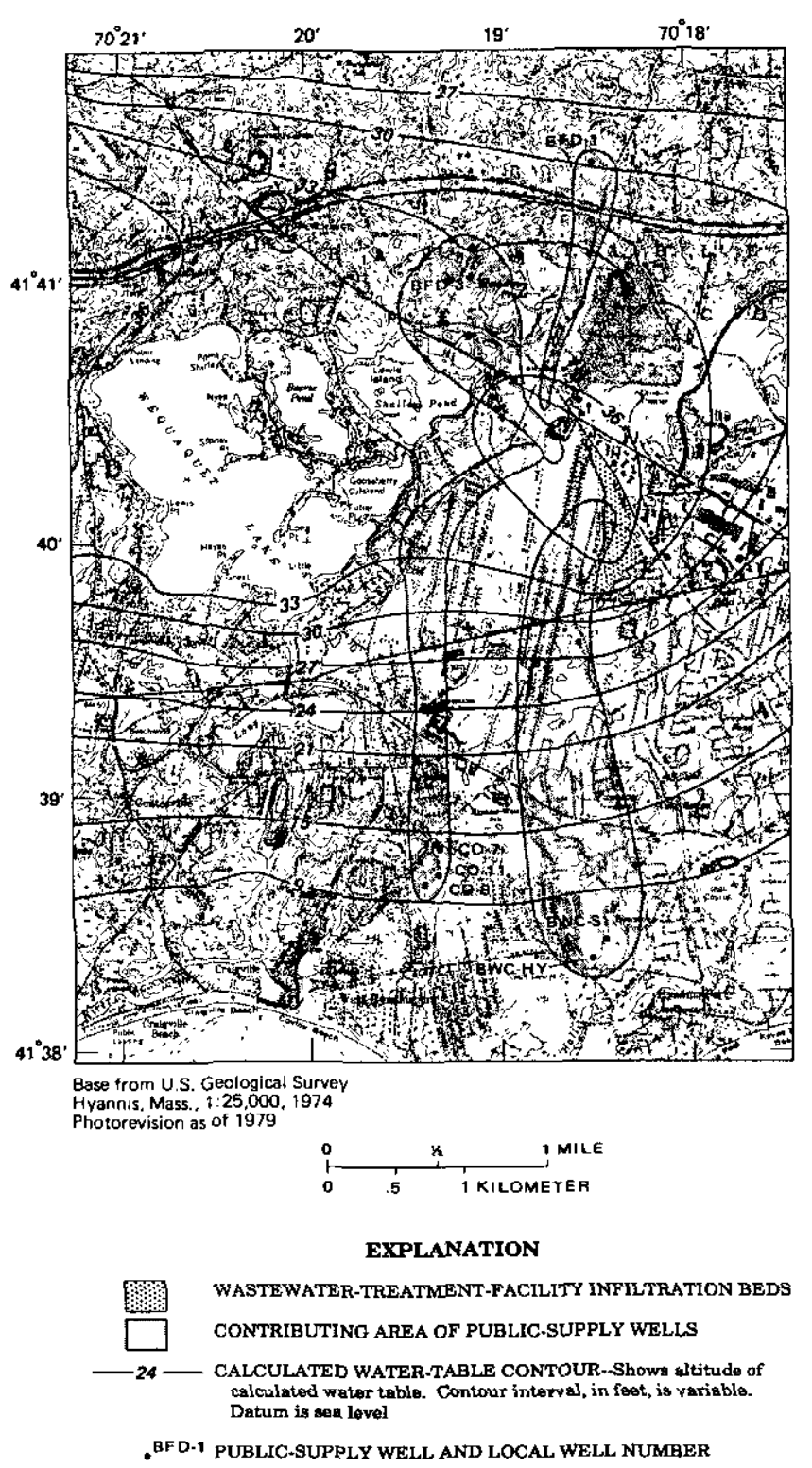

Figure 26. Contributing areas of seven publicsupply wells in the complex flow system for 1987 average daily pumping rates, determined by use of the two-dimensional model.

than stratified drift, partial penetration of well screens, and low pumping rates. In addition, calculated pumping rates for the 15 wells (table 17) for the two weak-sink options indicate that 11 of the wells are affected by weak sinks (all wells except BFD-2, BFD-3, BWCAIR, and BWC-MD4) and 7 of the wells are themselves weak internal boundary sinks (BFD-1, BWC-MD1, BWC-MD3, BWC-ME1, CO-7, CO-8, and CO-11). Calculated pumping rates for the 15 wells range from 0 to 148.5 percent of specified discharge rates when particles are allowed to pass through weak sinks, and 47.2 to 240.7 percent of specified discharge rates when particles are stopped at weak sinks (table 17). These calculated pumping rates indicate that weak sinks cause a much greater range of variability in the contributing area delineated for the 15 wells than they do in those areas delineated by the three-dimensional model at comparable recharge and pumping conditions. For example, the contributing area delineated for well BFD -1 by use of the two-dimensional model (fig. 26) is much larger in size and very different in shape and location than that delineated by use of the three-dimensional model (fig. 20). The variability in the calculated pumping rates results from the fact that the single-layer model does not adequately simulate the effects of weak sinks on the ground-water-flow system. A vertical discretization of the flow system that includes an improved representation of the screened interval of these wells and of the head-dependent flux boundaries used to represent the shallow streams and Wequaquet Lake, such as is provided by the three-dimensional model, is required for adequate delineation of contributing areas of these wells. Differences between contributing areas delineated by the two-dimensional model (fig. 26) and those delineated by use of the three-dimensional model (fig. 20) also result from the different methods used to represent ponds in each model.

In summary, contributing areas of public-supply wells in this relatively complex flow system are better defined by use of the three-dimensional model than they are by the two-dimensional model, because the threedimensional model is more able to represent those factors that affect three-dimensional flow to the wells.

\section{DATA REQUIREMENTS FOR AND LIMITATIONS OF PARTICLE TRACKING FOR DELINEATION OF CONTRIBUTING AREAS}

Particle tracking was shown to be an effective tool for delineation of contributing areas to public-supply wells pumping from the simple and complex flow systems, even when such factors as spatial variability of recharge, aquifer heterogeneity, partial penetration of wells, and non-ideal boundary conditions complicate the delineation process. The method has several limitations, however, that affect the accuracy with which contributing areas may be defined. Morcover, the method requires a large amount of data that must be collected and analyzed, particularly for three-dimensional simulations. The following section outlines data 
Table 17. Specified pumping rates and pumping rates calculated by use of the two-dimensional model for selected wells in the complex flow system

[Pumping rates are shown in cubic feet per day]

\begin{tabular}{|c|c|c|c|c|c|}
\hline \multirow[b]{2}{*}{$\begin{array}{l}\text { Local } \\
\text { well } \\
\text { number }\end{array}$} & \multirow[b]{2}{*}{$\begin{array}{l}\text { Specified } \\
\text { pumping } \\
\text { rate }\end{array}$} & \multicolumn{2}{|c|}{ Particles passed through weak sinks } & \multicolumn{2}{|c|}{ Particles stopped at weak sinks } \\
\hline & & $\begin{array}{c}\text { Calculated } \\
\text { pumping rate }\end{array}$ & $\begin{array}{l}\text { Percentage of } \\
\text { specified } \\
\text { pumping rate }\end{array}$ & $\begin{array}{c}\text { Calculated } \\
\text { pumping rate }\end{array}$ & $\begin{array}{l}\text { Percentage of } \\
\text { specified } \\
\text { pumping rate }\end{array}$ \\
\hline BWC-HY & 50,800 & 50,900 & 100.2 & 43,000 & 84.6 \\
\hline BWC-SI & 94,900 & 94,600 & 99.7 & 44,800 & 47.2 \\
\hline BFD-1 & 2,700 & 0 & 0 & 6,500 & 240.7 \\
\hline BFD-2 & 24,100 & 23,500 & 97.5 & 23,500 & 97.5 \\
\hline BFD-3 & 38,800 & 38,700 & 99.7 & 38,700 & 99.7 \\
\hline BWC-AIR & 30,800 & 31,900 & 103.6 & 31,900 & 103.6 \\
\hline BWC-MD1 & 12,000 & 0 & 0 & 12,900 & 107.5 \\
\hline BWC-MD4 & 36,100 & 36,100 & 100.0 & 36,100 & 100.0 \\
\hline BWC-MD2 & 36,100 & 53,600 & 148.5 & 32,300 & 89.5 \\
\hline BWC-MD3 & 5,300 & 0 & 0 & 8,300 & 156.6 \\
\hline BWC-ME 1 & 24,100 & 0 & 0 & 34,500 & 143.2 \\
\hline BWC-ME2 ${ }^{1}$ & 104,300 & 126,200 & 121.0 & 74,600 & 71.5 \\
\hline $\mathrm{CO}-7$ & 17,400 & 0 & 0 & 26,200 & 150.6 \\
\hline $\mathrm{CO}-8^{2}$ & 9,400 & 0 & 0 & 11,500 & 122.3 \\
\hline $\mathrm{CO}-11$ & 13,400 & 0 & 0 & 14,800 & 110.4 \\
\hline
\end{tabular}

${ }^{1}$ Well includes discharge from both BWC-ME2 and BWC-ME3.

${ }^{2}$ Screened interval of well extends over two layers of the three-dimensional model.

requirements and limitations for each of the steps needed to delineate the contributing area of a well by use of particle tracking: analysis of the hydrogeology and development of a conceptual model of the flow system, development of a numerical model of groundwater flow, and particle-tracking analysis. Emphasis is placed on identifying data requirements and limitations with respect to the two flow systems investigated in this study.

Data requirements of a three-dimensional steadystate analysis of the contributing area of a well tapping a stratified-drift aquifer include (1) information on the geologic framework and boundary conditions of the aquifer; (2) horizontal and vertical hydraulic conductivity and porosity of the aquifer; (3) characteristics that control the exchange of water between the aquifer and surface-water bodies; (4) spatial distribution and rate of ground-water recharge, location of pumping centers, and rate of pumping; and (5) maps that show the vertical and horizontal distribution of head in the aquifer. Of these, all except the vertical hydraulic conductivity of the aquifer is needed for a two-dimensional model.

Hydrogeologic data available for the simple and complex flow systems included water-table-altitude maps and a few measurements of vertical hydraulichead gradients, estimates of horizontal and vertical hydraulic conductivity of coarse-and fine-grained stratified drift, estimates of porosity for similar stratified drift elsewhere on Cape Cod, estimates of the distribution of recharge from precipitation and wastewater return flow and actual or proposed pumping rates and well locations, more than 400 lithologic logs, seismicrefraction data on the altitude of bedrock, and data on the altitude of surrounding coastlines. There were more than 10 times the number of lithologic logs available for the complex flow system than there were for the simple flow system, and, in general, the lithology of the complex flow system has been defined in greater detail than that of the simple flow system. The data were limited in that they did not include estimates of the conductance of streambed sediments, the vertical hydraulic 
conductivity of pond- and lake-bottom sediments, or estimates of the hydraulic conductivity of the finegrained unit of eastern Barnstable. Furthermore, lithologic information was sparse in some areas of the flow systems and, where present, commonly did not include a complete vertical description of the geology, especially with respect to the thickness and distribution of the fine-grained unit in eastern Barnstable and the type and thickness of underlying deposits.

The development of the conceptual models of the ground-water-flow systems was based on an analysis of all available hydrogeologic data, including information on the geologic framework and boundary conditions of the flow systems. Errors introduced in the development of a conceptual model may be reduced as additional data are collected and the understanding of the flow system improves.

Two of the first steps that must be made in the development of a ground-water-flow model are (1) whether or not the flow problem requires steady-state or transient simulation and analysis and (2) whether the system is best represented by a two- or three-dimensional model. The steady-state analyses chosen for this study limit the delineation of contributing areas to pumping and recharge conditions that are assumed to take place over a period of time sufficient for equilibrium conditions to be established and for all particles to reach the simulated wells. The decision to use steady-state simulations was made because of time constraints of the investigation and because the particle-tracking algorithm used in the analysis currently does not simulate transient conditions. The steady-state models developed for this study cannot be used to assess the transient development of contributing areas for simulated wells resulting from short periods of high stress (such as those on Cape Cod in the summer when pumping rates are highest and recharge rates are near zero) or from longterm changes in pumping from the flow systems (such as occur as a flow system is developed). Each of these two situations are likely to be important factors to the delineation of contributing areas of wells in the simple and complex flow systems and in similar stratified-drift aquifers.

Two- and three-dimensional models were both used to represent the flow systems. Results of the investigation indicate that model choice depends largely on the complexity of the flow system tapped by the well.
Contributing areas defined for wells in the simple flow system indicate that two-dimensional analytical and numerical models may be adequate for the delineation of contributing areas for large-capacity wells (greater than $0.25 \mathrm{Mgal} / \mathrm{d}$ ) pumping from that single-layer and uniform aquifer with near-ideal boundary conditions. Several of the contributing areas delineated by use of the three-dimensional models of both systems, however, did not conform to simple ellipsoidal shapes that are typically delineated by use of two-dimensional analytical and numerical modeling techniques, included discontinuous areas of the water table, and did not surround the wells. Because two-dimensional areal models do not account for vertical flow, they cannot adequately represent many of the hydrogeologic and well-design variables that were shown to complicate the delineation of contributing areas in these systems, including the presence of discrete lenses of low hydraulic conductivity, ratios of horizontal to vertical hydraulic conductivity greater than ratios for stratified-drift aquifers, shallow streams, partially penetrating supply wells, low (less than about $0.1 \mathrm{Mgal} / \mathrm{d}$ ) pumping rates, and spatial variability of recharge rates. Under these conditions, accurate delineation of contributing areas may require the use of a three-dimensional model.

The limitations to the use of numerical models coupled with particle tracking for the delineation of contributing areas include limitations caused by uncertainty in the definition of boundary conditions, stresses, and model parameters; limitations caused by discretization of the flow system by a finite-difference grid; and limitations in the data base used for model calibration. In addition, certain limitations are caused by the underlying assumptions of the numerical-model and particle-tracking algorithms themselves.

Poorly or incorrectly defined boundary conditions and model stresses can lead to simulated heads and flows that are inconsistent with the natural system. For example, the use of specified-head or head-dependent flux boundaries to simulate streams, ponds, or lakes can result in unrealistically large volumes of water entering a flow model at these boundaries, which may result in erroneous sources of water to the wells and contributing areas that are smaller than those that would have been delineated had the boundary sources not contributed water to the model. This was the primary reason that specified-head cells were not used to simulate ponds. In addition, the use of impermeable (no-flow) boundaries 
to simulate ground-water divides may incorrectly restrict the contributing area of a well to the modeled area. Inadequate definition of the interface between freshwater and saltwater may be a source of error in the delineation of contributing areas to supply wells investigated during this study. Because most wells simulated in the models were shallow wells with finished depths less than $75 \mathrm{ft}$ below sea level and no closer than $0.5 \mathrm{mi}$ from the discharge boundaries of the aquifers, it is assumed that the specification of the interface boundary does not have a significant effect on simulated heads or flow rates, and, therefore, on the delineation of contributing areas of the wells. Other boundary conditions and stresses that may have been incorrectly defined are recharge rates to the aquifer and the headconductance terms specified for simulated streams and Wequaquet Lake.

Limitations caused by uncertainty in hydraulic parameters of the model arise because aquifer properties and recharge rates are commonly only best estimates of the true values at only a few sites in the aquifer and must be extrapolated to areas of the model for which no data are available. Although hydraulic conductivity and recharge rates were estimated for the two flow systems by means of established methods, some error is associated with each parameter estimate that is typically undefined. Because the effects of the two variables on the ground-water-flow systems are related (fig. 7), and because discharge rates along the coasts are not known, improved estimates of one of the parameters would improve estimates of the other. The uncertainty associated with the hydraulic conductivity of the fine-grained unit in eastem Barnstable was shown to be an especially important source of uncertainty to contributing areas delineated for wells in the westem part of the complex flow system.

The discretization used in a ground-water-flow model affects (1) the level of detail at which hydrogeologic and system boundaries can be represented, (2) the accuracy of velocity calculations, and (3) the accuracy to which internal boundary sinks can be represented (Pollock, 1989, p. 19). As discussed by Pollock (1989, p. 19), a discretization that may be adequate for assessing regional water-supply concerns may not be adequate for a pathline analysis because velocity computations made by MODPATH are affected by the degree to which internal boundaries are represented. The flow models developed for this study consist of horizontal grid dimensions that are a minimum of 264 by
$264 \mathrm{ft}$ near the production wells; the smallest vertical discretization used in the three-dimensional models for layers in which wells are simulated is $10 \mathrm{ft}$. The grid discretization used in these models is much fincr than those used for models that have been developed previously for Cape Cod to evaluate hydrologic effects of regional water development and waste disposal (Guswa and LeBlanc, 1985, p. 1). Contributing areas delineated for hypothetical wells in the simple flow system were unaffected by the scale of discretization of internal boundary sinks because the only sinks simulated by the two- or three-dimensional models were supply wells that captured all water flowing into the cells in which they were located. Contributing areas to several wells in the complex flow system were affected by weak internal boundary sinks; weak internal boundary sinks affected contributing areas delineated by use of the two-dimensional model more than they did those delineated by use of the three-dimensional model.

Finally, some limitations are caused by errors and inadequacies in the data base used for model calibration. If the data to which the steady-state model is bcing calibrated either are not representative of average conditions in the aquifer or do not contain an adequate number of data points, model parameters fitted to the data set during calibration will be incorrect. Calibration data used in the development of the models reported here consisted only of heads measured in wells in each of the flow systems during periods when water levels in longterm observation wells were near their average levels. The water-table maps developed from this data are felt to be representative of average conditions in the aquifer, yet they are only an approximation of the true average conditions and do not include many measurements of head deeper than the water table.

\section{SUMMARY AND CONCLUSIONS}

The degradation of ground-water quality caused by human activities can have profound effects on the health and economic viability of communities that depend on ground water for their domestic, industrial, and agricultural needs. Protection of ground-water resources is therefore becoming an integral part of State and Federal strategies for continued maintenance of the quality of public water supplies. To protect ground water pumped by public-supply wells, Congress established the Wellhead Protection Program through the 1986 amendments to the Safe Drinking Water Act of 1974. As part of these 
amendments, States are required to determine the land area that contributes water to public-supply wells within their jurisdiction and to enact programs to prevent contamination of ground-water resources underlying these areas.

The ground-water-flow system of Cape Cod, Mass. is typical of shallow, highly permeable, stratified-drift aquifers susceptible to contamination from domestic, industrial, and agricultural sources. A recent analysis of contributing areas delineated for public-supply wells of Cape Cod indicated that analytical-modeling techniques that had been used for delineation of contributing areas to the nearly 200 supply wells of Cape Cod could not account for all of the complex hydrogeologic interrelations that affect the delineation of contributing areas, including aquifer heterogeneity; spatial variability of recharge rates; non-ideal boundary conditions; and multiple, partially penetrating supply wells with variable discharge rates. Consequently, the Aquifer Assessment Committee of the Cape Cod Aquifer Management Project (1988) recommended that a study be done to demonstrate the use of and to assess the effectiveness and limitations of numerical-flow modeling coupled with particle tracking for delineation of contributing areas for existing and hypothetical supply wells pumping from two flow systems that represent the range of hydrogeologic complexity of flow systems of Cape Cod. The first system (the simple flow system) consists of a thin (up to $100 \mathrm{ft}$ ), single-layer aquifer with near-ideal boundary conditions and no large-capacity public-supply wells. The second system (the complex flow system) consists of a thick (approximately 250 to $500 \mathrm{ft}$ ), multilayered aquifer with non-ideal boundary conditions (including streams, ponds, and spatial variability of recharge rates) from which 32 partially penetrating public-supply wells currently (1987) pump water.

Steady-state, two- and three-dimensional groundwater-flow models were developed for each system to compare and contrast contributing areas delineated from each of the two vertical-layering schemes. These models were based on available hydrogeologic and well-design data and a conceptual model of groundwater flow in each system. The three-dimensional model of the simple flow system consists of five layers, whereas that of the complex flow system consists of eight layers. The vertical discretization of each of the three-dimensional models was guided by the screened interval of supply wells and hydrogeologic framework of each of the flow systems; each of the three-dimensional models extends from the water table to the contact between glacial sediments and underlying bedrock. The two-dimensional model of the simple flow system extends from the water table to the contact between an upper coarse-grained aquifer and an underlying finegrained confining unit; the two-dimensional model of the complex flow system extends from the water table to the contact between glacial sediments and underlying bedrock.

Each of the four models receives recharge at the water table, and each is bounded laterally in most areas by coastal saltwater boundaries that were represented as specified-head boundaries. Recharge from precipitation is the only source of water to the models of the simple flow system, whereas recharge from precipitation and wastewater return flow (from septic systems and a wastewater-treatment facility) and leakage through a head-dependent flux boundary at Wequaquet Lake are the sources of water to models of the complex flow system. Several small streams in the complex flow system that are locations of ground-water discharge were represented by head-dependent flux boundaries. Ponds, which are connected hydraulically with the aquifers, were represented as areas of very high hydraulic conductivity $(50,000 \mathrm{ft} / \mathrm{d})$, to simulate their dampening effect on heads in the aquifers.

Values of hydraulic conductivity for each model were estimated from aquifer and permeameter tests. Horizontal hydraulic conductivity of coarse-grained (sand and gravel) stratified drift, estimated by analysis of several aquifer tests on Cape Cod, ranges from approximately $160 \mathrm{ft} / \mathrm{d}$ for fine sand to $300 \mathrm{ft} / \mathrm{d}$ for coarse to very coarse sand; the ratio of horizontal to vertical hydraulic conductivity ranges from about $1: 1$ to 10:1 for medium to coarse sand and gravel to $30: 1$ for fine sand. The horizontal and vertical hydraulic conductivity of silt and clay from the confining unit of the simple flow system, estimated from permeameter tests, ranges from about $10^{-5}$ to $10^{-3} \mathrm{ft} / \mathrm{d}$. Estimated porosity, which is needed to determine particle velocities, was about 0.39 based on tracer tests in coarse-grained stratified drift and about 0.68 based on permeameter tests of silt and clay cores.

The four models were calibrated to heads measured in each flow system during periods of near-average hydrologic conditions. Total steady-state inflow to the 
models of the simple flow system is about $22 \mathrm{ft}^{3} / \mathrm{s}$; total steady-state inflow to the models of the complex flow system is about $80 \mathrm{ft}^{3} / \mathrm{s}$. Mean errors between calculated and observed heads averaged from 4 to 5 percent of the total relief of the water table in each flow system. Calculated heads in each system were sensitive to the specification of recharge rates and hydraulic conductivity of the uppermost coarse-grained stratified drift in each flow system. Calculated heads in the three-dimensional model of the complex flow system were also sensitive to the specification of the hydraulic conductivity of fine-grained sediments in the central part of the flow system (eastem Barnstable). These sensitivity analyses indicate that simulation of the flow systems might be improved if definition of recharge rates and hydraulic conductivity of coarse- and fine-grained sediments in each flow system were improved.

Particle tracking allows for delineation of the contributing area of a well because particles can be tracked from simulated areas of ground-water recharge to a simulated pumped well, thereby identifying the area contributing water to the well. Particle tracking is a relatively simple, yet quantitatively powerful, alternative to the construction of ground-water flow nets for delineation of contributing areas and sources of water to public-supply wells. The particle-tracking algorithm used in this investigation (MODPATH) tracks fluid particles on the basis of heads calculated by use of the U.S. Geological Survey modular ground-water-flow model. MODPATH is particularly useful because it tracks particles in either two- or three-dimensional ground-water flow simulations and does not require the specification of explicit time steps over which particle pathlines are determined.

Contributing areas were delineated for 2 hypothetical wells in the simple flow system and for 15 wells in the complex flow system. The location, size, and shape of contributing areas of simulated wells were shown to be affected by the proximity of the wells to aquifer-discharge boundaries and to other pumped wells, the vertical location of the well screen and pumping rate of each well, the distribution and rate of recharge to each aquifer, the hydraulic conductivity and the ratio of horizontal to vertical hydraulic conductivity of aquifer sediments, and the presence and continuity of discrete lenses of low hydraulic conductivity near each well. Contributing areas for wells in the complex flow system were not significantly affected by the value used for the conductance of streambed sediments or to the simulated depth of ponds or vertical hydraulic conductivity of pond-bottom sediments.

Results of the investigation indicate that the choice of either a two- or a three-dimensional model for delineation of contributing areas depends largely on the complexity of the flow system in which the well is simulated. Contributing areas delineated for the hypothetical wells in the simple flow system were not significantly different for the two- or three-dimensional models of the natural system and pumping rates greater than $0.25 \mathrm{Mgal} / \mathrm{d}$. For this relatively thin, single-layer aquifer with near-ideal boundary conditions, the use of a three-dimensional model to delineate contributing areas to supply wells may not be warranted. Several of the contributing areas delineated by use of the threedimensional model of the complex flow system and by use of the three-dimensional model of the simple flow system for hypothetical conditions, however, did not conform to simple ellipsoidal shapes that are typically delineated by use of two-dimensional analytical and numerical modeling techniques, included discontinuous areas of the water table, and did not surround the wells. Because two-dimensional areal models do not account for vertical flow, they cannot adequately represent many of the hydrogeologic and well-design variables that were shown to complicate the delineation of contributing areas in these systems, including the presence and continuity of discrete lenses of low hydraulic conductivity, ratios of horizontal to vertical hydraulic conductivity greater than the stratified-drift aquifers, shallow streams, partially penetrating supply wells, low (less than about $0.1 \mathrm{Mgal} / \mathrm{d}$ ) pumping rates, and spatial variability of recharge rates. Under these conditions, accurate delineation of contributing areas may require the use of a three-dimensional model.

Although particle traveltimes are useful for defining time-related contributing areas (or protection zones), they were shown to be highly dependent on model variables (hydraulic conductivity, the ratio of horizontal to vertical hydraulic conductivity, recharge rates, and porosity), depth of penetration of well screens, and choice of model. Because several of these parameters are rarely well defined, traveltime estimates can differ over a wide range. Furthermore, traveltime estimates determined by MODPATH account for neither 
hydrodynamic dispersion (because only the advective component of particle transport is simulated by MODPATH) nor the time required for a particle to travel through the unsaturated zone.

Particle tracking helped identify the source of water to simulated wells. In the simple flow system, precipitation recharge was the only source of water to the wells. The size of the contributing area of each well in this flow system is equal to the pumping rate of the well divided by the uniform recharge rate to the aquifer within the contributing areas. In the complex flow system, precipitation recharge, wastewater return flow, and pond throughflow were the predominant sources of water to the wells. Water from the head-dependent flux boundary at Wequaquet Lake was a minor source of water (less than 1 percent) to only one of the simulated wells in the simulation of the natural system and 1987 average daily pumping rates. Pond throughflow and wastewater retum flow accounted for up to 73 and 40 percent of well discharge, respectively. Contributing areas in the complex flow system are not linearly related to the pumping rate of each well because of the inclusion of ponds and pond contributing areas within the contributing areas of wells and because recharge rates to the aquifer are spatially variable. Elevated concentrations of nitrate (as nitrogen), an indicator of contamination from septic systems and wastewater-treatment facilities, were found in wells for which estimates of the volume of captured wastewater were large; this pattem indicates a correlation between the quality of water discharged by the wells and the simulated source of water to the wells.

Although particle tracking was shown to be of value in the delineation of contributing areas in simple and complex flow systems, the method requires a large amount of data, which must be collected and analyzed, especially for three-dimensional simulations. The amount of data that will be required for the development of accurate conceptual and numerical models of ground-water flow will depend in large part on the flow system in which the well is located and on the availability of hydrogeologic data at the beginning of the delineation study. The effort and, therefore, the cost that will be required for the delineation of the contributing area of a well will be proportional to the complexity of the flow system and the need for data collection and synthesis. Though the effort required for the development of the conceptual and numerical models of the complex flow system was greater than that required for the simple flow system, contributing areas were delineated for 15 wells in the complex flow system but for only 2 wells in the simple flow system.

Several limitations of the method used affect the accuracy with which a contributing area can be defined. These limitations include those caused by uncertainty in the definition of boundary conditions, stresses, and model parameters; limitations caused by discretization of the flow system by a finite-difference grid; and limitations in the data base used for model calibration. Furthermore, certain limitations are caused by the underlying assumptions of the numerical-model and particle-tracking algorithms themselves. Incorrectly defined boundary conditions and stresses that might have affected the delineation of contributing areas in these flow systems include the interface between freshwater and saltwater, the distribution and rate of recharge to the flow systems, and the head and conductance terms specified for simulated streams and Wequaquet Lake. Limitations caused by uncertainty in model hydraulic parameters arise because aquifer properties typically are only estimates of the true values and because these parameters commonly are known at only a few sites in the aquifer and must be extrapolated to areas of the model for which no data are available.

The discretization used in a ground-water-flow model affects (1) the level of detail at which hydrogeologic and system boundaries can be represented, (2) the accuracy of velocity calculations, and (3) the ability to represent internal boundary sinks accurately. A discretization that may be adequate for assessing regional water-supply concerns may not be adequate for a pathline analysis because velocity computations made by MODPATH are affected by the degree to which internal boundaries are represented. Contributing areas delineated for hypothetical wells in the simple flow system were unaffected by the scale of discretization of internal boundary sinks because the only sinks simulated by the two- or three-dimensional models were supply wells that captured all water flowing into the cells in which they were located. Contributing areas of several wells in the complex flow system were affected by weak internal boundary sinks; weak internal boundary sinks affected contributing areas delineated by use of the two-dimensional model more than they did those delineated by use of the three-dimensional model. This difference results from the fact that the single-layer model does not 
adequately represent the vertical location of discharge to the weak sinks at a small enough scale; vertical discretization of the flow system that includes a better representation of the screened interval of supply wells and of the head-dependent flux boundaries at streams and Wequaquet Lake, such as is provided by the threedimensional model, is required for improved delineation of contributing areas of wells in the complex flow system. Even with the limitations described above, however, accurate flow simulation coupled with particle tracking provides a technically rigorous and defensible means of delineating contributing areas of supply wells for the purpose of wellhead protection.

\section{REFERENCES CITED}

Allen, W.B., Hahn, G.W., and Brackley, R.A., 1966, Availability of ground water, upper Pawcatuck River basin, Rhode Island: U.S. Geological Survey Water-Supply Paper 1821, $66 \mathrm{p}$.

Aquifer Assessment Committee, Cape Cod Aquifer Management Project, 1988, Evaluation of approaches to determine recharge areas for public-supply wells, in Zoto, G.A., and Gallagher, Tara, eds., The Cape Cod Aquifer Management Project Final Report: Boston, Mass., Massachusetts Department of Environmental Protection, p. F1-F4.

Bair, E.S., Sheets, R.A., and Eberts, S.M., 1990, Particletracking analysis of flow paths and traveltimes from hypothetical spill sites within the capture area of a wellfield: Ground Water, v., 28, no. 6, p. 884-892.

Bair, E.S., Springer, A.E., and Roadcap, G.S., 1991, Delineation of traveltime-related capture areas of wells using analytical flow models and particle-tracking analysis: Ground Water, v. 29, no. 3, p. 387-397.

Barlow, P.M., 1989a, Delineation of contributing areas to public supply wells in stratified glacial-drift aquifers, in Proceedings of the Conference on Protecting Ground Water from the Bottom Up-Local Responses to Wellhead Protection, Danvers, Massachusetts, October 2-3, 1989: Oklahoma City, Okla., Underground Injection Practices Council Research Foundation, p. 145-164.

$1989 \mathrm{~b}$, Determination of aquifer properties from a thermal tracer experiment: Eos, v. 70, no. 15, p. 327.

Brown, R.H., 1963, The cone of depression and the area of diversion around a discharging well in an infinite strip aquifer subject to uniform recharge, in Bentall, Ray, compiler, Shortcuts and special problems in aquifer tests: U.S. Geological Survey Water-Supply Paper 1545C, p. C69-C85.
Buxton, H.T., Reilly, T.E., Pollock, D.W., and Smolensky. D.A., 1991, Particle tracking analysis of recharge areas on Long Island, New York: Ground Water, v. 29, no. 1, p. 63-71.

Cambareri, T.C., 1986, Hydrogeology and hydrochemistry of a sewage effluent plume in the Barnstable outwash of the Cape Cod aquifer, Hyannis, Massachusetts: Amherst, Mass., University of Massachusetts, unpublished Master's thesis, $130 \mathrm{p}$.

Davis, S.N., and DeWeist, R.J.M., 1966, Hydrogeology: New York, John Wiley and Sons, 463 p.

Dickerman, D.C., 1984, Aquifer tests in the stratified drift, Chipuxet River basin, Rhode Island: U.S. Geological Survey Water-Resources Investigations Report 83-4231, $39 \mathrm{p}$.

Edson, D.F., 1989, Aquifer protection through large scale computer modeling, in Proceedings of the Conference on Protecting Ground Water from the Bottom UpLocal Responses to Wellhead Protection, Danvers, Massachusetts, October 2-3, 1989: Oklahoma City, Okla., Underground Injection Practices Council Research Foundation, p. 119-121.

Farnsworth, R.K., Thompson, E.S., and Peck, E.L., 1982, Evaporation atlas for the contiguous 48 United States: National Oceanic and Atmospheric Administration Technical Report NWS 33, 26 p.

Freeze, R.A., and Cherry, J.A., 1979, Groundwater: Englewood Cliffs, N.J., Prentice-Hall, 604 p.

Frimpter, M.H., and Gay, F.B., 1979, Chemical quality of ground water on Cape Cod. Massachusetts: U.S. Geological Survey Water-Resources Investigations Report $79-65,11 \mathrm{p}$.

Garabedian, S.P., 1987, Large-scale dispersive transport in aquifers-ficld experiments and reactive transport theory: Cambridge, Mass., Massachusetts Institute of Technology, Ph.D. dissertation, 290 p.

Garabedian, S.P., and Konikow, L.F., 1983, Front-tracking model for convective transport in flowing ground water: U.S. Geological Survey Water-Resources Investigations Report 83-4034, 55 p.

Griswold, W.J., and Donohue, J.J., IV, 1989, Determining the area of contribution to a wellfield - A case study and methodology for wellhead protection, in Proceedings of the Conference on Protecting Ground Water from the Bottom Up_Local Responses to Wellhead Protection, Danvers, Massachusetts, October 2-3, 1989: Oklahoma City, Okla., Underground Injection Practices Council Research Foundation, p. 123-136.

Guswa, J.H., and LeBlanc, D.R., 1985, Digital models of ground-water flow in the Cape Cod aquifer system, Massachusetts: U.S. Geological Survey Water-Supply Paper $2209,112 \mathrm{p}$. 
Guswa, J.H., and Londquist, C.J., 1976, Potential for development of ground water at a test site near Truro, Massachusetts: U.S. Geological Survey Open-File Report 76614,22 p.

Heijde, Paul van der, and Beljin, M.S., 1988, Model assessment for delineating wellhead protection areas: Washington, D.C., U.S. Environmental Protection Agency, Office of Ground-Water Protection, 271 p.

Helsel, D.R., and Hirsch, R.M., 1992, Statistical methods in water resources: Amsterdam, Holland, Elsevier, 522 p.

Horsley, S.W., 1983, Delineating zones of contribution for public supply wells to protect groundwater, in Proceedings of the Eastern Regional Conference on Groundwater Management, Orlando, Florida, October 30November 2, 1983: Dublin, Ohio, National Water Well Association, p. 366-389.

Javandel, Iraj, and Tsang, C.F., 1986, Capture-zone type curves-a tool for aquifer cleanup: Ground Water, v. 24, no. 5, p. 616-625.

Keeley, J.F., and Tsang, C.F., 1983, Velocity plots and capture zones of pumping centers for ground-water investigations: Ground Water, v. 21, no. 6, p. 701-714.

Konikow, L.F., and Bredehoeft, J.D., 1978, Computer model of two-dimensional solute transport and dispersion in ground water: U.S. Geological Survey Techniques of Water-Resources Investigations, book 7, chap. C2, 90 p.

LeBlanc, D.R., Garabedian, S.P., Quadri, R.D., Morin, R.H., Teasdale, W.E., and Paillet, F.L., 1988, Hydrogeologic controls on solute transport in a plume of sewage-contaminated ground water, in Ragone, S.E., ed., Proceedings of the second technical meeting, Cape Cod, Massachusetts, October 21-25, 1985, U.S. Geological Survey Program on Toxic Waste-Ground-water Contamination: U.S. Geological Survey Open-File Report $86-481$, p. B-7 to B-12.

LeBlanc, D.R., Guswa, J.H., Frimpter, M.H., and Londquist, C.J., 1986, Ground-water resources of Cape Cod, Massachusetts: U.S. Geological Survey Hydrologic Investigations Atlas HA-692, 4 sheets.

Lee, K.H.L., and Wilson, J.L., 1986, Pollution capture zones for pumping wells in aquifers with ambient flow: Eos, v. 67 , no. 40, p. 966.

Linderfelt, W.R., Leppert, S.C., and Wilson, J.L., 1989, Capture zones for wellhead protection-effect of time dependent pumping, saturated thickness, and parameter uncertainty: Eos, v. 70, no. 43, p. 1079.

Lindner, J.B., and Reilly, T.E., 1983, Analysis of three tests of the unconfined aquifer in Southern Nassau County, Long Island, New York: U.S. Geological Survey WaterResources Investigations Report 82-4021, 46 p.
Mandle, R.J., and Kontis, A.L., 1986, Directions and rates of ground-water movement in the vicinity of Kesterson Reservoir, San Joaquin Valley, California: U.S. Geological Survey Water-Resources Investigations Report 864196,57 p.

Marsily, Ghislain de, 1986, Quantitative hydrogeology: Orlando, Fla., Academic Press, 440 p.

Mazzaferro, D.L., 1989, Estimation of the recharge area of a pumped, stratified-drift aquifer in Connecticut by simulation modeling: U.S. Geological Survey WaterResources Investigations Report 87-4124, 100 p.

McCann, J.A., 1969, An inventory of the ponds, lakes, and reservoirs of Massachusetts, Barnstable County: Amherst, Mass., Water Resources Research Center, $102 \mathrm{p}$.

McClymonds, N.E., and Franke, O.L., 1972, Water-transmitting properties of aquifers on Long Island, New York: U.S. Geological Survey Professional Paper 627-E, 24 p.

McDonald, M.G., and Harbaugh, A.W., 1988, A modular three-dimensional finite-difference ground-water-flow model: U.S. Geological Survey Techniques of WaterResources Investigations, book 6, chap. A1, 586 p.

Meinzer, O.E., 1923, Outline of ground-water hydrology with definitions: U.S. Geological Survey Water-Supply Paper $494,71 \mathrm{p}$.

Morris, D.A., and Johnson, A.I., 1967, Summary of hydrologic and physical properties of rock and soil materials as analyzed by the hydrologic laboratory of the U.S. Geological Survey, 1948-60: U.S. Geological Survey Water-Supply Paper 1839-D, 42 p.

Morrissey, D.J., 1989, Estimation of the recharge area contributing water to a pumped well in a glacial-drift, rivervalley aquifer: U.S. Geological Survey Water-Supply Paper 2338, $41 \mathrm{p}$.

Neuman, S.P., 1974, Effect of partial penetration on flow in unconfined aquifers considering delayed gravity response: Water Resources Research, v. 10, no. 2 , p. 303-312.

Newsom, J.M., and Wilson, J.L., 1988, Flow of ground water to a well near a stream--effect of ambient ground-water flow direction: Ground Water, v. 26, no. 6, p. 703-711.

Oldale, R.N., 1974a, Geologic map of the Dennis quadrangle, Barnstable County, Cape Cod, Massachusetts: U.S. Geological Survey Geologic Quadrangle Map GQ-1114, scale 1:24,000.

1974b, Geologic map of the Hyannis quadrangle, Barnstable County, Cape Cod, Massachusetts: U.S. Geological Survey Geologic Quadrangle Map GQ-1158, scale $1: 24,000$.

Oldale, R.N., and Barlow, R.A., 1986, Geologic map of Cape Cod and the Islands, Massachusetts: U.S. Geological Survey Miscellaneous Investigations Series Map I-1763, scale 1:100,000. 
Olimpio, J.C., and de Lima, Virginia, 1984, Ground-water resources of the Mattapoisett River valley, Plymouth County, Massachusetts: U.S. Geological Survey WaterResources Investigations Report 84-4043, 88 p.

Perlmutter, N.M., and Lieber, Maxim, 1970, Dispersal of plating wastes and sewage contaminants in ground water and surface water, South Farmingdale-Massapequa area, Nassau County, New York: U.S. Geological Survey Water-Supply Paper 1879-G, 67 p.

Pollock, D.W., 1988, Semianalytical computation of pathlines for finite-difference models: Ground Water, v. 26 , no. 6, p. $743-750$.

1989 , Documentation of computer programs to compute and display pathlines using results from the U.S. Geological Survey modular three-dimensional finite-difference ground-water-flow model: U.S. Geological Survey Open-File Report 89-381, 188 p.

Prickett, T.A., Naymik, T.G., and Lonnquist, C.G., 1981, A "random-walk" solute transport model for selected ground-water quality evaluations: Illinois State Water Survey Bulletin 65, 103 p.

Prince, K.R., and Schneider, B.J., 1989, Estimation of hydraulic conductivity of the upper glacial and Magothy aquifers at East Meadow, New York, by use of aquifer tests: U.S. Geological Survey Water-Resources Investigations Report 87-4211, 43 p.

Ramm, Dov, and Chazan, Dan, 1980, A mixed numerical analytical method for groundwater flow simulation: Water Resources Research, v. 16, no. 5, p. 871-880.

Reilly, T.E., 1978, Convective contaminant transport to pumping well: Journal of the Hydraulics Division, Proceedings of the American Society of Civil Engineers, $v$. 104, no. HY12, p. 1565-1575.

Richie, E.B., and Hoover, J.R., 1985, Numerical simulation of the convective transport of a noninteractive chemical through an unsaturated/saturated porous media: Transactions of the American Society of Agricultural Engineers, v. 28 , no. 6 , p. $1860-1866$.
Ryan, B.J., 1980, Cape Cod Aquifer, Cape Cod, Massachusetts: U.S. Geological Survey, Water-Resources Investigations Report 80-571, 23 p.

SEA Consultants, Inc., 1985, Groundwater and water resource protection plan Barnstable, Massachusetts: Boston, Mass., SEA Consultants, 185 p.

Shafer, J.M., 1987, Reverse pathline calculation of timerelated capture zones in nonuniform flow: Ground Water, v. 25 , no. 3 , p. 283-289.

Springer, A.E., and Bair, E.S., 1991, Comparison of methods used to delineate traveltime-related capture zones of wells in a stratified-drift buried-valley aquifer: Eos, v. 72 , no. 17 , p. 111.

Strahler, A.N., 1972, The environmental impact of ground water use on Cape Cod, Impact Study III: Orleans, Mass., Association for the Preservation of Cape Cod, $68 \mathrm{p}$.

1988, A geologist's view of Cape Cod: Garden City, N.Y., The Natural History Press, 115 p.

Theis, C.V., 1938, The significance and nature of the cone of depression in ground-water bodies: Economic Geology, v. 33 , no. 8 , p. $889-902$.

U.S. Environmental Protection Agency, 1987, Guidelines for delineation of wellhead protection areas: Washington, D.C., U.S. Environmental Protection Agency, Office of Ground-Water Protection, p. 4/1-4/32.

1990, WHPA - a modular semi-analytical model for the delineation of wellhead protection areas: Washington, D.C., U.S. Environmental Protection Agency, Office of Ground-Water Protection, 232 p.

Vecchioli, John, Hunn, J.D., and Aucott, W.R., 1989, Evaluation of methodology for delineation of protection zones around public-supply wells in west-central Florida: U.S. Geological Survey Water-Resources Investigations Report 88-4051, 36 p.

Wilson, J.L., 1986, Induced infiltration in aquifers with ambient flow: Eos, v. 67, no. 44, p. 966. 